The University of Southern Mississippi

The Aquila Digital Community

Dissertations

Spring 5-2010

\title{
The Italian Emigration of Modern Times: Relations Between Italy and the United States Concerning Emigration Policy, Diplomacy, and Anti-Immigrant Sentiment, 1870-1927
}

Patrizia Fama Stahle

University of Southern Mississippi

Follow this and additional works at: https://aquila.usm.edu/dissertations

Part of the Cultural History Commons, European History Commons, Political History Commons, Social History Commons, and the United States History Commons

\section{Recommended Citation}

Stahle, Patrizia Fama, "The Italian Emigration of Modern Times: Relations Between Italy and the United States Concerning Emigration Policy, Diplomacy, and Anti-Immigrant Sentiment, 1870-1927" (2010).

Dissertations. 934.

https://aquila.usm.edu/dissertations/934

This Dissertation is brought to you for free and open access by The Aquila Digital Community. It has been accepted for inclusion in Dissertations by an authorized administrator of The Aquila Digital Community. For more information, please contact Joshua.Cromwell@usm.edu. 
The University of Southern Mississippi

THE ITALIAN EMIGRATION OF MODERN TIMES: RELATIONS

BETWEENITALY AND THE UNITED STATES CONCERNING

EMIGRATION POLICY,DIPLOMACY, AND ANTI-IMMIGRANT

SENTIMENT, 1870-1927

\author{
by \\ Patrizia Famá Stahle
}

\begin{abstract}
Dissertation Submitted to the Graduate School of The University of Southern Mississippi in Partial Fulfillment of the Requirements of the Degree of Doctor of Philosophy
\end{abstract}




\section{ABSTRACT}

THE ITALIAN EMIGRATION OF MODERN TIMES: RELATIONS BETWEEN

ITALY AND THE UNITED STATES CONCERNING EMIGRATION POLICY, DIPLOMACY, AND ANTI-IMMIGRANT SENTIMENT, 1870-1927

\section{by Patrizia Famà Stahle}

May 2010

In the late 1800s, the United States was the great destination of Italian emigrants. In North America, employers considered Italians industrious individuals, but held them in low esteem. Italian immigrants were seen as dangerous subversives, anarchists, cheap laborers who were always ready to accept jobs for lower wages. Indeed, numerous episodes of violence and even lynching of Italians occurred in the late nineteenth and early twentieth centuries in the United States. In most cases, the violence went unpunished by the local authorities. Such episodes of violence provoked a diplomatic controversy between Italy and the United States concerning treaty-guaranteed protection of foreign-born nationals on U.S. soil. The contention focused on the lack of jurisdiction by the federal government in the member states of the Union based on the separation of powers. The federal government took the position that there was no liability on its part for acts of mob violence, claiming that protection to aliens must be under the control of state governments. However, the federal government often found itself in an embarrassing position because of failure to comply with existing treaty obligations. 
The contention between Italy and the United States was never resolved in a satisfactory manner, except for payment of indemnities to the victims' families. However, long and patient diplomacy on the part of Italian representatives prompted the beginning of a movement in Congress for passage of a federal anti-lynching law aimed at protection of aliens who had treaty rights. Proposals submitted to Congress for a federal anti-lynching law were not successful because of constitutional issues, states' rights, and sectional prejudice. Italian diplomats protested vigorously the federal government's failure to comply with existing treaties. However, they adopted a realistic attitude of prudence and moderation, and made efforts to maintain good relations with the United States-except for the case of New Orleans which provoked a serious diplomatic crisis and national pride, culminating in Rome's recall of its ambassador. 
COPYRIGHT BY

PATRIZIA FAMÀ STAHLE

2010 


\section{ACKNOWLEDGEMENTS}

My dissertation committee was very helpful in providing guidance, knowledge, and encouragement for me to complete this study on diplomatic incidents that arose between Italy and the United States over a series of lynchings of Italian immigrant laborers in the late nineteenth and early twentieth centuries. The committee includes professors James "Pat" Smith, Orazio Ciccarelli, L. Margaret Barnett, Phyllis Jestice, and Kenneth McCarty. Each professor contributed to the completion of this project in a unique way. However, Dr. Ciccarelli and Dr. Smith both deserve special thanks. Dr. Ciccarelli provided guidance in the initial stage of my research and writing. He helped me to narrow my topic and to devise a good research design, and he advised me about which archives to explore. Most of all, he provided his own knowledge of Italian emigration history. Dr. Smith took over as dissertation committee chair during the final stage of this project. He provided dynamic guidance and leadership during the last months of rewriting, polishing, editing, sharpening the focus and improving the final product. I am most grateful to all committee members for all that I learned in their classes and especially for what each one of them taught me about the art of writing.

Many archivists and librarians have contributed to the success of my dissertation. I did my research in Rome, Italy; New York; Athens, Georgia, and Jacksonville, Florida. I would like to thank Dr. Rosaria Ruggeri, Dr. Andrea Edoardo Visone, and Fabrizio Federici of the Italian Foreign Ministry Diplomatic Archives (ASDMAE, Rome, Italy). I wish to thank the staff of the New York 
Center for Migration Studies; the librarians of the Public Library, Jacksonville, and Patrick Dunn of the Eureka, Nevada, Historical Library. I also wish to thank the librarians at the College of Coastal Georgia, where I have taught history fulltime for the past ten years: Ray Calvert, former Director of Libraries and Learning Resources; John Kissinger, Director of Library, Camden Center; Roberta Basenfelder, Duressa Pujat, Heather Brown, and especially Linda Kennedy whose expertise in U.S. government documents and connections at the Library of Congress, Washington, D.C., were instrumental in obtaining important State Department sources. I thank all of them for their patience, availability, and expertise.

Special thanks go to my friend and colleague Sharon Bartkovich, Associate Professor of English at the College of Coastal Georgia, for editing the manuscript. I am most grateful for the help that she extended to me in editing my work.

Finally, I am grateful to my husband, George, whose loving partnership made it possible for me to have an intellectually satisfying profession and a full and happy personal life. I also thank my children, George Arthur and Crystal Alexia, for firmly believing that I would finish my dissertation. Their loving support and faith in their mother helped through the bright and dark days of research and writing. 


\section{TABLE OF CONTENTS}

ABSTRACT ii

ACKNOWLEDGEMENTS. iv

CHAPTER

I. INTRODUCTION. 1

II. THE GREAT MIGRATION FROM THE ORIGINS TO THE CLOSURE OF THE AMERICAN GATES.

III. ITALIAN EMIGRATION LAWS AND POLICY FROM THE LIBERAL STATE TO THE FASCIST STATE.

IV. ANTI-ITALIAN SENTIMENT IN THE UNITED STATES: HARASSMENT, VIOLENCE, AND LYNHCING IN THE LATE 1800s..

V. MORE LYNCHING, VIOLENCE AND HARASSMENT IN THE EARLY 1900s.

VI. THE ITALIAN RESPONSE: THE PROBLEM OF PROTECTION OF ALIENS AND RELATIONS BETWEEN ITALY AND THE UNITED STATES.

VII. CONCLUSION. 


\section{CHAPTER I}

\section{INTRODUCTION}

By the late 1800s the United States was the greatest destination of Italian emigrants. The United States represented for them not only the promise of a brighter future but also the fragility of that dream. Italian immigrants were valued as a source of cheap, unskilled labor always ready to accept a job for lower wages than Americans. Thus, both American employers and workers looked down on them as an inferior race. In addition, Italians were stereotyped as dangerous subversives, anarchists, and troublemakers. Numerous episodes of violence and even lynching of Italians occurred in the late 1800s and early 1900 s in the United States. In most cases the violence went unpunished by the local authorities, regardless of the innocence or guilt of the victims. Italian diplomatic representatives protested vigorously the federal government's failure to protect Italian nationals working on U.S. soil, who were supposed to be protected by existing treaties. However, Italian diplomats usually adopted a realistic attitude of prudence and moderation and made efforts to maintain good relations between Washington and Rome--except for the New Orleans lynching of 1891, which provoked a serious diplomatic crisis and national pride in the Italian Parliament culminating in Rome's recall of its ambassador.

One of the most striking features of Italy's modern history is the great migration of the Italian people shortly after completion of the country's unification in 1871. Between 1876 and the onset of World War II, roughly twenty million emigrants left the Italian peninsula and the islands of Sicily and Sardinia, 
representing 10 percent of emigrants throughout the world during that period of time. The majority of Italian emigrants were poor, unskilled, landless peasants or owners of tiny parcels of land. The search for wages scattered them more than it did any other European emigrants of that era. Almost half stayed in Europe, while approximately one third went to North America, and smaller groups went to Australia or Africa. The majority of Italian emigrants were men who found work in several sectors--construction, mining, industry, and agriculture. ${ }^{1}$

In the last two centuries of Italian history, there has not been a phenomenon of such magnitude and persistence as the continuous migratory movement. While the history of Italian emigration has often been absent from books of modern Italian history, scholars of emigration have attempted to study the migratory flux and the reasons why millions of Italians left their homeland to start a new life elsewhere. They have pointed out that emigration is not necessarily indicative of a state's embarrassing illness, but is a normal social phenomenon that has continuously occurred in history. Indeed, in an era of globalization, Italy has recently become a receiving country, a land of immigrants rather than a land of emigrants. ${ }^{2}$

Prejudice, however, has often relegated the figure of the emigrant to the fringe of society, destined to be removed, forgotten, and ignored in narratives of national histories. Yet, scholars of Italian emigration history have made an

\footnotetext{
${ }^{1}$ Denis Mack Smith, Italy: A Modern History (1959; repr., Ann Arbor: University of Michigan Press, 1969), 238.

${ }^{2}$ Ferdinand Braudel, The Mediterranean and the Mediterranean World in the Age of Philip II (New York: Harper \& Row, 1966), 2 volumes.
} 
attempt to reintroduce the emigrant into mainstream history. ${ }^{3}$ Undoubtedly, emigration is a difficult topic, connected as it is to a vast array of questions concerning geographical-territorial mobility, a great variety of jobs and trades, different reasons for leaving the homeland, various patterns of adaptation in the receiving countries, and the issue of mixed descent that spread Italians abroad during a long migratory diaspora. ${ }^{4}$

It has been estimated that approximately sixty million Italians or individuals of Italian descent live abroad today, almost as many as are currently living in Italy. It is interesting to note that a study conducted to celebrate the centennial of the Italian unification revealed that, during that hundred years, as many as twenty-six million Italians left (the first census taken after completion of unification, in 1871, found that the population of the newly forged Kingdom of Italy amounted to twenty-six million). Although emigration cannot be reduced to one unique model for each region or each generation in modern Italian history, such large figures indicate that mobility permeated modern Italian society and that, beyond individual and regional differences, many children of the Italian peninsula left to escape poverty and to better their lives. Moreover, such large figures point out that the history of Italian emigration should be included in mainstream national history as these "lost children" must have had an impact on the development of Italian history and on the spread of Italian culture abroad.

\footnotetext{
${ }^{3}$ Donna Gabaccia, "Italian History and gli Italiani nel Mondo, Part I,” Journal of Modern Italian Studies, vol. 2, no. 1 (1997): 45-66.

${ }^{4}$ Ibid., 47-49
} 
The elusive nature of emigration as a historical phenomenon, however, makes it hard to restore the emigrant to his or her rightful place in Italian history.

Undoubtedly, several factors caused such a dramatic emigration phenomenon, including poverty, scarcity of labor, and agrarian crises. There was no region of the Italian peninsula where individual laborers were loath to go. Emigrants went wherever work could be found, but found European and American labor markets the most open and welcoming. ${ }^{5}$

Although there were no significant differences between northern and southern emigration from the Italian peninsula, the United States became a promised land especially for southern Italians who had suffered greatly because of heavy taxation, modest income, debts, evictions, and foreclosures. In North America southern Italian immigrants found work at the very bottom of the labor market: in the mines, railroads, and construction industry. However, the pay was good, and they could send remittances back home to their wives to pay old debts, buy a parcel of land, or provide for a daughter's dowry. ${ }^{6}$

The emigration phenomenon had a profound impact on Italian society. Economically, such a tremendous movement brought a great deal of wealth to the Italian peninsula. Not only did the emigrants send money to their families, thus ameliorating their standard of living, but also the continuous influx of foreign currency helped finance industrialization in Italy in the early twentieth century.

\footnotetext{
${ }^{5}$ Robert Foerster, The Italian Emigration of Our Times (1919; repr., Cambridge: Harvard University Press, 1924), 3.

${ }^{6}$ Ercole Sori, L'emigrazione italiana dall'unità alla seconda guerra mondiale (Bologna: Il Mulino, 1979), 83-84.
} 
Also, the Italians abroad always desired products from their country of origin, thus stimulating exports. Furthermore, the remittances sent by the emigrants to Italy were in part deposited in post offices or invested in government bonds. Hence, the availability of money allowed the Italian government to divert emigrants' savings to the development of the northern "industrial triangle." 7

With men leaving to search for their livelihood elsewhere, society underwent feminization. In some areas, entire towns were denuded of people. The cycle of life changed. Young people tended to marry earlier and, after marriage, men left, investing their wives' dowries in their journey across the ocean. In spite of the distance, husbands and wives could share successes and failures, and wives could be entrusted with savings sent by their emigrant husbands. Remittances represented the main support of the family itself but, because of the distance and long periods of separation, the number of births diminished. The family as an institution, however, managed to survive. ${ }^{8}$

The emigration of millions of citizens engendered heated debates about the phenomenon and what it meant for Italian society, economy, and politics. The political debates concerning emigration and the subsequent laws and policies implemented were expressions of every different political and economic ideology present in Italy from the completion of unification to at least 1888.

The majority of politicians in parliament opposed free emigration while a minority argued spiritedly in its favor. Defenders of emigration argued that it

\footnotetext{
${ }^{7}$ Gino Arias, La Questione Meridionale (Rome: Editori Riuniti, 1970), 420.

${ }^{8}$ Giorgio Mortara, Le popolazioni delle grandi città italiane (Turin: Unione Tipografica Editrice Torinese, 1908).
} 
helped to maintain social order, eased the pressure of overpopulation, and created foreign markets for national goods. Opponents feared that the loss of manpower would cause labor shortages and would weaken the institution of the family.

During the 1880s, official opposition to emigration subsided as colonial fever gripped most European nations. The debate in Italy shifted from how emigration could be most effectively limited to how it could be more profitably utilized. Should emigration be spontaneous or state-directed? Should emigrants be left free to emigrate wherever they wished, or should they be made a tool of Italian imperial policy? In the 1880 s and 1890 s, the Italian government chose the latter option and committed the nation to a series of fruitless wars that ended ruinously and did little to alter the emigrants' preference for the Americas. It was during the tenure of Prime Minister Francesco Crispi (P.M. 1887-1891; 18931896), a strong proponent of state-directed emigration to Africa, that the first important emigration law was passed on December 30, 1888. Although restrictive, the law of 1888 represented an effort by the state to regulate the activities of agents and navigation companies, to regulate the terms of transportation contracts, and especially to recognize that emigrants must be protected. The law, however, reflected the contradictions of the times and the lack of consensus about whether emigration was good or bad for the country. ${ }^{9}$

Following a humiliating defeat at Adowa, Ethiopia, on March 1, 1896, Crispi fell from power, and the liberals in the Italian Parliament revived the

\footnotetext{
${ }^{9}$ Ferdinando Manzotti, La polemica sull'emigrazione nell'Italia unita fino alla prima guerra mondiale (1962; repr., Milan: Società Editrice Dante Alighieri,1969), 81-83; Gianfausto Rosoli, ed., Un secolo di emigrazione italiana, 1876-1976 (Rome: Centro Studi Emigrazione, 1978), 254-255.
} 
argument for the Americas. Also, in the meantime, it became apparent that the emigrants' remittances from the Americas were crucial for the economy, whereas Africa was a drain on the economy. The result was passage of the law of 1901, a ground-breaking law whose main aim was to protect the emigrant. The most important feature of the law was the creation of the new office of Commissioner General of Emigration (CGE), located in the Ministry of Foreign Affairs rather than in the Ministry of the Interior, which traditionally had had jurisdiction over emigration matters. The Commissioner General of Emigration was entrusted with the responsibility for protecting emigrants from abuse and cruel exploitation rather than policing their activities as the Ministry of the Interior had previously done. The establishment of the CGE represented an important accomplishment in dealing with the phenomenon of .emigration. Indeed, in spite of a few limitations and shortcomings, the law of 1901 can be considered a true landmark in the history of Italian emigration. ${ }^{10}$

During the interwar period, however, nationalist, imperialist politicians dominated Italian foreign policy and opened the way for the rise of Benito Mussolini to power in 1922. Eventually, it was Mussolini, the Duce of Fascist Italy, who decided to abolish the CGE and replace it with the General Bureau of Italians Abroad (Direzione Generale Italiani all' Estero) in 1927. Arguing that Italy was a country of superabundant energy, Mussolini chose to call emigrants "Italians abroad." He also tried to emphasize the positive aspects of emigration, to raise the general esteem of Italians abroad, to ameliorate the overall image of

\footnotetext{
${ }^{10}$ Foester, The Italian Emigration of Our Times, 477; Rosoli, Un secolo di emigrazione italiana, 258; Manzotti, La polemica sull' emigrazione, 156.
} 
Italy, and to spread Italian culture in the world. He emphasized the need to regulate and control the emigration flux and especially to make it temporary and not permanent. Nonetheless, what Mussolini and his associates did for the emigrants was too little too late. ${ }^{11}$

Over the course of several decades, liberal governments issued laws that were increasingly supportive of emigration and that provided greater protection for emigrants. These laws grew out of the gradual acceptance of the notion that emigrants were citizens, that they were the responsibility of the state and must, therefore, be protected at every phase of the migratory process. The fascist state embraced this policy, but unlike liberal governments, sought to utilize its citizens abroad to advance Italy's prestige and interests and to fuel nationalistic fervor. To achieve these goals, Mussolini convened an International Conference of Emigration and Immigration in 1924 and established a financial Institute of Italian Workers Abroad and also Fasci all' Estero (Fascist clubs abroad). A whole network of Fascist clubs outside Italy was established soon after Mussolini's march on Rome (October 28, 1922). The purpose for these clubs was to export fascist doctrine, to implement a spiritual and cultural penetration of other countries, and especially to stimulate a sense of national sentiment in Italian emigrants. Mussolini did not want to allow Italians abroad to be assimilated into alien cultures. Rather, he wanted to utilize the emigrants to enhance the prestige of Italy abroad as well as to diffuse Italian culture and civilization. ${ }^{12}$

\footnotetext{
${ }^{11}$ Philip Cannistraro and Gianfausto Rosoli, "Fascist Emigration Policy in the 1920s: An Interpretative Framework,” International Migration Review, vol. 13, no. 4 (1979): 673-692.

${ }^{12}$ Alan Cassels, Mussolini’s Early Diplomacy (Princeton: Princeton University Press, 1970), 195.
} 
The emigration policy conducted by the Fascist regime differed from the policies enacted by the liberal governments that preceded it in that it attempted to enhance the economic and political value of the emigrant. Fascist emigration policy was consistent with a larger political centralization trend as well as with the ideology of the Fascist regime. For example, the office of Commissioner General of Emigration was abolished not because of the desire to eliminate an office that had become pretty much autonomous, but as a result of a general policy of political centralization, including pursuit of demographic growth and control and regulation of the migratory flux. Political centralization, demographic exaltation, and control of emigration were all components rooted in fascist ideology and the pursuit of national prestige, the spread of Italianness, and preservation of national sentiment abroad among Italian nationals. ${ }^{13}$

Mussolini's vision of emigration and emigrants clashed with the growing protectionist and anti-immigration legislation being enacted in many countries. Among them was the United States, which in 1921 and 1924 enacted laws that effectively closed its borders to emigrants from southern and eastern Europe. In fact, after passage of the 1921 law, Italian emigration to the United States was reduced from 408,104 in 1920 to 114,912 in 1921 and to 120,501 in 1924. After 1924, the number of Italian emigrants coming to the United States continued to fluctuate as follows: 96,435 in $1925 ; 117,422$ in $1926 ; 125,423$ in $1927 .{ }^{14}$

The legislation of the 1920s was the culmination of decades long, deeplyfelt anti-Italian sentiment that portrayed Italians as generally hard-working and

\footnotetext{
${ }^{13}$ Rosoli, Un secolo di emigrazione italiana, 259-260.

${ }^{14}$ Ibid., 346.
} 
industrious and as a very dependable source of cheap labor, but also as dangerous subversives prone to trouble making. This contradictory image of the Italian immigrant, rooted both in deep xenophobia and economic conflict, produced waves of violence and numerous cases of lynching in the late nineteenth and early twentieth centuries. In most cases, violence, harassment, and lynchings went unpunished by the local authorities, regardless of the innocence or guilt of the victims. Yet, Mussolini protested the reduced quotas, even though neither he nor the liberals had succeeded in winning effective antilynching laws to protect the emigrants.

Italian emigration to the Americas, mostly to the United States, went through three phases. From 1876 to 1890 , the majority went to Argentina; then until 1897 Argentina and Brazil were almost equally favored by emigrants; from 1898 to the outbreak of World War I and then the interwar period, the United States became the chief outlet for Italian emigration. This emigration continued until legislative restrictions checked that current and forced the emigrants to seek South American countries again.

Why were Italians disliked or even hated to the point of provoking violence and lynching that went unpunished? What provoked such episodes of violence in the United States? What kind of reactions, if any, were there on the part of Italian diplomats in the United States? This study will examine episodes of lynchings of Italians in Eureka, Nevada (1879); Vicksburg, Mississippi (1886); Louisville, Kentucky (1889); New Orleans, Louisiana (1891); Seattle, Washington (1892); Denver, Colorado (1893); Walsenburg, Colorado (1895); Hahnville, Louisiana, 
(1896); Tallulah, Louisiana (1899); Erwin, Mississippi (1901); Ashdown, Arkansas (1901); Davis, West Virginia (1903); and Tampa, Florida (1910). These episodes were emblematic of the violence, racism, and xenophobia to which Italian nationals were subjected in the United States during that period. These cases of violence against individuals of Italian origin strained relations between Italy and the United States and opened the way to various and complex diplomatic incidents. In particular, the 1891 lynching of New Orleans so soured relations between the two countries that there were rumors of war, culminating in Rome's recall of its ambassador.

The Italian government's frustration with Washington was based on the claim that the United States had failed to comply with the 26 February 1871 treaty between the two nations, which contained a reciprocity clause providing for mutual protection of foreign-born citizens as well as equal treatment of foreignborn and native-born individuals residing in different states of the Union. Based on the treaty, foreign-born and native-born were entitled to equal treatment. However, Washington responded that the acts of violence against Italians were outside its jurisdiction to investigate. It was the responsibility of the state, not the national authorities, to conduct an investigation and bring the guilty parties--if any were found--to justice. Federal constitutional delegation of powers to states, an important feature of the U.S. Constitution, presented a dilemma to foreign-born citizens in that it made it very difficult to find an acceptable solution to the problems caused by ethnic hatred and violence. It was a contradiction in terms that the President of the United States, who indeed represented all of the states 
of the Union in relations with foreign countries, did not have the power to interfere with the individual states beyond putting pressure on governors or the local police force in cases of violence perpetrated against foreign-born nationals. There was a fundamental conflict between the right of the single states to manage their own affairs and the responsibility of the U.S. federal government to comply with international treaties that guaranteed the right of foreign-born citizens to receive mutual protection as provided by the reciprocity clause. ${ }^{15}$ Resolving the diplomatic crisis between the Italian and the United States governments depended upon compliance with existing treaties, protection of citizens (both Italian nationals and naturalized citizens), and compensation of victims' families by awarding payment of an indemnity, the so-called "blood price."

The United States government took the position that there was no liability on its part for acts of mob violence, that protection of aliens residing in the United States must rest with the local authorities, and that criminal prosecution for any acts of mob violence was also the responsibility of the state authorities. Furthermore, in case of the government's paying indemnities for acts of violence, payment was made merely as an act of charity and liability was denied. This attitude placed the United States in an embarrassing position because of the failure of the federal government to comply with existing treaty obligations. In fact, the contention between Washington and Rome provoked a movement in the U.S. Congress advocating passage of an anti-lynching federal law to protect

\footnotetext{
${ }^{15}$ ASDMAE, Trattati e Convenzioni fra il Regno d'Italia e i governi esteri, vol. IV (1 January 1870 to 1 January 1873) (Rome: Tipografia Nazionale di G. Bertero, 1874), 144-155; United States-Italy, Treaty of Commerce and Navigation (February 26, 1871) in Malloy’s Treaties, 1:969.
} 
aliens from mob violence. No fewer than four presidents--Benjamin Harrison, William McKinley, Theodore Roosevelt and William Howard Taft--suggested a federal law providing for punishment of crimes against aliens in violation of the guarantees of the treaties. However, proponents of such laws found strong opposition in Congress. The main objection to the enactment of such legislation was that it would grant to an alien better rights than those of a citizen in the United States. Italian representatives in the United States protested the failure of the U.S. Congress to confer jurisdiction in cases of mob violence on the federal courts and stated that, until such power was conferred, the Italian government would have reason to complain of violation of the existing treaties and would continue to hold the federal government responsible for mob violence. Proposals submitted to the U.S. Congress for anti-lynching legislation calling for federal jurisdiction over violence against either native-born or foreign-born victims never became law. ${ }^{16}$

In recent years, scholars have produced numerous studies about white mob violence against African Americans, but the lynching of whites remains relatively neglected. The purpose of this study is to shed light on episodes of violence against individuals of Italian origin in the United States between 1879 and 1910; to analyze causes, motives, and characteristics of such mob attacks; and to assess the role of Italian diplomats in asserting the right of aliens to protection by the U.S. government according to existing treaties. Although the

\footnotetext{
${ }^{16}$ Charles H. Watson, "Need of Federal Legislation in Respect to Mob Violence in Cases of Lynching of Aliens," The Yale Law Journal, vol. 25, no.7 (May 1916): 561-581; David O. Walter, "Legislative Notes and Review Proposals for a Federal Anti-Lynching Law,” The American Political Science Review, vol. 28, no. 3 (June 1934): 436-442.
} 
contention between Rome and Washington was never resolved in a satisfactory manner except for payment of indemnities to the victims' families, long and patient diplomacy on the part of Italian representatives in the United States prompted the beginning of a movement in Congress in 1892, following the lynching of eleven Italians in New Orleans (14 March 1891), for passage of a much-needed federal anti-lynching law aimed at protection of aliens in accordance with treaty rights. Bills for this purpose were introduced in the Senate in 1893, 1899, and 1908, and in the House in 1900, 1902, 1903, 1905, and 1907. In 1922, the Dyer bill included a clause for the protection of aliens, adopting the form suggested in 1892. The Dyer bill failed, as did successive measures introduced in the 1920s when restrictive immigration laws curtailed the immigrant flux into the United States. As immigration to the United States subsided, so did anti-immigrant sentiment, xenophobia, and violence against aliens.

Undoubtedly, constitutional issues, states' rights, and racial prejudices were serious obstacles to the enactment of a federal anti-lynching law. The Italian government protested vigorously the failure of the U.S. government to comply with existing treaties, to protect aliens on U.S. soil adequately, and to confer jurisdiction on the federal courts in cases of mob violence. In general, however, Italian diplomats in the United States adopted a realistic attitude of prudence and moderation and, except for the case of New Orleans (which provoked a serious diplomatic crisis and national pride, culminating in Rome's recall of its ambassador), they tried to maintain good relations between Washington and Rome. In fact, continued emigration and its value to Italian 
society as a "safety valve" and as a source of foreign currency and capital accumulation took precedence over protecting emigrants from American lawlessness. The Italian government was powerless to force protection through U.S. legislation. Yet, it refrained from cutting off emigration to the United States-a place where emigrants were at considerable risk because of racism, economic resentment, and the American habits of vigilantism and lynching. 


\section{CHAPTER II}

THE GREAT MIGRATION FROM ITS ORIGINS TO THE CLOSURE OF THE AMERICAN GATES

By the late 1800 s the United States was the favorite destination of Italian emigrants. The United States represented for them the promise of a brighter future but also the fragility of that dream. In fact, Italian immigrants were often looked down upon and subjected to discrimination and even lynching. Thus, violence, harassment, and discrimination that Italian emigrants suffered when they settled in the United States challenged Italian legislators and diplomats at a time when they had to deal with post-unification problems, economic issues, agrarian crises, and lack of resources that prompted the children of Italy to leave their country to make a living elsewhere. The economic impetus that drove emigration also promoted a strong bent toward caution and pragmatism within the Italian government in its diplomatic dealings with the United States over the protection of Italian workers against abuse.

The first great migratory wave of contemporary Italy went on between 1880 and 1930. During those fifty years, more than 17 million men and women left their homeland in order to make a living elsewhere. Some left and were able to come back; most never returned. These individuals were workers, artisans, and above all peasants. Mobility was not an unusual phenomenon; individuals had moved frequently in the previous centuries. However, there were some new elements in this modern "great migration"--magnitude of numbers, fast rate of departures, and choice of new lands across the Atlantic. 
Undoubtedly, poverty, misery, and the condition of Italian agriculture were important factors in originating such a huge migratory wave, but there were also other elements, most notably an international labor market that was becoming increasingly complex. However, the transfer of labor from the agricultural to the industrial sector was not continuous or even linear; hence, agriculture never ceased to offer opportunities for a population that was in crisis.

Indeed, a look at the first decade of the nineteenth century can be most enlightening for an understanding of emigration. Two major areas in Italy attracted seasonal migrants--the western part of the Po River Valley (Piedmont and Lombardy), where about 50,000 laborers went to work from Piedmont, the Appennines, and the Alps (including 4,000 from Switzerland and Bavaria); and the coastal areas of central Italy, including the Tuscan Maremma and the Roman countryside, where laborers converged from the Appennines, Umbria, Abruzzi, and Calabria. ${ }^{1}$ In addition, Piedmont exported laborers to the Dolomites Alps, Venetia, and Austria-Hungary. ${ }^{2}$ There was no region of the peninsula from which young laborers would not depart for seasonal work of various lengths, walking hundreds of miles and sleeping under the sky. Such migratory phenomenon has been called "the major system of temporary migration in western Europe."3

Was there a difference between internal migration and emigration abroad? An inquiry conducted during the Napoleonic era suggests that there was no

\footnotetext{
${ }^{1}$ Ian Lucassen, Migrant Labor in Europe 1600-1900 (London: Croon Helm, 1987), $234-244$.

${ }^{2}$ Ibid., p.260. Lucasssen has analyzed an inquiry conducted during the Napoleonic era aimed at verifying the reasons why young men did not answer a call for conscription. The main result was an enlightening analysis of migratory movements in Italy and other parts of Europe under Napoleon.

${ }^{3}$ Leslie Page Moch, Moving Europeans: Migration in Western Europe since 1650 (Bloomington: Indiana University Press, 1992), 78.
} 
difference, that the usual division that scholars have been drawing between domestic and external migration is an artificial one, for laborers were willing to go wherever work could be found, be it Austria-Hungary or Switzerland or the Roman countryside. While a line of division between domestic and foreign migration could be artificially drawn, the motives for departure usually can be ascribed to one common root--the crisis of the agrarian economy. In drawing a map of labor mobility and migration, one should not consider political geography, but the economic motive. Indeed, it was usually the individual laborer who chose where to migrate: whether to stay in the peninsula, to go elsewhere in Europe, or to go across the Atlantic to the Americas. The various destinations, then, represent the most uncertain factor, as where to go depended upon the pushand-pull phenomenon, the individual's choice, and the complex changes in the international labor market. With time, such a complex labor system would reveal a tremendous vitality and would generate more migratory labor. ${ }^{4}$

During the thirty years between 1871 and 1900, Italian agriculture was relatively stagnant in terms of productivity, investment, and mechanization. In order to supplement meager profits, one could resort to seasonal work beyond the Alps or near the Apennines, and to domestic industry. In many villages women and children were employed in domestic industry. The family income thus

\footnotetext{
${ }^{4}$ Enrico Pugliese, L'Italia tra migrazioni internazionali e migrazioni interne. Atti del Congresso Internazionale per il XXI secolo. Dossier di ricerca, Volume II (Rome: Agenzia romana per la preparazione del Giubileo, 2000), 42.
} 
came from a combination of various sources, thus resulting in the formation of a "hybrid society."

The first wave of mass emigration of agricultural laborers was sparked by an agricultural crisis that struck Europe between 1873 and 1896, when prices of main crops produced in the Italian countryside dropped because of an influx of grain coming from the rest of Europe and from the United States. Indeed, since 1873, American grains had invaded European markets, lowering prices. ${ }^{6}$ Rice prices also fell in competition with rice coming from Asia through the Suez Canal. Even silk manufactured in almost every region of Italy entered into competition with Indian silk. Wool production also suffered from miscalculations that sacrificed natural pastures to grain production. This last calamity affected shepherds from Abruzzi, who were the first group of emigrants to leave the motherland. Pasture, sheep, and wool production had provided a livelihood for entire provinces. For example, in Lombardy the province of Bergamo had employed about 30,000 weavers annually for about eight centuries. ${ }^{7}$

Hence a series of calamities--bad crops, low prices, natural disasters, foreign competition, and the crisis of domestic industry--continually strained the peasant population. As a result of all these factors, a huge mass emigration occurred, which may be considered one of the most extraordinary movements in history. As one historian writing just after World War I put it, "In its chief

\footnotetext{
${ }^{5}$ Moch, Moving Europeans, 68.

${ }^{6}$ Ercole Sori, L'emigrazione italiana dall'unità alla seconda guerra mondiale (Bologna: Il Mulino, 1979), 115-117.

${ }^{7}$ Notizie sulle condizioni industriali nella provincia di Bergamo, in Annali di statistica IV (Rome, 1891), 38.
} 
lineaments it has no like. Through the number of men it has involved and the courses it has pursued, through its long continuance on a great scale and its role in other lands, it stands alone." ${ }^{8}$

Though mass emigration movements began earlier, Italian official statistics of emigration began in 1876 when the Italian Bureau of Statistics started an important collection of figures that has been continued ever since. It was Leone Carpi, an economist and journalist who had taken part in the Risorgimento, who diligently compiled a set of figures from 1869 to 1876 . Once the office of the Commissioner General of Emigration was established in 1901, the CGE integrated the available data with the diligent work conducted by Leone Carpi. $^{9}$ The information and statistical data that Carpi had compiled shed light on the social and moral conditions of the new united Italy. ${ }^{10}$

A careful analysis of available data shows some constant features of Italian emigration: emigrants responded both to internal adversities and to external factors pertaining to the labor market. Hence, the migratory curve unfolded in an uneven line, showing peaks and valleys, usually sparked by economic factors such as lack of work. A more constant element was gender:

\footnotetext{
${ }^{8}$ Robert Foerster, The Italian Emigration of Our Times (1919; repr., Cambridge: Harvard University Press, 1924), 3.

${ }^{9}$ Leone Carpi, Dell'emigrazione italiana all'estero (Florence: Civelli, 1871). In this monumental work Carpi reported that about 555,000 Italians lived in what he called Italy's "colonies" abroad. Nearly half of these lived in South America, mainly in Argentina, Uruguay and southern Brazil. Nine percent lived in North America, mostly in the United States. Another third lived in transalpine Europe and 15 percent in North Africa, Greece and the eastern Mediterranean.

${ }^{10}$ Foerster, The Italian Emigration of Our Times, 6.
} 
those who emigrated tended to be men. In fact, it has been shown that the more distant the destination, the higher was the percentage of male emigrants. ${ }^{11}$ During the first phase of emigration (1869-1875), departures averaged about 100,000 per year, peaking in 1872 and in 1873 when 140,680 and 139,860 individuals left. Of these, 70 to 80 percent were men aged twenty to forty, originating from the countryside; women accounted for only 10 percent, as did children under the age of fifteen. As for their origin, male emigrants were mostly from the region of Venetia (Veneto), which at that time contributed 30,000 to 40,000 departures per year. Emigrants came also from other northern regions such as Piedmont, Liguria, and Lombardy, as well as from central and southern Italy (contributing about 5,000 individuals yearly). The reasons for the departures were the continual disintegration and fragmentation of land holdings into smaller and smaller parcels and the crisis of domestic industry. Laborers from Venetia usually went to Austria-Hungary; Piedmontese tended to go to France and, in smaller numbers, to Argentina; Lombards went to France, Switzerland, and Austria; and more and more emigrants from Liguria left for Argentina and Brazil. Beginning in 1864, steam ships left from Genoa for both South and North America. $^{12}$

Mobility across the Alps was due to the agrarian crisis, to the weakening of domestic industry, and also to the building craze that was going on in various parts of Europe such as France, Switzerland, and Austria. Italian peasants and

\footnotetext{
${ }^{11}$ Moch, Moving Europeans, 99.

${ }^{12}$ Notizie statistiche sulla emigrazione italiana all' estero dal 1869 al 1976, in Annuario statistico della emigrazione italiana del 1876 al 1915. Commissioner General of Emigration (Rome, 1926), 1705-1740.
} 
agrarian laborers were willing to leave the field and to migrate temporarily in order to build railroads, bridges, tunnels, and other means of transportation. For instance, between 1872 and 1881, Italian peasants built the St. Gottarde Rail Tunnel, a tunnel through the Alps between Italy and Austria, thus ameliorating communications between the two countries. ${ }^{13}$

As migratory movements intensified both on a European and an intercontinental scale, the new exchange circuits saw not only movements of human beings, goods, and capital, but also an exchange of germs and parasites. For instance, a formidable destructive agent of vineyards, the phylloxera, came from New York to southern France, to move further down to Italy. Moreover, Italian laborers coming back from Austria, France, and southern Germany imported the cholera germ, which provoked two successive deadly epidemics in Italy in 1893 and in 1910-11; however, it was seasonal laborers coming back from Apulia and the Caserta area who contaminated the region of Abruzzo. ${ }^{14}$ Between 1888 and 1897, Italian society faced its most critical years. A series of factors, such as the decline in the price of grains, suspension of trade with France because of a tariff war, and crises in the silk industry and domestic industry prompted a growing number of Italian laborers to emigrate. Adding to this labor outflow was the introduction of labor-saving agricultural machinery and chemical fertilizers which hurt small farmers who could not afford them while favoring the large landowners. For example, in 1888, the province of Mantua,

\footnotetext{
${ }^{13}$ Foerster, The Italian Emigration of Our Times, 165.

${ }^{14}$ Costantino Felice, Il disagio di vivere. Il cibo, la casa, le malattie in Abruzzo e Molise dall'unità al secondo dopoguerra (Milan: Franco Angeli, 1989), 102-103.
} 
already distressed because of continual floods of the Po River, contributed to an unprecedented 6,146 departures out of a total of 25,000 individuals leaving the region of Lombardy that year. ${ }^{15}$

Most interestingly, emigration had now become a family affair. Indeed, the region of Lombardy saw an exceptional number of family departures, as did Piedmont, Emilia, Tuscany, and the Marches. ${ }^{16}$ This remarkable change was a significant indicator of the distress experienced in the countryside of those regions as well as in the rest of Europe where the building craze had also ended. While Europe was in a recession, new labor markets opened in the Americas. Desperate for labor, Argentina and Brazil lured workers by promising free housing, guaranteed employment, land at advantageous prices, and periods of tax exemptions. Hundreds of thousands of Italian adult males started undertaking the journey across the Atlantic. They spent the winter there, earning about 350400 lira, thus doubling their total annual income and avoiding falling into poverty. ${ }^{17}$ Opportunities in Argentina and in Brazil, however, were far from similar. While Argentina offered some promise for social mobility, Brazil became notorious as a place of harsh suffering and broken dreams. ${ }^{18}$

The United States had been a magnet for Italian emigrants since the Italian unification and, by the late nineteenth century, had become the greatest destination of Italian emigrants. The United States represented for them both the

\footnotetext{
${ }^{15}$ Ibid.

${ }^{16}$ Notizie statistiche sull'emigrazione italiana, 189.

${ }^{17}$ Foerster, The Italian Emigration of Our Times, 252-278.

${ }^{18}$ Ibid., 294-298.
} 
promise of a brighter future and the fragility of that dream. By the 1890s, the United States accounted for 20 percent of the entire migratory wave and 36 percent by the second decade of the twentieth century. Between 1906 and 1910, when over 1,300,000 Italians entered the United States, the percentage rose to 41 percent. ${ }^{19}$

Historians have long debated whether emigration from southern Italy was relatively late to occur compared to emigration from the northern regions of the country. The transatlantic migratory wave began in 1879 , when the number of departures from the Italian peninsula reached 24,000 . At that date the southern regions contributed relatively small numbers: Basilicata and Calabria sent 2,500 to Brazil and Argentina and Campania sent approximately 1,000 to the United States. However, by the end of the 1880 s, the numbers had greatly increased. Of the 44,000 Italian emigrants who went to the Americas at that time, 24,000 came from southern regions (10,000 from Lucania and Calabria, 9,000 from Campania, and 5,000 from Abruzzi) went to the United States, while 20,000 northerners (11,000 from Piedmont and 9,000 from Lombardy) went to Argentina. ${ }^{20}$

Although emigration from southern Italy was not late, there were some differences from that of the North. The transatlantic migratory wave from the southern regions shot up between 1885 and 1888, whereas massive northern departures began in 1888 . The abolition of regional customs barriers after

\footnotetext{
${ }^{19}$ Gianfausto Rosoli, ed. Un secolo di emigrazione italiana, 1876-1976 (Rome: Centro Studi Emigrazione, 1978), 27.

${ }^{20}$ Foerster, The Italian Emigration of Our Time, 3-22; Sori, L'emigrazione Italiana, 28-60; it must be noted that during the year 1888, 71,000 emigrants from the region of Venetia went to Brazil lured by the Brazilian government's policy of financing the voyage.
} 
unification in 1861 worsened conditions in the southern regions. The North adapted fairly well to the new legislation because prior to unification, it had already adapted to liberal economic policies, whereas the Bourbons administered the South, operating under strict protectionist rules. After unification, the new rulers extended free trade policies to the South without considering southern conditions. Severe losses were sustained when the new Italian government eliminated marginally productive industries by allowing free competition from the North. Some southern textile producers were accustomed to 100 percent protection, whereas by 1860 in the North Piedmont had reduced its duties to about 10 percent of value. Moreover, the South suffered from poor industrial infrastructure, which tended to limit trade. It was also resistant to the introduction of goods from the North, and its agrarian society was used to local consumption and was much less open to external stimuli. ${ }^{21}$ The abolition of the regional customs barriers, therefore, severely disrupted the southern economy, prompting the earlier migratory phenomenon.

The Italian government brought further ruin to the small landowners in the South by imposing onerous taxes. The burdens on farmers in the form of land ownership, public registry, and succession taxes tormented the Italian countryside. The heavy fiscal burden as well as low wages and high fees could be traced to endemic problems beginning over a hundred years earlier. Along

\footnotetext{
${ }^{21}$ Denis Mack Smith, Italy: A Modern History (Ann Arbor: University of Michigan Press, 1959; reprint 1969), 49-50; Spencer Di Scala, Italy From Revolution to Republic, 1700 to Present (Oxford: Westview Press, 1995), 121-123; Giovanni Carano Donvito, L'economia meridionale prima e dopo il Risorgimento (Florence: Vallecchi, 1928), 58.
} 
with the ill-considered confiscatory fiscal policies of the central government after political unification in 1871 , these were the main causes of southern emigration. ${ }^{22}$ The new taxation was a sort of modern version of ancient relationships of servitude that had long been oppressing the peasantry in the Italian peninsula. It is not accidental that, in the early phase of the great migration, landowners would go after those emigrants who had left behind unpaid debts. Indeed, those laborers had left because it was not worth their while to stay and continue working, simply to be locked in a vicious circle of debts leading to sure eviction. ${ }^{23}$ In spite of harsh conditions, however, southern laborers were the most reluctant ones to undertake the journey across the ocean. Those from Apulia and Sicily, in particular, resisted as long as possible after grain prices began to fall in 1873. ${ }^{24}$ According to historian Gino Luzzatto, at first the fall of grain prices did not prompt agrarian laborers to emigrate and abandon their small parcels of land. In the 1880s, however, the crisis provoked by the phylloxera epidemic, ${ }^{25} \mathrm{a}$ formidable parasite that had affected vineyards in France but spared southern Italian regions for about twenty years, led Italian landowners to plow under grains and plant vineyards in Apulia and Sicily. In these regions, vineyards sprang up and southern producers continued to produce wine, even after the tariff war broke out in the 1880s between Italy and France that limited wine exports to

\footnotetext{
${ }^{22}$ Sori, L'emigrazione italiana, 82.

${ }^{23}$ Gino Luzzatto, L'economia italiana dal 1861 al 1894 (Turin: Einaudi, 1968),183.

${ }^{24}$ Since 1873, American grains had invaded European markets thus lowering prices; see p. 16.

${ }^{25}$ See p.19.
} 
France. It was not until the beginning of the twentieth century that southern laborers abandoned the fields and emigrated to the United States. ${ }^{26}$

The United States then became a sort of Mecca, a promised land for southern Italians. The principal reason for this was the easy availability of jobs in the mining, railroad, and construction industries. The pay was good enough to allow them to pay off old debts and perhaps regain possession of their own foreclosed land. There is plenty of evidence that such factors were good reasons to prompt southern Italian peasants to emigrate, especially small landowners or tenant farmers. ${ }^{27}$

Many of the adult males left with the intention of returning and often went back and forth several times between Italy and the United States. Their goal was to earn enough money to protect their land holdings at home both from foreclosures and from government policies. Hence, for a few decades, migration was seasonal and temporary; there was no total departure, no radical break with the emigrants' roots. ${ }^{28}$

Even permanent migration never excluded completely a possible return to Italy. It is this attitude that explains in part the mushrooming of "Little Italies" where immigrants replicated familiar patterns of social life, preserved their language, and found refuge from the harsh realities they confronted daily outside these "little Italies." Immigrants had to undergo a mysterious process of

\footnotetext{
${ }^{26}$ Luzzatto, L'economia Italiana, 436.

${ }^{27}$ Sori, L'emigrazione italiana, 83-84

${ }^{28}$ Ibid., 86-89.
} 
unmaking and remaking. In the older person, the resistance was greater than in the young. It was the children and the grandchildren, who made concessions more easily because they had less of the Old World to discard, who would become fully integrated into American society. ${ }^{29}$

The exodus from the Italian peninsula continued to increase from the beginning of the twentieth century to the outbreak of World War I in 1914. During that period, the South took the lead while in other regions departures diminished. From Piedmont, there were a total of 30,000 departures, and from Campania 80,000 , while Sicily claimed 120,000 people crossing the Atlantic. Moreover, interregional and transalpine migrations did not stop. Domestic migratory labor continued to be attracted to the Po River Valley, the Roman countryside, and the Sicilian fields. But the number of these domestic migrants diminished. According to figures published by the Italian Labor Bureau, between 1901 and 1905, about one million laborers were involved in interregional migration on the Italian peninsula. ${ }^{30}$

Such tremendous movement of emigrants brought considerable wealth to the Italian peninsula and had an impact on Italian society. The standard of living of those who were involved in the migratory wave improved considerably. According to calculations by Giovanni Lorenzoni, those who came back for brief periods brought with them 500-1,000 lira in gold, while those who returned for

\footnotetext{
${ }^{29}$ Foerster, The Italian Emigration of Our Times, 292-295.

${ }^{30}$ Annuario Statistico Italiano, Vol. III, 265.
} 
good brought 5,000-20,000 lira in gold. ${ }^{31}$ This capital and remittances improved dramatically the standard of living for those who were involved with emigration. As soon as the money sent by the emigrants arrived, the wives who had stayed behind made sure to show off the success of their absentee husbands. They would visit banks, post offices, and notaries; pay off their debts; buy land; and make marriage contracts for their children. Thus the impact of emigration started being felt in society and on those who had stayed. With their husbands away, women started engaging in activities that traditionally had been the exclusive sphere of men. Landlords were now appalled that the poor were no longer poor and that women now seemed to be in command. It looked as if the world had turned upside down. The money sent back home by the Italian emigrants played an important role in the economic policy of the liberal governments and in the behavior of the small industrial, financial, and political circles that implemented it. $^{32}$

Demographic changes, too, were a direct consequence of emigration. The Italian population got older and, of course, with men leaving to find their livelihood elsewhere, society went through feminization. In some areas, entire villages, entire towns, saw their population diminish. The cycle of life experienced tremendous changes. Young people married earlier, and most young men left the country at twenty, often investing their brides' dowries in their journey across the

\footnotetext{
${ }^{31}$ Giovanni Lorenzoni, Inchiesta sulla piccola proprietà coltivatrice formatasi nel primo dopoguerra (Rome: Tipografia Operaia Romana, 1939), 177; please note that before World War I the U.S. dollar equaled 5 lira.

32 Ruggero Romano, “Una tipologia economica,” in Storia d'Italia (Turin: Einaudi, 1972), Vol. I, 260.
} 
ocean. In spite of the distance, a wife could share successes and failures, pains and struggles, and could be entrusted with savings more than could fathers or brothers. There were also those who left their towns and vanished in the big metropolis overseas, formed a new family nucleus, and never again returned to the point of origin. ${ }^{33}$

The family, whether it was a complex network of elaborate kinship or a small nuclear unit, did change. Those who were emigrating, while waiting on the pier to board the ship, often entrusted their wives and children to their own parents, even though usually not to live under the same roof. Rarely did young men who had emigrated return to the paternal home after having emigrated. Having experienced independence and autonomy, they found it hard to return to the parents' home. ${ }^{34}$

The family as an institution, however, somehow survived the trials and tribulations connected with the harsh conditions of emigration and separation. Since young couples were separated for long periods of time, the number of births diminished. The remittances, however, were the main support of the family itself. $^{35}$

Besides influencing society, the continuous influx of foreign currency had an impact on the Italian economy; it helped finance industrialization in Italy in the

\footnotetext{
${ }^{33}$ Gino Arias, La questione meridionale (Bologna: Zanichelli, 1921).

${ }^{34}$ PierPaolo Viazzo and Dionigi Albera, La famiglia contadina nell' Italia settentrionale 1750-1930, in Marzio Barbagli and David Kertzner, eds, Storia della famiglia italiana, 1750-1950 (Bologna: Il Mulino, 1992), 170.

${ }^{35}$ Giorgio Mortara, Le popolazioni delle grandi città italiane (Turin: Unione Tipografica Editrice Torinese, 1908).
} 
early twentieth century. Since the country had a scarcity of raw materials and had to import them from abroad, the steady influx of dollars, francs, and German marks brought in by Italian workers helped fuel the country's industrial and commercial expansion. From this perspective, then, there was a difference between internal migration and emigration. The macroeconomic effect on the Italian economy was remarkable. Moreover, the Italians abroad always demanded products from their home country, thus stimulating exports. ${ }^{36}$ As the migratory phenomenon came to maturity and the influx of foreign currency became more regular, the domestic market also benefited. The money sent by emigrants purchased property, paid debts, or made investments that would immediately yield profits. It was also deposited in post offices and invested in government bonds. Such availability of money allowed the state to divert the emigrants' savings to the financing and development of the northern "industrial triangle." 37

In an analysis of the effect of emigration's earnings on microeconomics as well as macroeconomics, Antonio Gramsci observed that the Italian government offered state bonds at a good interest rate to emigrants and their families, thus making emigrants unwitting subsidizers of the industries of the North. ${ }^{38}$ The emigrants' money thus had positive effects on the Italian economy--except for some extreme cases of waste and abuse, such as the war in Libya in 1911-1912

\footnotetext{
${ }^{36}$ Gino Arias, La questione meridionale (Bologna: Zanichelli, 1921), 420.

${ }^{37}$ Ibid.

${ }^{38}$ Antonio Gramsci, La questione meridionale (Rome: Editori Riuniti, 1970), 56; Sori, L'emigrazione italiana, 122-123.
} 
or the collapse of the Banca di Sconto on December 29, 1921, which swallowed most of the emigrants' savings. The Italian economy continued to operate by allowing the subordination of the South, or Mezzogiorno, to the development of industry and capitalism in the most advanced areas to the North. This trend was consistently visible, even though it would be implemented through a sort of underground financial channel, through the emigrants' money. ${ }^{39}$

Indeed, a favorable exchange rate, resting upon emigrants' remittances, stimulated Italian imports from foreign countries. Imports exceeded exports for a value of 10,230 million lira in the ten years between 1902 and 1912, especially because of the necessity of supplying raw materials for the infant Italian domestic industry, a trend supported by the high tariffs of 1878 and 1887; about $61 \%$ of such imports were purchased with moneys from immigrants' deposits. ${ }^{40}$ Emigration remittances together with earnings in the tourism and merchant marine sectors contributed to an improvement in the balance of international payments. Moreover, government bonds that had been purchased abroad had positive effects on the exchange rate with foreign currencies. In this way, the emigrants' remittances became a way to transfer resources from agriculture to industry, thus rendering the major Italian commodity--the labor force--the most competitive one in the international market. ${ }^{41}$ Hence, the emigrants' remittances became an essential factor in the particular model of national industrial

\footnotetext{
${ }^{39}$ Sori, L'emigrazione italiana,123; Ciuffoletti and Degli Innocenti, L'emigrazione nella storia d'Italia, 128-129.

${ }^{40}$ Franco Bonelli, Il capitalismo italiano. Linee generali d'interpretazione, in Storia d'Italia, Annali I, Dal feudalesimo al capitalismo (Turin: Einaudi, 1978), 1193-1255.

${ }^{41}$ Ibid.
} 
development taking place in Italy, based as it was on the important action of the state's functioning as financial intermediary in order to compensate for the lack of self-financing capabilities of domestic industry. ${ }^{42}$

The exodus of Italian laborers continued in increasing numbers until World War I. When the Great War broke out, the Italian immigrants who lived in the United States had to choose between returning to Italy and being sent to the front to fight or enlisting in the United States Army. In spite of the late involvement of the United States in the war, the atmosphere in America was one of hostility to aliens and foreign-born immigrants. Moreover, the large German community engendered exaggerated fears of spies, hysteria, and hatred of all things German, and hostility to dissenters. In addition, the Russian Revolution and the triumph of Bolshevism frightened many Americans, culminating in a Red Scare and subsequent witch-hunting hysteria in 1919. Although the worst excesses of the Red Scare abated rapidly, it continued to influence American society throughout the 1920s. The foreign-born lived with an uneasy realization that they were viewed with hostility and suspicion. A wave of xenophobia swept across the country during the 1920 s. $^{43}$

The nativism that came to the fore in 1920-1924 had its basic roots in the pre-war years. It consisted of hatred toward Catholics, Jews, and southeastern Europeans. The war had suspended that kind of animosity, shifting the focus to patriotism. However, after the war ended and the immediate post-war period

\footnotetext{
${ }^{42}$ Ibid.

${ }^{43}$ Robert A. Divine, et al., America Past and Present, 3rd ed. (New York: Harper Collins, 1991), 752-753.
} 
passed, the Red Scare and Bolshevik fears became catalysts in increasing American intolerance of immigrants. The Anglo-Saxon and anti-Catholic tradition of the pre-war era remained the distinctive character of the nativism of the 1920 s. Racial nativism continued to focus on the "new immigration" from southern and eastern Europe, together with the Japanese; it was rooted primarily in racial feelings and rationalized by the scientific determinism and the eugenics of the Progressive era. ${ }^{44}$ Anti-immigrant feelings culminated in the approval by the U.S. Congress of legislation in 1921 and 1924, providing for a quota system concerning coexistence in the United States of each ethnic group. The 1921 law based the quota on the 1910 census, while the more restrictive 1924 law based quota on the 1890 census. ${ }^{45}$

The Law of 1921 was a very significant law for the development of American immigration policy. It imposed the first significant numerical limits on European immigration. It established a nationality quota system based on the pre-existing composition of the American population--an idea that has persisted in all subsequent laws. The law would not affect existing arrangements that excluded most Asiatic immigration, nor would it interfere with unrestricted immigration from Canada and Latin America. It would limit, however, European immigration during the coming year to three percent of each nationality present in the United States at the time of the last available census, that of 1910. This percentage plan would limit the new immigration to an annual maximum of a

\footnotetext{
${ }^{44}$ John Higham, Strangers in the Land: Patterns of American Nativism, 1860-1925 (1955; repr., New Brunswick: Rutgers University Press, 1998), 265-267.

${ }^{45}$ Ibid., 310-311.
} 
quarter of a million people without reducing the flow from northwestern Europe. It ensured especially that the so-called "new immigration" could not reach more than a small fraction of its pre-war level. In the long run, the law of 1921 proved to be the most important turning point in American immigration policy. In the words of John Higham, "the immigration policy now adopted meant that in a generation the foreign-born would cease to be a major factor in American history." 46

The National Origin Act of 1924 limited quotas to 2 percent of the number of foreign-born residents of each nationality based on the census of 1890 . Exemption from these quotas was permitted only for the wives and minor children of American citizens, not for the wives and the children of aliens. The law prohibited Japanese immigration, thus setting the stage for a diplomatic crisis with Japan. As for Europeans, the law established a certain number of inspections overseas and required the immigrant to obtain a special "immigration visa" from an American consul abroad. Hence quotas were to be filled by counting the number of visas issued rather than by counting the immigrants after their actual arrival at an American port. According to John Higham, "together with the provisions of the law of 1917 which still remained in effect, the new statute erected a formidable wall." 47

As the Great War and its aftermath changed America, so they also dramatically changed Italy. During the conflict, emigration came to a virtual halt,

\footnotetext{
${ }^{46}$ Ibid.

${ }^{47}$ Ibid., 324.
} 
except for small groups of women and children who were permitted to join relatives abroad. The end of hostilities and of the economic disruption that the war had caused produced a massive new wave that, in 1920, saw 357,000 Italian immigrants amassed at the port of New York. By 1921, another 100,000 had arrived at Ellis Island; the 1921 law reduced the number from May 1921 to July 1922 to $42,000 .^{48}$

The closing of the American gates forced Italian emigrants to find their livelihood in South America and other regions, but almost everywhere, labor markets were being closed to immigrants. The end of the liberal era marked by the pre-World War I international system of free trade and exchange of goods and labor was followed in Italy by the rise after the war of the fascist movement whose policies on these matters departed dramatically from those of the liberal era.

The establishment of the fascist state in 1922 by Benito Mussolini formally ended the debate and placed the Italian government squarely against emigration. It did not, however, resolve the issue of what were Rome's responsibilities toward its nationals abroad and what it should reasonably expect or demand from them. These issues often strained relations between the Italian government and its nationals abroad. More seriously, they proved to be severe points of contention between Rome and several foreign governments.

Traditionally, Italian political and government officials had expressed contrasting opinions concerning emigration. Some decried the draining of

\footnotetext{
${ }^{48}$ Pellegrino Nazzaro, "Italy from the American Immigration Quota Act of 1921 to Mussolini’s Policy of Grossraum 1921-1924,” The Journal of European Economic History 3 (1974).
} 
manpower from the country; others emphasized the opportunity for landless laborers to become landowners by emigrating abroad, saving their earnings, and then being able to buy land upon return. Indeed, the prospect of owning land was a highly motivating factor for those who decided to leave the homeland.

However, whether optimistic toward emigration or opposed to it, the Italian ruling class had not been able to forge a coherent and vigorous emigration policy that would provide protection and assistance to the emigrants. ${ }^{49}$ As a result, over a long period and throughout the tenure of many governments practical considerations prevailed and limited Italy in its dealings with the U. S. government over the protection of Italian emigrants in America.

${ }^{49}$ Ferdinando Manzotti, La polemica sull'emigrazione nell'Italia unita fino alla prima guerra mondiale (1962; repr., Milan: Società Editrice Dante Alighieri, 1969), 183. 
CHAPTER III

\section{EMIGRATION LAWS AND POLICY FROM THE LIBERAL STATE TO THE}

FASCIST STATE

The political debate concerning emigration and the subsequent laws and policies implemented reflected every different political and economic ideology present in Italy from the completion of the country's unification through the following decades. However, whatever their political views, politicians approached the migratory phenomenon looking mostly at its consequences and effects on the mother country rather than trying to understand the roots of the problem and its immediate causes. Moreover, as the migratory wave continued to increase to record numbers, the domestic political debate was influenced by the international context in which it occurred, first in Europe and then in the Americas. In addition, as the United States became the Italian immigrants' favorite destination, Italian politicians and policymakers had to deal with diplomatic crises and the problem of protection of Italian nationals in the United States according to their treaty rights. Despite the passion and indignation which Italian politicians expressed when Italian nationals were victimized overseas, pragmatism prevailed as the dominant theme in Italy's approach.

From the very beginning of the debate in the 1860s, Italian politicians tended to express negative feelings concerning emigration. The very first to address the issue of emigration in the Italian Parliament was the deputy Ercole Lualdi, at the end of January 1868. Lualdi emphasized the possible dramatic consequences, together with humane and patriotic concerns, of the migratory 
phenomenon. A notorious protectionist, Lualdi opposed emigration on both humane and national security grounds. He blamed the government's policies of heavy taxes on industrialists and low tariffs on imports for the failure of domestic producers to create jobs for Italian workers. One of the remedies he proposed was for the government to invest capital in job-creating remedies. ${ }^{1}$ Responding to Lualdi, Prime Minister Luigi Federico Menabrea (P.M. October 1867November 1869) argued that it was the responsibility of industrialists and entrepreneurs in every sector to make sure that each Italian citizen could find work at home. ${ }^{2}$ It is interesting to note that only a few days earlier, the Minister of the Interior, Luigi Cadorna, had issued a circular letter ordering prefects, mayors, and police to forbid departures for Algeria or the Americas of emigrants who did not have a job waiting for them at their new destination or who did not have enough cash to survive while looking for a job. Sidney Sonnino, a politician who investigated the depopulation of the South, in criticizing this absurd order, observed that the emigrant was required to have capital, the lack of which was the primary cause of his decision to leave the homeland. ${ }^{3}$ The clear intent of the Cadorna circular, however, was to give Parliament the power to control emigration without issuing a specific law.

\footnotetext{
${ }^{1}$ Ercole Lualdi's speech is printed in its entirety in Zeffiro Ciuffoletti and Maurizio Degli Innocenti, L'emigrazione nella storia d'Italia 1869-1975. Storia e documenti (Florence: Vallecchi, 1978), 7-13.

${ }^{2}$ Ibid.

${ }^{3}$ Eugenio Sonnino, "Problemi di metodo e primi risultati di una ricerca sullo sposopolamento dei comuni italiani dopo l’Unitá,” in Ercole Sori, ed., Demografia Storica (Bologna: Il Mulino, 1975); Fernando Manzotti, La polemica sull'emigrazione nell'Italia unita fino alla prima guerra mondiale (Milan: Società Editrice Dante Alighieri, 1962; reprint 1969), 35; Gianfausto Rosoli, ed., Un secolo di emigrazione italiana, 1876-1976 (Rome: Centro Studi Emigrazione, 1978), 254-255.
} 
A few years later, in January 1873 , another circular issued by Giovanni Lanza (Prime Minister and Minister of the Interior, December 1869-July 1873), issued the same orders to prefects and police and added a provision requiring emigrants to provide a guarantor who would be responsible for paying the fees for a return voyage in case the individual had to be repatriated via consular ordinance. Moreover, emigrants were counseled not to emigrate in order to avoid falling easy prey to speculators and labor exploitation. ${ }^{4}$ To those who opposed emigration, Lanza proposed approaching it with optimism and reflecting on the advantages that emigration had brought to other countries such as Germany. Moreover, as Lualdi had done a few years earlier, Lanza too emphasized the need for greater efforts by landowners to ensure more work opportunities and better conditions for Italian agrarian laborers so that they would not be forced to leave the homeland. ${ }^{5}$ As historian Fernando Manzotti points out, there was an apparent contradiction in burdening landowners with more and more taxes while expecting them to improve the conditions of agrarian laborers and to modernize and industrialize agriculture. ${ }^{6}$

Even members of the party in power during those years, the "Right" (the heirs of Count Camillo Cavour, Piedmontese Prime Minister and architect of the unification of Italy), deemed such regulation to be oppressive. Moreover, they claimed that, besides violating personal liberties, it damaged the development of

\footnotetext{
${ }^{4}$ The Lanza's circular is reprinted in Ciuffoletti and Degli Innocenti, L'emigrazione e la storia d'Italia, 31-35.

${ }^{5}$ Ibid.

${ }^{6}$ Manzotti, La polemica sull'emigrazione, 13.
} 
the merchant marine, thus increasing the exodus of Italians from the mother country. Hence, the circulars of both 1868 and 1873, which had been issued while the Right was in power, had a tendency to coerce rather than protect, regulate rather than safeguard. Most of all, they had been framed based on fear of the consequences of emigration on Italian society rather than on an effort to understand the causes, origins, and sources of emigration itself. ${ }^{7}$

By 1876, the "Left" (Mazzinians who had abandoned their republican ideals and shifted to the Piedmontese camp to make unification possible) was in power. Their leader was Agostino Depretis, a very able politician known as the initiator of the practice of "Transformism" in the Italian Parliament. When a member of the opposition had become too influential to be ignored, he would be "transformed or included in the cabinet. ${ }^{8}$ Arguing that the regulatory norms initiated by the Right were repressive and coercive, the Left sought to tone them down through another circular issued on April 28, 1876, named after Minister Baron Giovanni Nicotera. It declared that emigration would be tolerated but that emigrants would have to bear full responsibility for their own safety once they left the homeland. The Nicotera circular acknowledged that the Lanza circular had not achieved its purpose, i.e. to regulate emigration. In fact, in order to avoid regulatory restrictions, emigrants who did not have legal passports tended to

\footnotetext{
${ }^{7}$ Ciuffoletti and Degli Innocenti, L'emigrazione e la storia d'Italia, 31-35.

${ }^{8}$ It must be noted that, by the early 1880s, the Right and the Left had become indistinguishable, and quite often members of the Right voted in favor of Leftist government proposals while members of the Left voted against them. Depretis noticed that and argued that the Right had been "transformed." Therefore, its leaders would be welcomed in his cabinets. Ever since, when leaders of the Right or the Left formed cabinets, members of both groups would be included. Unfortunately, with time, the term "transformism" acquired a derogatory connotation as synonymous with corruption while in office.
} 
leave from foreign ports where no legal documentation was required. One major consequence was the loss of business by the Italian merchant marine, which was deprived of the opportunity to transport Italian emigrants across the Atlantic. ${ }^{9}$

The Nicotera circular aimed at suppressing abuses by the agents who were deemed to be responsible for all the evils endured by the emigrants. It was one of the most noteworthy emigration acts passed by the Left. ${ }^{10}$ However, a few months later Nicotera issued another circular that urged prefects to grant passports only to emigrants with sufficient funds to face a transatlantic journey. He also urged them to do whatever possible to discourage so called "artificial" emigration, the exodus encouraged by unscrupulous agents. This second circular clearly contradicted the first one, for restriction concerning passports was a clear violation of the freedom to expatriate, and the restrictions encouraged clandestine emigration. ${ }^{11}$

Until 1888, Parliament continued to debate emigration laws without much success. Defenders of emigration continued to argue that it helped maintain social order by easing the pressure of overpopulation and rural poverty and by creating foreign markets for national goods. Opponents of emigration raised fears of higher wages as a result of the loss of manpower and of the weakening of the institution of the family with wives abandoned and children growing up without

\footnotetext{
${ }^{9}$ Manzotti, La polemica sull'emigrazione, 40.

${ }^{10}$ Sonnino, "Problemi di metodo e primi risultati," 267.

${ }^{11}$ Manzotti, La polemica sull'emigrazione, 41.
} 
fathers. ${ }^{12}$ One important consideration absent from the debate was that, for a great number of Italians, the exodus meant finding una ragione di vita, a way of life, a means of survival, and that laws were unlikely to deter them from pursuing that dream. ${ }^{13}$

During the 1880s, official opposition to emigration diminished as the debate shifted from whether it should be permitted to how it should be managed. Should it be spontaneous, or should it be regulated and controlled by the government? Should Italians be permitted to establish free communities in the Americas where most of them were choosing to settle, or should the government promote settlement in Africa where Italy aspired to build a colonial empire? The shift in focus stemmed from the changes that Italy was going through at the time. In the 1870 s, Italy was a poor agricultural country, a young nation recently formed and still struggling with its own post-unification problems such as forging a national identity, building social infrastructures, and strengthening the economy. By the 1880s, Italy had launched a program of industrialization and modernization at home, at the same time engaging in colonial adventures in Africa and attempting to play a bigger role in European affairs. ${ }^{14}$ Directing emigrants to African colonies where they could become partners with the state in promoting Italian economic, cultural, and international interests became the logical alternative to spontaneous emigration. In Africa, proponents argued,

\footnotetext{
${ }^{12}$ A detailed analysis of debates in the Italian Parliament in the 1870s can be found in Manzotti, $\mathrm{La}$ polemica sull'emigrazione, 29-48.

${ }^{13}$ Sonnino, "Problemi di metodo e risultati," 267.

${ }^{14}$ Denis Mack Smith, Italy: A Modern History (1959; repr., Ann Arbor: Michigan, 1969), 148-157.
} 
Italian farmers could find "a place in the sun." As Deputy Francesco De Renzis put it, "the Mediterranean would be the cure for the social and economic problems of Italy and the Italians." 15

One of the features of Italian colonialism in Africa was that it was based largely on aspirations for prestige rather than on a solid economic foundation. Consequently, divisions ensued between those advocating the peaceful establishment of communities in the Americas and those who advocated imperial conquest in Africa. The debate was intense within the Societa' geografica italiana, one of the major agencies formed to promote colonial expansion. Founded by Cristoforo Negri in 1869, the society's members were divided on this issue. A supporter of Italian settlement particularly in Argentina, Negri became the greatest advocate of a "greater Italy" in the Americas rather than in Africa. However, he too may be considered a symbol of the dilemma that divided politicians, economists, and policymakers in Italy. In fact, with time his vision of a greater Italy changed and, by 1870 , he favored a greater Italy in Africa rather than in America. He argued that it would be easier for emigrants to maintain their cultural identity by staying closer to Italy and that emigration to America should be discouraged and redirected to Africa. ${ }^{16}$

The debate resulted in passage of the first important law regulating emigration on December 30, 1888, n. 5866. The law was sponsored by Prime

\footnotetext{
${ }^{15}$ Ciuffoletti and Degli Innocenti, L'emigrazione nella storia d'Italia, 126-128; Grazia Dore, La democrazia italiana e l'emigrazione in America (Brescia: Morcelliana, 1964), 162.

${ }^{16}$ Ciuffoletti and Degli Innocenti, L'emigrazione nella storia d'Italia, 148-149; an excellent discussion of the concept of a "greater Italy" is contained in Dore, La democrazia italiana.
} 
Minister Francesco Crispi (P.M. August 1887-February 1891), who succeeded Agostino Depretis. A Sicilian politician, a former republican follower of Giuseppe Garibaldi, Crispi had abandoned his republicanism and had embraced monarchism as the best way to ensure national stability. At first he was an opponent of emigration, but he had come to accept it as an inevitable phenomenon, provided that it was state-directed. A committed nationalist, Crispi recognized some of the positive aspects of emigration, including a means of economic expansion for the country. He too, however, was not able to decide on the key issue: was emigration good or bad? Should it be encouraged or should it be limited? Moreover, he too continued to operate along the lines of coercion and repression rather than protection of the emigrant from exploitation. Even when measures were aimed at limiting agents' abuses and curtailing the so called "artificial emigration," it seemed that the law was meant to ease the pressure put on the government by the landowners rather than to pay attention to the interests of the peasants and emigrants. Basically, since the very day he introduced his law proposal, Crispi harbored some uncertainty concerning emigration, and these would be reflected in the law he sponsored. ${ }^{17}$

The 1888 law had all the characteristics of legislation intended to ensure public order. It recognized the freedom of the individual to emigrate; it regulated the activities of agents and subagents, who had to obtain a license from the Ministry of the Interior in order to conduct their activities; it regulated the terms of the transport contract; it protected the emigrant from being forced to pay the price

\footnotetext{
${ }^{17}$ Manzotti, La polemica sull'emigrazione, 82-83.
} 
for passage with indentured labor once abroad; and it created a special arbitration commission in order to resolve controversies between emigrants and transportation agencies. ${ }^{18}$ Ultimately, the law aimed at giving Italian authorities the ability to control emigration in order to suppress illegal activities. Hence, although still restrictive, the law forced shipping companies to obtain necessary licenses, and it protected emigrants from agents and recruiters who often cheated them with labor contracts that reduced them to virtual servitude. Such was the simple purpose of the law. However, how should the state protect without direct control? It was still unclear whether the promoter of the law deemed emigration good or evil. In spite of its internal contradiction, however, the law represented the first important acknowledgement of the necessity for the government to intervene. ${ }^{19}$

Indeed, the important issue was the transport contract, which now had to be in writing and had to offer the ignorant masses protection from the perils that they might encounter on the journey to new destinations. The law, however, did not address what could happen to the emigrant after landing in his new destination. As Francesco Saverio Nitti pointed out, the emigrant who was taken by the hand and accompanied to the ship could still be thrown overboard and

\footnotetext{
${ }^{18}$ Atti Parlamentari Camera Deputati, Documenti, XVI Legislature, 1887, n. 85. Crispi’s law gave way to a heated debate. For example, Carlo Rosmini, "Il nuovo progetto sull'emigrazione," in Il Giornale degli economisti, III (1888): 121-174 was in favor of freedom of recruitment and demanding more caution by the agents. Other newspapers, such as $L$ 'Economista, did not agree with the need for a special law arguing that the penal law code should be sufficient. See also Rosoli, Un secolo di emigrazione italiana, 253-255.

${ }^{19}$ Manzotti, La polemica sull'emigrazione, 95.
} 
completely abandoned at sea. ${ }^{20}$ An example of how little the law considered the physical safety of the emigrant can be seen in the provision that only a minimum of only one cubic meter per passenger must be allocated aboard the ship. The law also included a number of restrictions such as prohibiting married women from emigrating without the husband's consent. This limitation was based on the premise that emigration was an extraordinary event, outside of the ordinary administrative routine about which women could make their own decisions. It would not be until the law of July 17, 1919, n. 1176, that such a restriction would be eliminated. ${ }^{21}$

Men, too, had restrictions. For example, they were all but forbidden to depart before the age of thirty-two if they had not met their military obligations, and those who did were considered virtual exiles. In the case of recall back home in the event of war, no provision existed to facilitate the process. Children of emigrants were also required to provide military service, unless they renounced Italian citizenship. ${ }^{22}$

Thus, even though the 1888 law had established that emigration would be free, its overall aim was restrictive. "It was a law, like so many others, prompted more by fear than by a subtle understanding of its theme."23 The parliamentary

\footnotetext{
${ }^{20}$ Francesco Saverio Nitti participated in the debate with a pamphlet in 1888 that revealed his position in the liberal mainstream by looking at emigration as a product of poverty as well as of progress and industrialization. He then criticized Crispi as being still linked to the concept of emigration as a necessary evil. See also Francesco Saverio Nitti, Scritti sulla questione meridionale, vol. I (Bari: Laterza, 1958), 353364.

${ }^{21}$ Manzotti, La polemica sull'emigrazione, 82-89.

${ }^{22}$ Ibid.

${ }^{23}$ Foerster, Italian Emigration of Our Times, 475.
} 
debate over the law was focused more on southern agrarian interests and on the interests of the navigation companies than on the emigrants' needs. In the South, members of the middle class who had played a key role as agents in this lucrative labor trade continued to make their handsome profits. The southern middle class did not want the state to organize and regulate emigration, for such actions deprive those who were involved in recruiting, shipping, and choosing destinations of very lucrative profits. ${ }^{24}$

It was religious institutions (such as the Congregation of the San Carlo missionaries, founded by Giovanni Scalabrini in 1888 , and the Humanitarian Society), that, more than the government, attempted to shield emigrants from ruthless exploitation. Their voices were heard during the debate preceding passage of the law of $1901 .^{25}$

The law of 1901 was ground-breaking. It was introduced as a proposal in the Chamber of Deputies by Luigi Luzzatti and Edoardo Pantano in November 1900. It became law on January 31,1901 (n. 23). ${ }^{26} \quad$ The most important feature of the legislation was the creation of the office of Commissioner General of Emigration (CGE), reporting to the Ministry of Foreign Affairs. This important new agency was meant to protect the emigrant as well as to connect the private individual with public institutions. ${ }^{27}$

\footnotetext{
${ }^{24}$ Dore, La democrazia italiana, 64-65.

${ }^{25}$ Manzotti, La polemica sull'emigrazione, 89.

${ }^{26}$ Atti Parlamentari Camera Deputati, Legislature XXI, session 1900, Documenti, no.44.

${ }^{27}$ Foerster, Italian Emigration of Our Times, 478-479.
} 
According to the law, no one could recruit emigrants or promise or sell tickets without a license issued by competent authorities to the navigation companies. Each shipping company could appoint representatives in the various provinces of Italy, although in the Italian countryside the same old agents continued to recruit emigrants as well as to organize and manage their futures. Hence, the migratory phenomenon remained an autonomous event, as intermediaries in the South had always wanted it, the only difference being that the state now had appointed a Commissioner General of Emigration to safeguard the emigrant. The role of the CGE was to regulate all activities before boarding and during the journey, but he did not have the authority to intervene at the most delicate and difficult time--the time of landing in new lands, when the emigrant was left in the hands of local authorities. ${ }^{28}$

These rules represented, however, considerable improvement over the previous regulations. Not only did navigation companies have to obtain a license to transport emigrants, but they had to do so at fixed rates and had to pay a tax of eight lira for every ticket sold. Proceeds from the tax, as well as all license fees, were paid to an Emigration Fund administered by a Parliamentary Committee, with the money used exclusively for the benefit of the emigrant. Moreover, through the publication Bollettino dell'Emigrazione, the CGE offered emigrants a wealth of information on all matters of vital importance to them. The

\footnotetext{
${ }^{28}$ Dore, La democrazia italiana, 93-94.
} 
Bollettino remains a major source of information for the scholar of Italian emigration history. ${ }^{29}$

The Commissioner General also established numerous local subcommittees, thousands of them, spread all over Italy in order to keep those who aspired to emigrate informed. These committees, however, did not always function efficiently because of conflicts with local officials such as mayors, doctors, and priests, who feared a loss of prestige and power to the committees, and because of mistrust on the part of emigrants, who suspected that the committees might try to keep them at home..$^{30}$

Although the office of the CGE was not always efficient in coordinating the activities of the numerous local subcommittees, it was considered generally successful in advocacy for the emigrant. The law assigned numerous tasks to the Commissioner General: approval of representatives' appointments, supervision of their activities, assistance to the emigrants before boarding and during the journey, protection of women and children, suppression of clandestine emigration, and dissemination of useful information for the emigrant. Two auxiliary bodies were also created to assist the office of the CGE in carrying out its responsibilities: the Emigration Council, a broadly representative body of twelve persons who met at least twice a year to discuss the most pressing issues that called for action by the CGE, and the Parliamentary Vigilance Committee, tasked with guaranteeing the management of the Emigration Fund. To this

\footnotetext{
${ }^{29}$ Foerster, Italian Emigration of Our Times, 479; Dore, La democrazia Italiana, 95.

${ }^{30}$ Foerster, Italian Emigration of Our Times, 480.
} 
Emigration Fund were credited all license fees and the tax of eight lira that the law of 1901 required every carrier to pay for every ticket sold. According to the law, no expenditure was allowed except for the exclusive advantage of the emigrant. ${ }^{31}$ The management of available funds, however, gave rise to numerous attacks and severe criticism of the CGE activities from those who wished to return some of its functions to the Ministry of the Interior, the Foreign Ministry, and the Navy.

Agrarian interests and liberal politicians also opposed the CGE. The former were always worried about the exodus of laborers and the consequent rise in wages. The latter, who favored abolishing state taxes, ended up favoring the interests of the navigation companies. Actually, a mere look at the growing number of emigrants from Italy soon after the implementation of the 1901 law indicates that the system of protection of the emigrants may very well have been indicative of the merits of the law itself. It can be said that the positive effects of the law were indeed one main cause of the increasing numbers of emigrants. ${ }^{32}$

Criticism of the law, however, persisted and focused on the management of the Emigration Fund. Attacks concerning financial issues were often political in nature and were aimed at weakening the office of the CGE. For example, in 1907, Francesco Montagna, spokesperson for the Finance Committee of Emigration, disagreed with other committee members while presenting a report concerning the budget. He took the opportunity to put forward a critical analysis

\footnotetext{
${ }^{31}$ Ibid., 479.

${ }^{32}$ Carlo Ferraris, “Il movimento generale dell'emigrazione italiana: suoi caratteri ed effetti," in Bollettino dell'emigrazione, no. 5 (Rome, 1909).
} 
of the Commissioner General, recommending that the law be modified, that the Office of the CGE be dismantled, and instead that Italian consulates abroad be strengthened to protect the emigrant. ${ }^{33}$

There were also defenders of the 1901 regulations such as Luzzatti, the father of the law, who continued to stress in Parliament that before the law's passage in 1901, emigrants were the victims of police repression, an anarchical legal system, and neglect by their own government. ${ }^{34}$

Indeed, the law strengthened protection of the emigrant before departure and during the journey, and its protection remained the object of liberal governments for two decades in spite of continued attacks and criticism. ${ }^{35}$ One reason for the enduring support was acceptance of the premise that emigration was a crucial contributor to internal social peace by serving as a "safety valve" for internal social tension. Another reason was the visible contribution that emigrants' remittances made to national revenues and to the capitalist development of the country. Yet, in the years between 1906 and 1908, while many politicians acknowledged the advantages of emigration, the old debate over the benefits of emigration to the nation was revived. ${ }^{36}$

One important example of such polemic is the confrontation in the Italian Senate between Pasquale Villari and Giustino Fortunato. The former tended to

\footnotetext{
${ }^{33}$ Francesco Montagna, Relazione della Giunta Generale del bilancio sugli stati di previsione del Fondo per l'emigrazione per l'esercizio 1907-1908, in Bollettino dell'emigrazione, no. 5 (Rome, 1908); Manzotti, La polemica sull'emigrazione, 147.

${ }^{34}$ Manzotti, La polemica sull'emigrazione, 149.

${ }^{35}$ Ibid.

${ }^{36}$ Ibid., 150.
} 
see the migratory phenomenon as a terrible illness, a serious "virus" that could only worsen the condition of Italian society. He claimed that Italian emigrants were cruelly exploited in America, where human exploitation was the only means to climb up the social ladder. While working in America, Italian nationals became accustomed to this system of human exploitation. Once they returned to the mother country, they themselves tended to exploit their fellow citizens. Hence, working abroad changed these Italian citizens, making them worse than they were prior to their departure; one could not call it progress that, upon their return, they began to exploit their fellow citizens. Rather than emphasizing the benefit represented by the remittances in dollars, Villari pointed to the degeneration of Italian society caused by the "virus" returning emigrants brought with them with the dollars. Villari criticized policymakers for focusing merely on the economic benefits of emigration rather than its more harmful social effects on Italian society. ${ }^{37}$

Giustino Fortunato rejected Villari's argument. He conceded that emigration brought changes to Italian society, but he pointed out that demographic pressure rendered emigration inevitable. He argued that the realities of the new Italy required the shaping of a new Italian national identity, one more representative of the new social and economic forces and called on the Italian government to take the lead in this undertaking. ${ }^{38}$

\footnotetext{
${ }^{37}$ Ibid.

${ }^{38}$ Ibid.; see also Pasquale Villari, Scritti sull'emigrazione e sopra altri argomenti vari (Bologna: Zanichelli, 1909).
} 
Most interestingly, the debate also revived the polemic over whether the migratory flux should be allowed to flow where it would or whether the state should intervene by directing it to colonies. Numerous parliamentary debates as well as a vast literature on the subject reveal the intensity of the discourse. In the Italian parliament, deputies favoring state-directed emigration proposed to acquire colonies in order to secure "a place under the sun" for Italian farmers. Proponents of Italian colonies in Africa argued passionately. The most effective voice was that of Enrico Corradini, novelist, writer, and founder of modern Italian nationalism. In an article that he published after a trip to South America, he wrote that there was no protection of Italian emigrants in receiving countries, and that Italian nationals were simply abandoned to their destiny. ${ }^{39}$ Protection of the emigrant, although well meaning, always ended as soon as the emigrant had reached a foreign land. The Commissioner General of Emigration, Corradini maintained, did not protect the emigrant as articles published on the Idea Nazionale claimed. Such claim was only a smoke screen to hide the government's indifference concerning the migratory flux. ${ }^{40}$ Rather than lose its laborers and contribute to the wealth and power of other nations, Italy must become less of an emigrant nation and more of a colonizing nation. ${ }^{41}$

Social reformers opposed establishing colonies in Africa, claiming that Italy must take care of its problems at home rather than depleting its limited

\footnotetext{
${ }^{39}$ Enrico Corradini, Discorsi politici 1902-1923 (Florence: Vallecchi, 1923), 79.

${ }^{40}$ Ibid.; The article "L'emigrazione nel paese e nel Parlamento" was published in L'Idea Nazionale on 15 March 1911.

${ }^{41}$ A discussion of Corradini's view can be found in Manzotti, La polemica sull'emigrazione, 205-207.
} 
resources in costly colonial expansion. In particular, members of the growing Socialist movement favored emigration to countries within Europe because it was easier for such emigrants to repatriate. Furthermore, in northern industrial Europe, Italian emigrants would be exposed to socialist activism and would begin to develop a sense of political activism and workers' rights.

Economic liberals feared that forced colonization and protectionism would hurt the Italian economy. They preferred spontaneous emigration to the Americas as the best alternative to the problems of the Italian economy and emigration. The development of spontaneous, free colonies, they argued, would lead to the development of free markets for Italian manufactured goods and agricultural products, thus avoiding costly and immoral imperialist adventures. ${ }^{42}$

Idealist liberals favored the establishment of Italian communities in Argentina as part of the process of creating a "greater Italy" or una piu' grande Italia, as the ideal setting where Italian culture, traditions, and values could be transplanted and flourish. The majority of these liberals were intellectuals who had become disheartened with the forces of monarchy and conservativism. They saw their republican ideals vanish and deemed that Argentina represented a way to realize those dreams. ${ }^{43}$

In particular the mayor of Rome, Ernesto Nathan, in 1904 submitted to the Council of Emigration a project for colonization in Argentina that included the purchase of a large piece of real estate. Half would be cultivated by the

\footnotetext{
${ }^{42}$ Ciuffoletti and Degli Innocenti, L'emigrazione nella storia d'Italia , 126-128; Dore, La democrazia italiana, 149-153.

${ }^{43}$ Dore, La democrazia italiana, 129-130.
} 
colonization company and the other half worked by colonists who in time would own the land after paying back a pre-established price. ${ }^{44}$ A similar project, designed by Luigi Scalabrini, provided for the establishment of a stock company that would purchase real estate in the Americas and in Africa. The capital would be raised through the sale of stock and would be guaranteed by the Emigration Fund Committee. ${ }^{45}$

Usually, those who presented plans for Italian colonies abroad demanded the protection of the state. State-directed planning, however, always prompted the suspicion of liberals, who feared that protectionism and colonization might harm the economy and that subsidies to finance "protected" enterprises might lead to speculation that would harm rather than help the emigrant. ${ }^{46}$

In spite of polemics, criticism, and heated debates, the Office of the CGE enthusiastically continued its activities to extend assistance to emigrants, to prevent exploitation and abuse, and to provide information to those who wanted to embark on overseas adventures. One of the distinctive features of the Law of 1901 was that it shifted responsibility for emigration from the Ministry of the Interior to the Foreign Ministry. Ironically, however, it was the Foreign Ministry that often attempted, at times successfully, to limit the powers of the CGE. The Foreign Ministry objected to provisions in the law of 1901 transferring several competencies, responsibilities, and activities (such as legal protection, drafting

\footnotetext{
${ }^{44}$ Ernesto Nathan, “Di un disegno di colonizzazione,” in Nuova Antologia vol. 110 (1904): 537-542.

45 The debate concerning both projects can be found in Atti Parlamentari Camera Deputati, June 26, 1905, 4869-4870.

${ }^{46}$ Manzotti, La polemica sull'emigrazione, 153-155.
} 
and interpretation of treaties, pensions, international conferences for the protection of labor, and public health), from the Ministry to the CGE. In its early years, however, the CGE for the most part performed the same role of supervision and protection, especially in Italy, as the Ministry of Interior had previously done. ${ }^{47}$

In spite of good intentions with regard to its extensive responsibilities, the CGE was not always able to provide adequate assistance to the emigrant abroad because of an insufficient number of officials operating in foreign lands. By 1910, for example, only a few officials worked in other countries, and their role of protection of the emigrant was carried out mostly by consular authorities. As a result, conflicts between consuls and emigration agents were common, for each resented the other's interference in matters they claimed fell under their jurisdiction. ${ }^{48}$

Another controversial issue was the provincial arbitration commissions established by the law of 1901 . These provincial arbitration commissions were located in Italy's main ports. At first, emigrants were suspicious of the commissions but, thanks to the work of the CGE, they gradually came to accept them.

The issue that these arbitration commissions were usually called to address concerned Article 24 of the 1901 law, which made navigation companies

\footnotetext{
${ }^{47}$ Sori, L'emigrazione Italiana, 308-309; Manzotti, La polemica sull'emigrazione, 107; Foerster, Italian Emigration of Our Times, 478-482.

${ }^{48}$ Relazione sui servizi per l'anno 1909-1910, submitted to the Foreign Ministry by the Commissioner General of Emigration Luigi Rossi (Rome: CGE, 1910).
} 
responsible for the emigrant only in the event that the individual was rejected at the landing port. One interpretation of Article 24 for many years was that transport companies were deemed liable only if they knew in advance that the emigrant would be rejected by the receiving country. This restriction favored the shipping company rather than the emigrant. An interpretation of the law more favorable to the emigrant, urged by the CGE, required transportation companies to reimburse emigrants for indirect damages suffered even though the shipping company was deemed not liable. ${ }^{49}$

For the most part, the Commissioner dealt with grievances by emigrants concerning lost luggage, delays in departure, and refusal of entry by United States authorities. The number of complaints was not particularly large, and many of them were not considered. In 1902, for example, of the 162 grievances filed by emigrants, 100 were never considered; 34 were processed, and 28 were rejected. In 1906, out of 623 grievances filed, 353 were pending, 130 were accepted for processing, and 140 were rejected. ${ }^{50}$

Nevertheless, in spite of some of its limitations and shortcomings, the law of 1901 was ground-breaking, a true landmark in the history of Italian emigration. In the words of historian Robert Foerster, it may be considered an epoch-making law that signaled the beginning of a new, more dynamic phase in Italian emigration policy. ${ }^{51}$ Even though the law was amended and modified over the

\footnotetext{
${ }^{49}$ Dore, La democrazia italiana, 93-94.

${ }^{50}$ Relazione sui servizi per l'anno 1909-1910, submitted to the Foreign Ministry by the Commissioner General of Emigration Luigi Rossi (Rome: CGE, 1910).

${ }^{51}$ Foerster, Italian Emigration of Our Times, 477.
} 
years, its fundamental structure remained essentially unaltered until the drafting of the royal decree of November 13, 1919, n. 2205, usually known as Testo Unico or "single law," which included all previous legislation. ${ }^{52}$

The first revision occurred on August 2, 1913, with a law that reformed the role of the arbitration commissions (n.1075). The law gave emigration inspectors the authority to deliberate about money controversies up to the value of 250 lira. Later on, with the law of August 29, 1918 (n. 1379), it was established that only emigration inspectors located in the various boarding ports were in charge of legal grievances for loss or damage. The law also established that, in certain specific cases, it was possible to appeal arbitration commissions' decisions through the normal code of law.

In general, available documents reveal that deliberations on the part of the arbitration commissions tended to be favorable to the shipping companies rather than to the emigrant. There was very little sensitivity on the part of the judges in the application of social laws, as can be seen from contemporary parliamentary documentation as well as from reports submitted to the Foreign Ministry by the Commissioner General of Emigration. ${ }^{53}$ However, because of the inherent characteristics of Italian emigration, such as great numbers of expatriations and lack of a direct link to government-sponsored colonies as in other nations, such laws represented great legislative progress and originality. ${ }^{54}$

\footnotetext{
${ }^{52}$ See Foerster, Italian Emigration of Our Times, 477; Dore, La democrazia italiana, 107; Rosoli, Un secolo di emigrazione italiana, 258; Manzotti, La polemica sull'emigrazione, 156-157.

${ }^{53}$ Giuseppe De Michelis, “L’emigrazione italiana dal 1910 al 1923” (Rome: CGE, 1926).

${ }^{54}$ Manzotti, La polemica sull'emigrazione, 157-158.
} 
One final revision occurred after World War I with passage of the Testo Unico of Emigration Law (13 November 1919, n. 2205), which aimed at reorganizing in one comprehensive law all existing legislation concerning emigration. The Testo Unico conferred more powers on the office of the CGE, allowing it to intervene in foreign countries in a more decisive manner and to guarantee the emigrant's right and freedom to find work abroad. ${ }^{55}$

One of the reasons for passage of the Testo Unico was certainly the role of the CGE during World War I. In fact, during the war, the office of the CGE expanded its tasks. It became responsible for assisting emigrants who wanted to return home to enlist in the army, for mobilization, for maintaining relations with Italian consulates abroad, and for providing necessary documentation to the police for the issuing of passports. ${ }^{56}$

In the early phase of Fascist emigration policy, the leading figure was Giuseppe De Michelis (1872-1951), who served as Commissioner General of Emigration from 1919 until the suppression of his office in 1927. Although he represented a link with the past and had not been part of the "Fascist revolution," the Fascists admired him for his many accomplishments. De Michelis had had a distinguished career. During World War I, he organized civilian manpower at the front and had served as administrator of the displaced persons program. ${ }^{57}$ Moreover, as Commissioner General, De Michelis established the National

\footnotetext{
${ }^{55}$ Dore, La democrazia italiana, 107; Sori, L'emigrazione italiana, 415-416.

${ }^{56}$ Sori, L'emigrazione Italiana, 401-403.

${ }^{57}$ Cannistraro and Rosoli, “Fascist Emigration Policy,” 677; a biographical description of Giuseppe De Michelis can be found in Chi e’? Dizionario degli Italiani di oggi (Rome: Cenacolo, 1940), 328-329.
} 
Institute for Colonization and Labor Abroad (Istituto nazionale per la colonizzazione e le imprese di lavoro all'estero, INCILE) in 1920. The purpose was to direct Italian emigration toward agriculture. With its poor funding, however, the institute did not work very well and was replaced with the Credit Institute for Italian Labor Abroad (Istituto di credito per il lavoro italiano all'estero, ICLE), an agency that included capital and investments by navigation companies, banks, and insurance and finance institutions. A few projects sponsored by this agency were quite successful in the following years. ${ }^{58}$

In spite of its excellent performance during wartime, in the immediate postwar period, the CGE came under criticism, especially by members of the Partito Popolare (i.e., Catholic Party, the nucleus of the future Democrazia Cristiana), which advocated changes in the Italian emigration policy that would reclaim for the mother country its lost children. Among the main critics was deputy Stefano Jacini, a strong supporter of the Opera Bonomelli, which for several decades had been providing aid and comfort to Italian emigrants in Europe. A fervent Catholic, Jacini claimed that the CGE had come under socialist influence. Such criticism was not directly aimed at Giuseppe De Michelis, CGE's long- time leader, who had come to personify the CGE itself, but at its subagencies such as the Council of Emigration and the Parliamentary Vigilance Committee, which had come under the influence of various interest groups, including socialists. ${ }^{59}$

\footnotetext{
${ }^{58}$ Sori, L'emigrazione italiana, 414-415.

${ }^{59}$ Manzotti, La polemica sull'emigrazione, 147-148.
} 
Eventually it was Benito Mussolini who curtailed the powers of the CGE. Following the war, the migratory flux was greatly diminished, as the traditional destination countries were introducing measures curtailing the entrance of additional foreign workers. In particular, in the United States a defense of the American labor market together with protectionism and social prejudice led to the establishment of a quota system. This policy began with the Immigration Act of 1921, that curtailed immigration from southern and eastern Europe--the so-called "new" immigration. In 1921 Italian emigration to the United States was reduced to 114,912 (compared to 408,104 in 1920), and, in 1925, to 96,435 because of further restrictions imposed by the Johnson Act of $1924 .^{60}$

The dwindling number of departures gave the Fascist government the opportunity to argue that Italy was doing well, and that Italians no longer needed to emigrate to earn a living. Thus, Mussolini abolished the CGE on April 26, 1927, replacing it with the General Bureau of Italians Abroad (Direzione Generale Italiani all'Estero), a more political organ that could more easily be linked with the Fasci all'estero (Fascist clubs abroad), some of which had already been established before the March on Rome (October 28, 1922). Like the CGE, the Bureau of Italians Abroad was placed under the jurisdiction of the Foreign Ministry. Also abolished were both the Council of Emigration and the Committee for Funding Emigration. At the same time, the consular network was increased

\footnotetext{
${ }^{60}$ For a discussion of the U.S. laws of 1921 and 1924, please refer to Chapter II, pp. 32- 34. For figures of expatriates from Italy in the period 1920-1927, please see Gianfausto Rosoli, Un secolo di emigrazione italiana (Rome: Centro Studi Emigrazione, 1978), 346. This work remains the best and most reliable source for a quantitative analysis of Italian emigration.
} 
with the infusion of men faithful to the regime. ${ }^{61}$ The decree that established the Direzione Generale also included a provision to abolish the "red passport" that had been introduced with the Testo Unico of 1919, a passport that automatically defined the emigrant as such because of the different color passport. Another decree of June 21 1928, n. 1710, declared that the passport was the only document for all citizens who went abroad for whatever reason. Emigrants should not be marked or labeled by a different color passport. The provision was consistent with Fascist ideology and the Duce's claim that Italy was a country of superabundant energy rather than a country whose citizens were forced to emigrate because of a lack of resources. ${ }^{62}$

Although Fascist rhetoric claimed credit for the decline in emigration flow, in reality Mussolini and his associates were not able to eradicate the original causes of emigration, nor were they able to erase the injustices that usually accompanied it. One could argue that the war, not fascist policy, had been responsible for the decline in emigrants' departures. ${ }^{63}$

The regime did, however, gradually develop a new approach to emigration that included a redefinition of what it meant to be an emigrant and what the relationship between the emigrant and Italy should be. The Duce considered emigration a fundamental necessity, but he wanted to regulate it and, especially, to make it temporary and not permanent. He also emphasized that one positive

\footnotetext{
${ }^{61}$ Cannistraro and Rosoli, “Fascist Emigration Policy,” 678-679.

${ }^{62}$ Ibid.

${ }^{63}$ Ercole Sori, “Emigrazione all'estero e migrazioni interne in Italia fra le due guerre,” Quaderni Storici, X, (1975): 579-606; Annunziata Nobile, "Politica migratoria e vicende dell'emigrazione durante il fascismo," Il Ponte, XXX (1974): 1322-1335.
} 
aspect of emigration must be to use emigrants as instruments to raise the general esteem of Italians abroad, who often were victims of prejudices that reflected adversely on the overall image of Italy. ${ }^{64}$

Until the suppression of the Commissioner General of Emigration, which signaled a major change in Fascist emigration policy, Mussolini's primary goal had been to bring emigration under government regulation. One instrument he employed to reach this goal was Fasci all'estero, a network of fascist clubs outside Italy that provided assistance to Italian nationals abroad. Mussolini hoped to spread Fascism abroad and improve the image of Italians in other lands through a network of fascist clubs outside Italy. To coordinate their activities, Mussolini established the Fasci Abroad Secretariat (Segreteria dei fasci all'estero) and appointed Giuseppe Bastianini to lead an ideological fascist crusade. ${ }^{65}$ On the occasion of the first congress of the Fasci all'Estero, Giuseppe De Michelis wrote in Gerarchia, the official fascist publication, that the resumption of Italian emigration was a policy of the regime. He also emphasized the need to improve the actual process of emigration. ${ }^{66}$

Besides establishing Fasci in Europe, the fascist regime looked to North America with its large Italian community as fertile soil for the preservation of Italiannes and the spread of Italian culture as well as fascist ideology. Mussolini's appeal to the Italians residing in America to preserve italianitá also served the

\footnotetext{
${ }^{64}$ Cannistraro and Rosoli, “Fascist Emigration Policy,” 680.

${ }^{65}$ Alan Cassels, Mussolini’s Early Diplomacy (Princeton: Princeton University Press, 1970), 195-196. Documenti Italiani, Mussolini’s private secretariat, 186/1200/087176.

${ }^{66}$ Bollettino dell’Emigrazione, no. 11 (Rome, 1925): 18-51.
} 
purpose of spreading Fascist ideas. Not only did fascist clubs spring up in America, but older Italo-American societies were also transformed into Fasci in the months following Mussolini's rise to power in 1922. As Alan Cassels points out, the United States was given prime attention as can be deduced from a file in Mussolini's propaganda ministry, Ministry of Popular Culture (Ministero della cultura popolare), which the Allies found at the end of World War II. ${ }^{67}$

From the start, the establishment of Fasci in the United States provoked friction between Rome and the Italian ambassador to Washington, Gelasio Caetani, an experienced diplomat of the pre-fascist era, who continuously advised Mussolini to be cautious. He claimed that the American press usually depicted Italians as dangerous subversives and criminals, and he advised that any attempts to spread fascist ideology would hurt rather than help the Italian image in America. However, in spite of Ambassador Caetani's misgivings, there were fascist enthusiasts on both sides of the Atlantic. A look at documents of the Fasci Abroad Secretariat (Secreteria of the Fasci all'estero) reveals that the main obstacle to the spread of fascist ideology in America was Italian diplomats, especially the Italian ambassador to Washington, with their hostility and poor attitude. ${ }^{68}$

In Italy, the Fascists accused the liberal former governments of having allowed emigration without taking into consideration the dignity of the nation or the demographic and economic effects of emigration. The fascist regime,

\footnotetext{
${ }^{67}$ Alan Cassels, Mussolini’s Early Diplomacy, 196.

${ }^{68}$ Cassels, Mussolini’s Early Diplomacy, 197; Documenti Italiani, Ministry of Popular Culture, 31/429/014-665-70/014713-19014735-36.
} 
instead, welcomed the potential opportunities to raise the general esteem of Italians living abroad, who were often looked down upon and subjected to prejudice. That prejudice reflected negatively on the prestige of the nation as a whole. Mussolini interpreted the 1920s immigration restrictions and quota system of the United States as a "condition of tyrants" and sought to develop alternative approaches, such as Italian colonization projects, international cooperation, and emigration treaties. Indeed, emigration had to be protected and regulated.

Alternative approaches were one of the main issues discussed at the International Conference on Emigration and Immigration that took place in Rome May 15-24, 1924. On that occasion, Mussolini announced, "It is time that the agreements for international protection of workers be joined to economic agreements settling the exchange of resources." ${ }^{69}$ He proposed the creation of international mechanisms for the protection of workers as well as trade agreements settling the exchange of resources. The conference approved several resolutions that reflected the new tendencies of Fascist emigration policy. They included assistance for the emigrant prior to departure, during the journey, and after arrival, along with agreements for cooperation to regulate emigration and immigration as well as labor contracts. ${ }^{70}$

Three main themes were expressed at the 1924 conference in Rome: (1) moral and material assistance to emigrants by private and state agencies before

\footnotetext{
${ }^{69}$ La conferenza internazionale dell'emigrazione e dell'immigrazione, March 15-31, 1924 (Rome: CGE, 1924), 8-11.

${ }^{70}$ Ibid.
} 
their departure, during the journey, and upon arrival; (2) the need for increasingly intimate cooperation to regulate the flow of emigration and immigration; (3) the formulation of general principles upon which to base emigration and labor treaties. ${ }^{71}$ The conference, however, did not succeed in diminishing and diffusing the anti-immigrant trend so strong in the United States, nor did it succeed in overcoming suspicion and protectionism. Ultimately Italian leadership was so ineffective against quotas that the fascist regime was forced to hide its lack of power behind rhetoric. ${ }^{72}$

Official fascist rhetoric linked demographic vitality, expansionism, and imperialism. Fertility, Mussolini maintained, distinguished the Italian people from any other European peoples because "it would show their vitality and willingness to transmit this vitality into the future undiminished." ${ }^{73}$ Fascist population theory was based on the view that emigration could be an important channel of demographic expansion and must not result in the loss of Italian nationality. This concept was particularly important in the United States, where the government always emphasized the "Americanization" of the immigrant and put pressure on all ethnic groups to assimilate into American society. Contrary to American customs and laws insisting that loyalties of naturalized citizens be directed to the United States, the fascist government fought vigorously to maintain as many legal and political ties as possible with Italian emigrants. The regime, for

\footnotetext{
${ }^{71}$ Ibid., doc. no. 22, 41-45.

${ }^{72}$ Cannistraro and Rosoli, “Fascist Emigration Policy,” 682.

${ }^{73}$ Riccardo Korherr, Regresso delle nascite, morte dei popoli (Rome: Libreria del Littorio, 1928), 23.
} 
example, continually insisted on the emigrant's obligation to do military service in Italy. ${ }^{74}$ Although Mussolini's change of policy was in line with fascist doctrine, it was also in part the result of changes by other countries aimed at immigration's restriction and protectionism.

Following the suppression of the Commissioner General of Emigration in 1927 and the establishment of the Bureau of Italians Abroad, the Foreign Ministry shifted the responsibility for protection and assistance of Italians abroad to the Fasci all'Estero. For the Fascist regime, the Fasci had become an integral part of emigration policy. However, the problem of protecting Italian nationals persisted and remained an issue with which Italian diplomatic representatives abroad and politicians continued to struggle.

From the liberal government to the fascist government, in spite of passage of laws to regulate emigration and to prevent abuse of the emigrant prior to departure, Italian politicians and diplomats had to deal with the problem of protecting Italian nationals abroad. By the late 1800 s, the United States had become the greatest destination of Italian emigrants. The United States represented the promise of a brighter future, but also the fragility of that dream. In the United States, Italian laborers were valued but disliked; they were subjected to discrimination, harassment, violence, and even lynching. Numerous episodes of violence and even lynching of Italians occurred in the late 1800 s and early 1900s. In most cases, the violence went unpunished by the local authorities, regardless of the innocence or guilt of the victims. Representatives of

\footnotetext{
${ }^{74}$ Claudia Belleri Damiani, “L'emigrazione italiana negli Stati Uniti durante il periodo fascista,” Affari Sociali Internationali (special issue) (1978): 117-118.
} 
the Italian government in the United States protested vigorously the federal government's failure to protect Italian nationals on U.S. soil according to existing treaties. However, Italian diplomats usually pursued a course of prudence and moderation and--except for the case of New Orleans, which provoked a serious diplomatic crisis and national pride in the Italian Parliament, culminating in Rome's recall of its ambassador--they made efforts to maintain good relations between Italy and the United States. 


\section{CHAPTER IV}

ANTI-ITALIAN SENTIMENT IN THE UNITED STATES: HARASSMENT, VIOLENCE, AND LYNCHING IN THE LATE 1800s

By the late 1800s the United States was the greatest destination of Italian emigrants. The United States represented for them not only the promise of a brighter future but also the fragility of that dream. In fact, the image of Italians in America was contradictory and complex. In North America, employers considered Italians industrious individuals, but held them in low esteem. On the other hand, American laborers resented Italian workers who were willing to accept jobs for lower wages. Dislike turned into a sense of threat that swelled into violence. Indeed, Italian immigrants were among the frequent victims of ethnic hatred and lynch mobs throughout the United States. In most cases, the violence went unpunished by the local authorities regardless of the innocence or guilt of the victims. Italian diplomats protested vigorously the federal government's failure to protect Italian nationals working on U.S. soil in accordance with existing treaties. However, Italian representatives and politicians who dealt with these episodes of violence made efforts not to disrupt relations between Italy and the United States and adopted an attitude of prudence and moderation--except for the New Orleans lynching of 1891, which provoked a serious diplomatic crisis and national pride in the Italian Parliament, culminating in Rome's recalling its ambassador.

In the climate of high xenophobia sparked by the "new immigration" of the late nineteenth and early twentieth centuries, Italian immigrants were seen as 
dangerous subversives, anarchists, and troublemakers; yet these immigrants were also valued as a source of cheap, unskilled labor always ready to accept a job for lower wages. Anti-Italian sentiment was rooted deeply in racism, ignorance, and economic fears. Count Gerolamo Moroni, the Italian vice consul in New Orleans, wrote that American employers considered Italians "working animals," much "desired but not loved." ${ }^{1}$ The American workers, on the other hand, resented Italians because they would work for lower wages. Both American employers and workers disparaged Italians and their culture, considering them part of an inferior race. ${ }^{2}$ Italians, in fact, were often compared to blacks, especially in the South, as Italians tended to be quite friendly to blacks and as Italian males often lived with black women as man and wife, a practice that was particularly repugnant to white men in the South. ${ }^{3}$

.Although not all episodes of lynching presented the same characteristics, one can detect one common denominator. Usually the individual to be lynched was taken from legal custody, that is, taken away from the responsibility of local authorities; the individual then was executed, either outside or inside the prison, by people generally deemed to be honest citizens aiming to defend traditional values of the community from foreigners who were considered corruptors of American society and culture. Other than a few exceptions of a political nature, such as the lynching of Donato Carretta, director of Regina Coeli prison in Rome,

\footnotetext{
${ }^{1}$ Gerolamo Moroni, "L'emigrazione italiana nel distretto consolare di New Orleans," in Bollettino dell'Emigrazione, no. 16 (Rome, 1908), 25

${ }^{2}$ Ibid.

${ }^{3}$ Ibid.
} 
Italy, during World War II, one cannot say that lynching is a part of Italian and European history and tradition. It is no accident that, following the lynching of Italians in Tampa, Florida, in 1910, Count Gerolamo Moroni, Italian emigration representative at the Italian consulate in New Orleans, pointed out that lynching was mostly unknown to Italians and that perhaps someday, Italian emigrants would learn about it from American citizens. ${ }^{4}$

Usually an episode of lynching involved pre-meditated planning and organization. Lynchings that occurred in the United States were not spontaneous acts of mob violence; they were planned. They were not uncontrolled explosions of mass hysteria and rage. Lynchings were prompted by a perceived need to make an example of an individual in order to protect and defend the community. It would be incorrect to deem an episode of lynching as a private vendetta to right wrongs. It was, indeed, an act purported to defend the community, an act accomplished by the community itself in supposed self-defense, according to a classical ritual of violence justified by the common good. ${ }^{5}$

Although lynchings occurred in numerous states, they were vastly more frequent in the South, where the black population was harassed and racial

\footnotetext{
${ }^{4}$ ASDMAE, Serie Politica “Z,” USA, pacco 33, pos.27/2. From the Consulate of Italy, New Orleans to MAE, 8 October 1910.

${ }^{5}$ The extensive literature on this phenomenon includes the following works: James E. Cutler, Lynch-Law: An Investigation into the History of Lynching in the United States (New York: Arno Press, 1969); Ida B. Wells-Barnett, On Lynchings: Southern Horrors, A Red Record, Mob Rule in New Orleans (New York: Arno Press, 1969); Walter White, Rope and Faggot (New York: Arno Press, 1969); John Higham, Strangers in the Land: Patterns of American Nativism 1860-1925 (New Brunswick: Rutgers University Press, 1955); R.P. Ingalls, Urban Vigilantes the New South: Tampa 1882-1936 (Knoxville: The University of Tennessee Press, 1988); E.L. Ayers, The Promise of the New South (New York: Oxford University Press, 1992); W.F. Brundage, Lynching in the New South: Georgia and Virginia, 1880-1930 (Urbana: University of Illinois Press, 1993); S.E. Tolnay, A Festival of Violence: An Analysis of Southern Lynchings, 1882-1930 (Urbana: University of Illinois Press, 1995); P. Dray, At the Hands of Persons Unknown: The Lynching of Black Americans (New York: Modern Library, 2003).
} 
tensions were most intense. Lynchings occurred most frequently during the summer, provoked usually by an increase in social-economic tensions between landlords and black laborers rather than by mere hot weather. ${ }^{6}$ But whenever the lynching occurred, the act was not treated by public officials as a serious crime. Lynchings usually provoked some futile and isolated protest, but not passage of effective laws against them. ${ }^{7}$

According to Italian Ambassador Edmondo Mayor de Planches, lynch mobs were usually made up of simple, rude, ignorant--albeit honest--citizens. However, it was not rare to encounter educated, cultured individuals of the upper classes among the mobs. Like their less educated compatriots, these individuals tended to justify the crime as a legitimate act of social justice committed against disreputable individuals who had been a threat to the community, but who had avoided punishment. ${ }^{8}$

Lynching was not simply an expression of lack of confidence in the institutions of justice. It was also a tool of social control against groups, both native and foreign, that communities either feared or loathed. Hence, lynchers could usually count on the connivance of the authorities-judges, sheriffs, police, and jail guards - thus making legal an illegal act and turning it into a legitimate practice of "popular justice" aimed at communities' self-defense. ${ }^{9}$

\footnotetext{
${ }^{6}$ ASDMAE, Serie Politica "P” (1891-1916), pacco 683, pos. 888. From the Italian Embassy at Washington, D.C. to MAE, 30 June 1905; Cutler, Lynch Law, 165.

${ }^{7}$ ASDMAE, Serie Politica “P” (1891-1916), pacco 683, pos. 882. From Italian Embassy, Manchester, Mass. to Italian Foreign Minister Prinetti, 2 August 1902.

${ }^{8}$ Ibid.

${ }^{\dot{9}}$ Ibid.
} 
It is not surprising that numerous episodes of violence and even lynching of Italians occurred in the United States in the late nineteenth and early twentieth centuries. Usually violence, harassment, and murder went unpunished by the local authorities. One of the first cases that attracted the attention of Rome occurred in 1879 in Eureka, Nevada, a prosperous silver-mining town. Italian and Italian-Swiss immigrants were brought to Eureka for their expertise in producing charcoal from wood, a commodity necessary for milling silver ore. In spite of their vital contribution to the mining operation, charcoal burners were paid only half the wages of miners. Since they did not speak English very well, they were often cheated in transactions by the teamsters and middlemen who transported the finished charcoal to the smelting mills. ${ }^{10}$

In 1879, with the price of charcoal at twenty-eight cents per bushel, a group of Italians belonging to the Charcoal Burners Association called a strike, demanding a two-cent increase in wages. In a detailed report written after the episode, Count Diego Lorenzo Barillis, the Italian consul in San Francisco, wrote that the worsening working conditions had provoked uneasiness and even exasperation among workers and that hot-headed agitators had urged protesters

\footnotetext{
${ }^{10}$ According to the census of 1870, there were only 300 Italians in the whole State of Nevada. Established in 1864, the Mining District of Eureka, Nevada, saw a continuous population growth. According to the census of 1880, the Italian charcoal burners or Carbonari counted for $12 \%$ of the 9,000 in Eureka, the center of charcoal production. It must be noted that exact data are not available because Italian charcoal burners were scattered in the surrounding areas and there were both Italians and Swiss Italians and it is difficult to tell from the last names whether these charcoal burners were Italian or Swiss. See also Philip I. Earl, “Nevada's Italian War," Nevada Historical Society Quaterly, volume XII, no.2 (Summer 1969): 4787.
} 
to block the road running across the mountains in order to forestall charcoal being transported to town. ${ }^{11}$

Tension between strikers and the local authorities increased on August 18, 1879 when Sheriff Matt Kyle detained several individuals he deemed dangerous and arrested suspected leaders of bands blocking charcoal transportation to town. Several of the names appearing on the arrest warrant were fictitious because the authorities did not know the real names. With charcoal supplies to the mines cut off, tensions between strikers and the authorities escalated. The sheriff's deputies fired on workers without apparent provocation, leaving five men dead, six injured, and several strikers jailed. ${ }^{12}$

Shortly after the violence Barillis and consular agent Luigi Monaco informed Ambassador Baron Albert Blanc in Washington that several Italians had improperly participated in the violence, but that only three of the sixteen strikers arrested were armed, implying that the local police might have overreacted and exceeded their authority. ${ }^{13}$

Of the five strikers killed, two were Italian, while none of the deputies were killed or injured. All sworn testimonies gathered by Barillis reported that the police started shooting without any warning, while the police report concluded that the deputies fired only after hearing a shot. Barillis urged the ambassador to demand an indemnity for the dead Italians' families, based on his assumption

\footnotetext{
${ }^{11}$ Ibid.

${ }^{12}$ ASDMAE, From Italian Embassy at Washington (1861-1901), pacco 35, pos. 60.

${ }^{13}$ Ibid., 22 August 1879.
} 
that the deputies involved in the shooting would be exonerated in the upcoming coroner's report. ${ }^{14}$

As expected, the coroner found that the deputies had killed the Italians legally and in the performance of their duties. Also as Barillis had anticipated, the district attorney refused to indict any of the law enforcement officers claiming that, given the coroner's report, the district attorney claimed a trial would merely place an unnecessary financial burden on the town. Barillis also saw no necessity for a trial, since the Italians could not afford to pay an attorney. Besides, the mood of the local citizens was such that a fair trial could not be guaranteed. Barillis was worried about the Italians but urged them not to do anything irresponsible, while he continued to pursue the help and support from the Italian government. ${ }^{15} \mathrm{~A}$ few months after the shooting, the grand jury issued a final report that exonerated the sheriff and his men, relieving them of any responsibility related to the incident. ${ }^{16}$

Another lynching episode occurred in Vicksburg, Mississippi, on March 25, 1886. According to available sources, an Italian man, Federico Villarosa of Palermo, Sicily, owner of a fruit and vegetable store, was charged with raping a ten-year-old American girl. Villarosa was taken to the county jail, where the sheriff, fearing for the Italian's life, requested and received protection for the prisoner from state militia. In spite of that, fifty to seventy local citizens, probably

\footnotetext{
${ }^{14}$ Ibid., 23 August 1879.

${ }^{15}$ Ibid., 4 September 1879.

${ }^{16}$ Ibid., 20 December 1879.
} 
with the connivance of the prison guards, broke into the jail, abducted the unfortunate Villarosa, and hanged him from a tree. ${ }^{17}$

Initially, The Vicksburg Evening Post praised the sheriff's attempt to prevent the lynching, but did not condemn Villarosa's hanging, choosing to report it simply as a fact. On the other hand, the Italian newspaper II Progresso ItaloAmericano of New York protested the barbaric act vigorously, stating that the hanging of an individual before trial in a court of law to ascertain his guilt or innocence made Villarosa a martyr. ${ }^{18}$ The newspaper set in motion an inquiry based on the testimony of consular agent Natale Piazza, who had expressed doubts about Villarosa's guilt. In fact, the medical examination of the little girl had revealed that she had not been raped, though she had been molested. Indeed, Villanova had been drunk and had acted in a very improper manner, but he had not raped the girl. Racism and a general dislike of Italians had condemned Villarosa to hanging without a trial. As the Progresso Italo-Americano noted, "ethnic discrimination wanted him dead at all cost more because of revenge than for justice." ${ }^{19}$ In fact, the newspaper reported that the actual hanging had occurred in darkness, whereas usually lynchings took place either in broad daylight or, if at night, with light from torches and fires. ${ }^{20}$ The newspaper urged Rome to take action and proposed that the Italian ambassador, Baron Francesco

\footnotetext{
${ }^{17}$ ASDMAE, Italian Embassy in Washington (1848-1901) pacco 59, pos.711; from consular agent at Vicksburg to Royal Consul General at New York, 30 March 1886.

18 "Il linciaggio del Villarosa a Vicksburg, Miss.” in Il Progresso Italo-Americano, 2 April 1886.

19 “Ancora del linciaggio dell’italiano a Vicksburg, Miss.” in Il Progresso Italo-Americano, 3 April 1886.

${ }^{20}$ Ibid.
} 
Saverio Fava, lodge a formal protest with Secretary of State Thomas F. Bayard $(1885-1889) .{ }^{21}$ Nothing came of the protest, except perhaps a lingering resentment of Italians in Vicksburg. In fact, one year after Villarosa's lynching, the Progresso Italo-Americano reported that, in the Mississippi town, Italians continued to be victims of insults and "unconceivable provocations."22

It is likely that, besides ethnic hatred, the dislike of Italians in Vicksburg stemmed from economic competition. In 1887, for example, the Progresso ItaloAmericano reported that when a group of Italian workers passed through the town on their way to Alabama to work on railroad construction, local inhabitants assumed that the Italians had come to steal their jobs. ${ }^{23}$ According to the newspaper, the American press had contributed "to the rise of hatred and despise of Italians, depicting them as thieves and usurpers of jobs, placing them at a level lower than the Chinese in the social ladder." The newspaper also criticized Rome and its officials in the United States for failing to offer effective protection to their nationals. ${ }^{24}$

Still another act of violence against Italians occurred in Louisville, Kentucky, in 1889 with the lynching of two brothers. The newspaper L'Italia of San Francisco reported that in the valley of Cumberland Gap, in a camp of Italian workers, two Italian bakers, Antonio Cravasso and his brother, had sold bread to

\footnotetext{
${ }^{21}$ Ibid.

22 “Ancora per la difesa dell'onore e per la pace della colonia di Vicksburg," in Il Progresso ItaloAmericano, 18-19 April 1887.

${ }^{23}$ Ibid.

${ }^{24}$ Ibid. 17 April 1887.
} 
the workers and had not been paid. The Cravasso brothers asked George W. Norwood, a contractor from Birmingham, Alabama, to deduct the money owed to them from the workers' salaries, but Norwood refused. After a second attempt to collect their money failed, Norwood and the two brothers had an altercation, and Antonio Cravasso took out his gun and killed Norwood. The Cravassos were arrested by the police and sent to the prison at Pineville, Kentucky, but while en route, outraged local citizens took the brothers by force, hanged Antonio, and shot and killed his brother. ${ }^{25}$ A month later, the Italian chargé d'affairs at Washington wrote to the Italian consul general in New York, Giovanni Paolo Riva, thanking him for having provided through the Governor of Kentucky, Simon B. Buckner (1887-1891), the report by the judge of Bell County concerning the Cravasso's lynching. He ended his note with the usual formula, saying that he hoped that the request for information might turn into an inquiry by the local authorities so that the lynchers would be brought to justice. ${ }^{26}$

The most dramatic episode of lynching of Italians in the United States occurred in New Orleans, Louisiana, in 1891. This episode was the most serious not only because of the violence and ferocity of the lynching itself, but also because, of the eleven dead Italians, eight were already naturalized American citizens and the other three were Italian citizens. Scholars on both sides of the Atlantic have studied this case not just because of its gravity and ferocity, but because it led to an important change in U.S.-Italian diplomatic relations. In fact,

\footnotetext{
${ }^{25}$ L'Italia, 25 June 1889.

${ }^{26}$ ASDMAE, Italian Representative at Washington (1848-1901), pacco 59, pos. 734. From the Italian Embassy at Washington to the Consulate at New York, 2 August 1889.
} 
after the lynching at New Orleans, the Italian government became more assertive in demanding that lynchers be brought to justice, as well as in requesting better protection for Italian citizens who resided and worked in the United States. The episode engendered a one-year diplomatic controversy, culminating in the recall of the Italian ambassador in Washington. ${ }^{27}$

The immediate cause of the lynching was the assassination of the New Orleans Chief of Police, David C. Hennessy, on 15 October 1890. The investigation that ensued was conducted mostly within the New Orleans Italian community, which included about 30,000 Italians. Hundreds of Italians were arrested on suspicion of complicity in the murder. Writing to Baron Fava, the Italian Ambassador to Washington, Pasquale Corte, the Italian Consul in New Orleans, depicted the methods adopted by the local authorities in investigating the murder as questionable. Corte reported that a vigilante committee had been formed, with the connivance of the Mayor of New Orleans, Joseph A.

Shakspeare, in order to eradicate the Italian Mafia. Responding to the protest of ambassador Fava, the Governor of Louisiana, Francis T. Nicholls, assured Fava that the Italian community was not in any danger. In fact, the trial ended with the acquittal of the accused, probably because the jury had been corrupted, thus angering the New Orleans population. ${ }^{28}$

\footnotetext{
${ }^{27}$ Two good studies of the New Orleans lynching are Richard Gambino, Vendetta (Garden City, New York: Doubleday, 1977) and Marco Rimanelli and Sheryl Lynn Postman, The 1891 New Orleans Lynching and U.S.-Italian Relations: A Look Back (New York: Peter Lang, 1992).

${ }^{28}$ ASDMAE, Serie Politica “P” (1891-1916), pacco 445. From the Italian Consulate at New Orleans to the Italian Embassy at Washington, 15 March 1891.
} 
An examination of the correspondence between the Italian consulate in New Orleans, the Italian embassy in Washington, the U.S. Department of State, and the governor of Louisiana shows that the lynching of the Italians occurred with the connivance of the New Orleans local authorities. ${ }^{29}$ Corte followed the case with zeal. He was very competent, passionate, and scrupulous, but at times he could be "undiplomatic," especially toward the local American authorities. His own collaborators deemed him unfit for the delicate task facing him and at times even "out of control." ${ }^{30}$ The day after the lynching, he wrote to Fava: "I have no time now to describe the horrors of the genocide that the populace led by the leaders of the vigilante committee has committed against eleven harmless prisoners who had been acquitted." ${ }^{31}$

It is true that many Italians who lived in New Orleans did not have good reputations, nor did they have clean records. Most of the lynching victims were not exactly model citizens. The Italian Foreign Minister, Marquis Antonio di Rudinì, sent the Italian ambassador in Washington a list of the Italians and a description of their backgrounds. Antonio Marchese, whose real name was Antonio Grimando, had been in trouble with the law in Italy; Emanuele Polizza was a known member of the Italian Mafia, although never indicted for any crime; Rocco Geraci had emigrated from Italy to escape the Italian authorities; and Loreto Comitis had been indicted three times in Italy. However, some of the New

\footnotetext{
${ }^{29}$ ASDMAE, Ibid.

${ }^{30}$ ASDMAE, Ibid.

${ }^{31}$ ASDMAE, Ibid.
} 
Orleans victims had never been in trouble with the law and had clean records: Antonio Abbagnato, Girolamo Caruso, Pietro Monastero, Antonio Scafidi, and Vincenzo Traina. ${ }^{32}$

Indeed, Corte was well aware that the Italian community in New Orleans had a bad reputation, that during the trial the jury had been bribed, and that the people of New Orleans were enraged. However, bad reputation alone, according to Corte, did not justify such a brutal and violent reaction. Even though the consul did not overlook the exasperation of New Orleans, he was concerned about the activities of the vigilantes' committee that had formed soon after the verdict, as well as the role of the local authorities. As he wrote to the Italian ambassador, he could not understand why members of the higher classes had engineered such a cruel and violent murder. He could understand even less the connivance of local authorities: they made no effort to stop the infamous episode of violence, but had consented to it and might even have instigated it. ${ }^{33}$

According to Corte, the possibility of bloody violence had been discussed openly and could have been anticipated. The day after the verdict, local newspapers such as the Daily States and the Delta published news of a meeting of the "Committee of the Fifty," the newly forged vigilantes' committee to right wrongs and to correct the verdict. The blood bath could have been prevented, Consul Corte maintained, had the prisoners been moved during the night to another jail. He tried in vain to confer with the mayor, Joseph A. Shakspeare,

\footnotetext{
${ }^{32}$ ASDMAE, Ibid. From MAE to Italian Embassy at Washington, 25 July1891.

${ }^{33}$ ASDMAE, Ibid. From the Italian Consulate at New Orleans to the Italian Embassy at Washington, 15 March 1891.
} 
who was nowhere to be found. Corte also attempted to talk to Louisiana governor Francis T. Nicholls, who claimed that he could not do anything without the mayor's requesting it. While waiting to meet the mayor, Corte was informed that the mob had broken into the prison and had hanged three of the prisoners. Corte went immediately to the jail and saw eleven dead bodies hanging from the trees. He returned to the consulate, where he fought off three black men who attempted to attack him by showing them his gun. The consular secretary, pale and scared, told Corte that he had heard the crowd screaming, "Kill the Italians," so he had taken refuge in a storage room. ${ }^{34}$

When ambassador Fava learned of the massacre, he appealed to U.S. Secretary of State James G. Blaine, asking for serious action on the part of the United States government. Also, Italian Foreign Minister Antonio di Rudinì instructed Fava to file a formal protest with the U.S. government, demanding protection of Italian subjects based on existing treaties and the immediate punishment of those who had committed or instigated the murder. Fava wrote the following to U.S. Secretary of State Blaine (Washington, 15 March 1891):

Mr. Secretary of State, I must protest in the most solemn manner against the unjustifiable conduct of local authorities, who not only did not prevent a meeting which was publicly announced the day before, and which left no doubts as to its hostility to the Italians, but who maintained a purely passive attitude, while the massacre of Italians was going on in the prison. ...

Reserving. ... the right to demand. ... any other reparation. . . .deemed proper, allow me. ... to rely upon the traditional friendship which always existed between our two countries. . . while I invoke the aid and

\footnotetext{
${ }^{34}$ ASDMAE, Ibid. From the Italian Consulate at New Orleans to the Italian Embassy at Washington, 15 March 1891.
} 
cooperation of the Federal administration to. . . .end this regrettable incident. . . . ${ }^{35}$

Fava appealed to Secretary of State Blaine to intervene with the Louisiana state authorities so that Italians would be protected and so that perpetrators, accomplices, or instigators of the massacre would be brought to justice. However, in the days following the lynchings, martial law was never declared, no troops were deployed, nor were the vigilante leaders arrested. Instead, in spite of strong pressure from the State Department and from the Italian Foreign Ministry, Governor Nicholls wrote Secretary Blaine that all was quiet in New Orleans. ${ }^{36}$ Historically, the Italian government had always cooperated with the United States in matters concerning emigration. Following the lynchings, Italy persisted in appealing to the "protection principle" included in a treaty signed by the two countries in 1871, which mandated equal protection for citizens of each country under local law. Although Washington and Rome disagreed on the number of Italian citizens who had been lynched (eight of them were naturalized American citizens), the U.S. government accepted the "protection principle" and tried to persuade the Louisiana authorities to take legal action. ${ }^{37}$ However, it could be difficult to fault Nicholls, since the Constitution of the United States mandates the separation of powers, including the powers of federal and state governments,

\footnotetext{
${ }^{35}$ Foreign Relations of the United States (FRUS), 51st Cong., 2nd sess., 1891 (Washington G.P.O.,1892), 666-667.

${ }^{36}$ Ibid.

${ }^{37}$ Rimanelli and Postman, The 1891 New Orleans Lynching and U.S.-Italian Relations, 146-147.
} 
regardless of any foreign treaties negotiated by the federal government with foreign countries.

Secretary of State Blaine responded to Governor Nicholls (Washington, 15

March 1891) with these words:

.... Among the victims of the deplorable massacre which took place in the city of New Orleans yesterday were three or more subjects of the King of Italy. Our treaty with that friendly government guarantees to the Italian subjects domiciled in the United States the most constant protection and security for their persons and property, making them amenable, on the same basis as our own citizens, to the laws of the U.S. and of several States, in their due and orderly administration. ...

The Government of the United States must give to the subjects of friendly powers that security which it demands of our own citizens when temporarily under a foreign jurisdiction. ${ }^{38}$

Fava was aware that Washington was embarrassed about the New Orleans lynchings and that, based on the U.S. Constitution, was in a very delicate position concerning the authority of a state trying to protect its own powers, authority, and jurisdiction in a strong federal system. ${ }^{39}$ Concerning Blaine's telegram to Nicholls, Fava appreciated Secretary's Blaine's words and wrote to Foreign Minister Rudinì that the telegram should be interpreted as a sign of deference toward His Majesty's government. Fava also informed Rudinì that Secretary Blaine had made it clear, during a conversation that his government would be amenable to paying an indemnity to the families of the three slain Italians and that such a request would be accepted by Congress. ${ }^{40}$

\footnotetext{
${ }^{38}$ FRUS, 51st Cong, 2nd sess. 1891, Telegram by Secretary Blaine to Governor Nicholls, 15 March 1891, 666-667.

${ }^{39}$ The problem of dualism of the U.S. Constitution, federal intervention in state affairs and international treaties is dealt with in Chapter VI.

${ }^{40}$ ASDMAE, Serie Politica “P” (1891-1916), from the Italian Embassy at Washington to MAE, 16 March 1891.
} 
The New Orleans lynchings provoked humiliation, anger, and resentment among the Italian community in the United States. Although Ambassador Fava recommended caution, Italian newspapers in the United States published fiery articles full of indignation. Hence Fava informed the Foreign Ministry in Rome that he had sent a telegram to the royal consul general in New Orleans, urging him to encourage the Italian colony there to stay calm and, as he put it, "to observe legality strictly." 41

Nevertheless, Ambassador Fava was very worried about the anger and frustration of the Italian community. In fact, on March 18, 1891, he sent a telegram to Minister Rudinì, asking him to prohibit Italian consuls from giving out any information regarding the facts of New Orleans. In addition, in a confidential report sent the following day, Fava expressed his own anxieties regarding inflammatory articles about the New Orleans events, published especially in New York, and telegrams sent to the Italian embassy, requesting protection for Italian citizens in the United States. Fava knew that Italians generally did not enjoy a good reputation in the United States, and that there was a risk that lynchings and Italian reaction to them might spark further acts of violence against Italians. It was therefore imperative, Fava maintained, in order to avoid very serious repercussions and in the interest of a quick resolution of the tensions now existing between the two countries, that Italian communities behave prudently. ${ }^{42}$

\footnotetext{
${ }^{41}$ ASDMAE, Serie Politica “P” (1891-1916). From the Italian Embassy at Washington to MAE, 16 March 1891.

${ }^{42}$ ASDMAE, Serie Politica "P” (1891-1916). From the Italian Embassy at Washington to MAE, 19 March 1891.
} 
Consul Riva in New York had also urged prudence in a proclamation he addressed to the Italian community in New York in which he assured its members that Rome would protect its subjects. At the same time, he warned them not to inflame the situation but to behave with prudence and moderation. ${ }^{43}$ Moderation, however, was not what Consul Corte in New Orleans practiced. Corte blamed the authorities of the State of Louisiana for the bloody event. He defended the Italian community of New Orleans, calling it industrious, frugal, and tranquil. ${ }^{44} \mathrm{He}$ did acknowledge that within it were delinquents who had avoided Italian prisons, but they had long been naturalized as American citizens and were deeply enmeshed in the often corrupt politics of Louisiana and New Orleans, protected by politicians and often obtaining important political appointments. ${ }^{45}$

Corte suspected that the assassination of Chief Hennessy, himself a player in the corrupt politics of the city, should be seen as part of a political struggle for control between two political factions: the Provenzanos, supported by Hennessy, and their enemies, the Matrangas. Corte suggested that, to cover up such political corruption, city officials targeted the Italian community, arresting hundreds of its members and harassing and even robbing many of them. It was

\footnotetext{
43،"Il Proclama del Console Generale d’Italia, cav. G.P. Riva, sulla luttuosa tragedia di New Orleans,” in L'Eco d'Italia," 17 March 1891.

44 "Rivelazioni del Console Italiano di New Orleans. Le autorità americane dello stato sono colpevoli,” in L'Eco d'Italia, New York, 19 March 1891.

${ }^{45}$ Ibid.
} 
the same city officials who, according to Corte, bribed some of the jurors and declared the accused guilty long before the trial was held. ${ }^{46}$

Moreover, Corte claimed that the trial was seen as an opportunity to free the city of New Orleans of Italian delinquents and that some jurors had been bribed for this reason. Other jurors, according to Corte, seemed interested in finding the accused guilty, hoping to gain some economic advantage, while others wished to vindicate the mayor's claim that the Italians were guilty. The jury, however, acquitted the Italians, and the authorities could not protect them from a lynch mob. According to Corte, they could have been saved had they been transferred somewhere else. ${ }^{47}$

According to historian Richard Gambino, no evidence could be found of the alleged bribery of the jury that tried the eleven Italians accused of the murder of Hennessy. An examination of available documents failed to connect any of the persons killed with that charge. Nor was there any direct evidence connecting those eleven individuals with the mafia or any other similar association in the city of New Orleans. ${ }^{48}$ Gambino maintains that the New Orleans political and commercial power saw the murder of Chief of Police Hennessy as an opportunity to destroy the rising economic power and social threat of the Italian community. Persecuting the entire Italian community would put wealthy Italians in their place

\footnotetext{
${ }^{46}$ Ibid.

${ }^{47}$ Ibid.

${ }^{48}$ Gambino, Vendetta, 191. Gambino based this analysis on the report by Federal District Attorney William Grant to U.S. Attorney General William H.H. Miller, 186-193.
} 
and "responsible" native-born citizens could regain their influence and profitable commerce. $^{49}$

The American press blamed the lynchings on the criminal activities of the mafia in New Orleans. On the other hand, Italian newspapers, basing their stories largely on Corte's reports, denounced the horrors of the massacre and the lack of justice in the way the New Orleans authorities had handled the case. In particular, L'Eco d'Italia of New York charged that the Italians had been victims of racism, portraying them as sheep killed by wolves. It called on Italians throughout the country to react vigorously and urged them to seek revenge. ${ }^{50}$ The same article emphasized the need for the Italians to be united and urged other newspapers such as the Progresso Italo-Americano and the Colombo to join in a mass demonstration against the events in New Orleans. ${ }^{51}$

The demonstration did not take place, but the lynching at New Orleans inflamed passions and left deep suspicion among Italians and Americans alike. Italian authorities continued to receive reports of abuse and violence against their nationals. Some of the reported acts of violence were false but, whether true or not, they were indicative of the climate of tension, fear, suspicion, ethnic hatred, and exasperation fueled by the New Orleans lynching.

One example of a fictitious lynching was reported on 17 June 1892 by the Seattle Press Times. It wrote that four Italians had been lynched on June 13 and

\footnotetext{
${ }^{49}$ Ibid., 48.

50 "Rivelazioni del Console Italiano di New Orleans. Le autorità americane dello stato sono colpevoli,” in L'Eco d' Italia, New York, 19 March 1891.

${ }^{51}$ Ibid.
} 
that it was likely that four more would be executed for reportedly having killed their boss, a Norwegian named Nelson, at the site of the building of the Monte Cristo Railroad in Skagit County. The newspaper ascribed the episode to the discrimination to which Italian workers were subjected because of an existing ethnic hierarchy in the work place. It reported that Italians were forced to accept the heaviest jobs, such as digging all day, while "white" workers were allowed to work the stone, and that the 175 Italians were made to live separately from the fifty "white" workers. The article also claimed that the Italians were stereotyped as "bloodthirsty individuals" even though they were armed only with knives while whites carried guns. ${ }^{52}$

On 18 June 1892, news of the lynching prompted La Tribuna of Rome to urge the Italian government to lodge a formal protest with the U.S. government. Ambassador Fava, on his own initiative, had already unofficially done so with a request that President Benjamin Harrison urge the governor of Washington State to investigate the lynching. ${ }^{53}$

Two days later, on June 20, the Seattle Press Times announced that the story of the hanging was fake and that it had been concocted by individuals who wished to discredit the Italians and to foment racial antagonism. ${ }^{54}$ Ambassador

\footnotetext{
52 “A Murder Arranged. Four Italians Assassins Hanged in the Woods,” in The Seattle Press Times, 17 June 1892.

${ }^{53}$ Ibid. “The Story is True. Four Italians Lynched at Monte Cristo,” 18 June 1892.

${ }^{54}$ Ibid. “No Men Were Lynched,” 20 June 1892.
} 
Fava confirmed the newspaper's report, ${ }^{55}$ as did the Italian consul in San Francisco who had initially doubted the veracity of the newspaper report. ${ }^{56}$

One year later, an Italian individual was lynched. Daniele Arata was a naturalized American citizen originally from the Italian region of Liguria; he owned a saloon and the hotel Italia in Denver, Colorado. In1893, Arata, a notorious alcoholic, got drunk and killed a customer for no apparent reason. Arrested, he was taken from the prison by an enraged mob and was hanged from a tree, his body mutilated in what the local Italian newspaper, Roma, described as "a macabre dance and a cayman feast.." ${ }^{57}$ The newspaper suggested that the authorities had not been able to stop the mob while another local paper, the Rocky Mountain News, denounced the inefficiency and connivance of the police and other public officials, claiming that they had known about the town's strong resentment against the Italian and should have taken appropriate measures in order to avoid the tragedy. ${ }^{58}$ In a report to Ambassador Fava, the Italian Consul at Denver, Bruno Grimaldi, expressed his great anxiety for the safety of the Italian community, urging its members not to go en masse to the cemetery but to limit visits to the victim's closest relatives. ${ }^{59}$

\footnotetext{
${ }^{55}$ ASDMAE, Serie Politica “P” (1891-1916), pacco 357, From the Italian Embassy to MAE, 20 June 1892.

${ }^{56}$ Ibid., From the Consul General at San Francisco to the Italian Embassy at Washington, 24 June and 5 July, 1892.

57 “L’assassinio di Wewatta Street,” in Rome, 29 July 1893.

58 “Arata Lynched,” in The Rocky Mountain News, 27 July 1893.

${ }^{59}$ ASDMAE, Serie Politica “P” (1891-1916), pacco 591, pos. 430. From the Consulate General at Denver to MAE, 31 July 1893.
} 
Writing to the Foreign Ministry in Rome, Ambassador Fava reported that he had taken no direct action in the Arata matter because the victim was a naturalized American citizen and was no longer under the protection of the Italian government. He attributed the episode to an economic downturn that had provoked competition among different ethnic groups. He maintained that Daniele Arata probably would not have met such a tragic end had the closing of the silver mines and other important factories not caused such high unemployment and hardships throughout the community. These conditions may also have been the reason that the four individuals arrested for the crime were never tried. ${ }^{60}$

Two years later, in 1895, three more Italians were lynched in Walsenburg, Colorado. On 11 March 1895, the dead body of a local beer producer, Aber J. Hixon, was found. An Italian named Lorenzo Andinino confessed to the murder and was taken to the local jail. While a police investigation was conducted, nine Italian miners were also arrested. Four of them were released when it became apparent that they had not been involved in the crime. The other five--Lorenzo Andinino, Pietro Giacobini, Stanislao Vittone, Antonio Gobbetto, and Francesco Ronchietto-- were taken to the prison of Walsenburg, escorted by two deputy sheriffs. While en route to the prison, men on horseback halted the group; they shot and killed Vittone and wounded Ronchietto, who was taken to prison, together with Andinino. During the night, intruders killed both Ronchietto and

${ }^{60}$ ASDMAE, Ibid., From the Italian Embassy at Washington to MAE, 3 August 1893. 
Andinino. The other Italians, Giacobini and Gobbetto, had managed to escape during the attack, but were later found and re-arrested. ${ }^{61}$

Italian Ambassador Fava sent a request immediately to Secretary of State Richard Olney (1895-1897), urging him to prompt the Governor of Colorado, Albert W. McIntire, to ensure the protection and safety of Italian citizens residing in Walsenburg. He cautioned Rome, however, not to expect satisfactory results, given the serious difficulties Washington encountered whenever it attempted to force states to comply with foreign treaties. Fava pointed to the recent New Orleans lynching where, in spite of Washington's good intentions, no legal action had been taken by local and state authorities seemingly determined to exert the autonomy granted them by the U.S. Constitution. ${ }^{62}$

The Italian newspaper La Voce del Popolo, of San Francisco, also addressed this feature of the U.S. Constitution concerning the relationship between federal and states governments in diplomatic disputes such as the one provoked by the New Orleans lynching. According to the newspaper, "the President of the American Union represented the whole nation with foreign countries; however, he did not have any jurisdiction over the single States that together made such Union. Therefore, while he had the right to request that any foreign country be accountable for offense against American citizens, he cannot demand that same accountability by the single States of the Union which are

\footnotetext{
${ }^{61}$ ASDMAE, Serie Politica "P” (1891-1916), pacco 605, pos. 517. From Italian Embassy at Washington to MAE, 14 March 1895.

${ }^{62}$ ASDMAE, Ibid. pacco 605, pos. 517. From Italian Embassy at Washington to MAE, 14 March 1895. The correspondence between the Italian embassy and the U.S. State Department is also contained in FRUS, 1895, 938-956.
} 
autonomous." ${ }^{63}$ The article argued that this feature of the Constitution nullified de facto one important clause contained in foreign treaties negotiated between the United States and other countries, the "reciprocity clause." The newspaper defined as "simply grotesque" the condition of the president of a nation who "represented the whole, but not the single parts," thus making his representation no more than an illusion. Moreover, according to La Voce del Popolo, it was not likely that the lynchers would be brought to justice because if the assassins were arrested and tried in a court of law, no jury in Colorado would be so impartial as to hand down a guilty verdict. ${ }^{64}$

The same article also addressed the issue of indemnity for the families of the lynching victims in Colorado, indicating that Washington had stated, although unofficially, that the indemnity granted to the families of the New Orleans victims did not constitute a precedent. That indemnity, granted by President Benjamin Harrison was presented as an act of courtesy toward Italy and an act of charitable compassion for the survivors of the massacred victims. Moreover, in granting the indemnity, the federal government had not admitted any responsibility for the lynching. Therefore, according to the article, the granting of indemnity in New Orleans could not be interpreted as an acquired right for families of lynched individuals; on the contrary, the U.S. government at several junctures had declined any responsibility. Finally, the article urged the government of Italy to put pressure on the U.S. government to comply with international treaties and asked whether the Italian government of Francesco

\footnotetext{
63 “Il linciaggio di Walsenburg,” in La Voce del Popolo, San Francisco, 18 March 1895.

${ }^{64}$ Ibid.
} 
Crispi, who always claimed to be the defender of national dignity abroad, would accept once more an ambiguous solution that would weaken U.S.-Italian relations. ${ }^{65}$

One urgent question that arose from the Walsenburg incident was the issue of citizenship: whether two of the victims, Ronchetto and Vittone, who had submitted applications to become naturalized American citizens, were still under the protection of the Italian government. According to Ambassador Fava, submitting an application for citizenship did not make one a citizen, as the American authorities usually claimed in cases of lynchings. Fava insisted that the Italian government continue to view such individuals as loyal subjects of the king of Italy for five years after submitting a naturalization application. Until citizenship was fully completed, Fava maintained, Italian citizens would not lose their Italianness. $^{66}$

Even American authorities suspected that, at Walsenburg, the two deputy sheriffs and prison guard had either cooperated in or at least failed to obstruct the lynching of the Italians. In fact, the state government had promised to anyone who would contribute to finding the guilty assassins a sum of $\$ 1,000-$ the highest amount allowed by the Fundamental Statute of the State of Colorado. According to Consul Giuseppe Cuneo, the high reward was clearly a sign that local authorities were involved with the murder of the Italians. After the murders, Consul Cuneo interviewed under oath one of the survivors, Giacobini, after he

\footnotetext{
${ }^{65}$ Ibid.

${ }^{66}$ ASDMAE, Serie Politica “P” (1891-1916), pacco 605, pos. 517. From Italian Embassy at Washington to MAE, 16 March 1895.
} 
was found exhausted but alive. Giacobini testified that only one man had attacked the group at the Bear Bridge Creek and that the two deputy sheriffs had done nothing to stop him. ${ }^{67}$ Hence, the governor's zeal in promising an award could be interpreted as acknowledgement of connivance on the part of local authorities.

Ambassador Fava had similar suspicions. In fact, he emphasized the culpability of the local authorities for not having stopped the Walsenburg lynching in his correspondence not only with the Italian Foreign Ministry, but also with the State Department and, through the latter, with the Governor of Colorado, Albert McIntire. Fava informed the Ministry that he had started the necessary paperwork to request an indemnity for the victims' families. ${ }^{68}$

The Walsenburg Italian community really appreciated the efforts of Colorado Governor McIntire to try to find those who had committed the crime. In fact, the Italians who lived in Walsenburg offered the governor a gift as a sign of their gratitude. ${ }^{69}$ One year after the episode, however, the guilty party still had not been found, and those who had committed the lynching remained unknown. On 12 February 1896, the grand jury appointed to investigate the Walsenburg incident released its findings and concluded that legal proceedings would be terminated because of lack of sufficient evidence. ${ }^{70}$ Disappointed by the grand jury's verdict, Fava contacted Secretary of State Richard Olney, asking him to

\footnotetext{
${ }^{67}$ Ibid., From the Italian Consulate at Denver to the Italian Embassy at Washington, 21 March 1895.

${ }^{68}$ Ibid., From the Italian Embassy at Washington to MAE, 27 March 1895.

${ }^{69}$ Ibid., From the Italian Consulate at Denver to Italian Embassy at Washington, 12 April 1895.

${ }^{70}$ Ibid., From Italian Embassy at Washington to MAE, 19 February 1896.
} 
pressure the U.S. Congress to grant an indemnity to the victims' families. A few months later, Congress voted in favor of compensation of $\$ 10,000$ to be divided equally among the families of the three killed and two injured Italians. ${ }^{71}$

What might have led to the lynching of Italians at Walsenburg? A study by Conrad Woodall interprets this case of violence as an isolated episode of simple frontier justice. Woodall denies any explanation based on mere xenophobia or community self-defense from foreign intruders competing for jobs. Indeed, Woodall argues that what happened to the Italians could have happened to any other ethnic group in the town. The Italian community in Walsenburg was very small, only 163 according to the census of 1900 , too small to cause fear. There was, he concludes, a communication problem in language and culture, but Woodall rejects the theory that local authorities connived to obstruct justice. He blames the shortcomings on the local authorities' inefficiency, incompetence, and lack of sensitivity rather than connivance. Woodall also dismisses the notion that political or union issues played a role in the killing of the Italians. That they were foreigners was the only motive. It did not matter to which ethnic group they belonged; being estranged was the principal motive for the massacre. ${ }^{72}$ Indeed, Consul Cuneo's reports suggest that ethnic hatred, job competition, or union activities were not factors in the incident.

\footnotetext{
${ }^{71}$ FRUS, 54th Cong., 2nd sess., 1896. Indemnity to Heirs of Italian Subjects Killed at Walsenburg. Colo., Department of State, Washington, 12 June 1896, Doc. 129, 422.

72 Conrad L. Woodall, “The Italian Massacre at Walsenburg, Colorado, 1895” (paper presented at the annual meeting of the American Italian Historical Association, Chicago, IL, November 11-13, 1987). See also Dominic Candeloro, Fred L. Garbaphe and Paolo A. Giordano, eds., Italian Ethnics: Their Languages, Literature and Lives, Proceedings of the $20^{\text {th }}$ Annual Conference of the American Italian Historical Association, Chicago, Illinois, November 11-13, 1987, Staten Island, NY: American Italian Association, 1990, 297-317.
} 
The next lynching of an Italian citizen occurred in Hahnville, Louisiana, one year later. On 5 August 1896, an American named Gueynard was killed and a friend of his injured not far from New Orleans. The alleged murderer, an Italian named Lorenzo Salardino, was arrested. Immediately The Daily Picayune announced rumors of a lynching. ${ }^{73}$ The following day, an article in the same newspaper described the alleged killer as pursuing "innate brutality," fueling growing popular anger. In fact, the following day, on August 8, a mob invaded the Hahnville prison, and took the alleged murderer as well as two other imprisoned Italians, Salvatore Arena and Giuseppe Venturella. The two Italians were accused of a murder that subsequent events showed they had not committed. The mob hanged all three individuals. The next day, the Daily Picayune described the event as a protest against "mafia methods," but said nothing of the mob or of the failure of the authorities to protect individuals waiting to be tried in a court of law. ${ }^{74}$

With this case, Italian officials in the United States found themselves enmeshed in all sorts of problems. They found Italian residents in Hahnville living in fear for their lives and thus unwilling to testify, making their collection of information more difficult. The consular agent at New Orleans, Carlo Papini, apologized to Ambassador Fava for the lateness of his report, but informed him that many of the Italians who knew the lynched individuals and who could have

\footnotetext{
73 “Assassinated in St. Charles,” in The Daily Picayune, 6 August 1896.

${ }^{74}$ Ibid., “Trio Lynched in St. Charles,” 9 August 1896.
} 
provided information did not want to talk, most of them out of fear of retribution, but some for not receiving proper compensation. ${ }^{75}$

The incident sparked an intensive exchange of correspondence between the Italian embassy and the U.S. State Department about existing laws concerning the treatment of foreigners residing in the United States. Following the Hahnville incident, with the number of lynchings of Italians rising, Ambassador Fava reported to the Italian Foreign Ministry in Rome the procedure to be followed on the part of the Italian government as well as the provisions of the U.S. Constitution. Fava informed the Ministry that usually state authorities were required to report the simple facts to the federal government and then to ascertain whether the victims had obtained U.S. citizenship. If the individuals had already become naturalized American citizens, then the U.S. government did not recognize the authority of any foreign government for a crime committed against an American citizen. If the lynched individual had kept his original nationality, then the federal government urged the state authorities to comply with existing treaties concerning protection of foreign citizens from friendly countries and to take all necessary measures to find the guilty parties and bring them to justice. Moreover, the State Department would start all necessary paperwork concerning the granting of indemnity to the victims' families and forward it to the U.S. Congress. However, such a provision could not be finalized by the State

\footnotetext{
${ }^{75}$ ASDMAE, Serie Politica “P” (1891-1916), pacco 623, pos. 629. From the Italian Consulate at New Orleans to the Italian Embassy at Washington, 14 August 1896.
} 
Department until the state authorities had confirmed the nationality of the victims. ${ }^{76}$

The most problematic issue remained the relationship between the federal and state governments. Until the U.S. Constitution could be modified so that foreign citizens could be placed under federal protection and responsibility, Ambassador Fava maintained, the federal government could do nothing but make suggestions to state authorities without really being able to intervene directly in conducting inquiries and bringing lynchers to justice. ${ }^{77}$ Ultimately, it seemed that the only role of the federal government would be the granting of an indemnity, as voted by the U.S. Congress, to the victims' families.

In the Hahnville case, the Louisiana Governor, Murphy J. Foster, had delayed sending the report about the lynching, thus slowing any proceedings by Washington. When the report finally reached the State Department, it was forwarded to Ambassador Fava with the acknowledgement that the State Department found the report "very unsatisfactory." ${ }^{178}$ The report contained the grand jury's vote against pursuing the case because there was not enough evidence and it was not possible to proceed against unknown persons. The report also concluded that the lynching was not specifically aimed against

\footnotetext{
${ }^{76}$ U.S. Congress. Senate. Correspondence Regarding the Lynching of Certain Italian Subjects. 56th Cong., 1st sess., 1897. S. Doc. 104, Washington, GPO, 1897.

${ }^{77}$ ASDMAE, Serie Politica “P” (1891-1916), pacco 623, pos.629. From the Italian Embassy at Washington to MAE, 22 August 1896.

${ }^{78}$ FRUS, 54th Cong., 2nd sess.,1896, Mr. Adee to Baron Fava, Washington August 28, 1896, 403.
} 
Italians, giving as evidence the fact that other Italians held in the jail were not lynched. ${ }^{79}$

In the more complete report Fava compiled for Rome, which was based on the magistrate's investigation and on the coroner's report, he highlighted four points: (1) that the lynching had been carried out by unknown individuals; (2) that the bloody affair had resulted from indignation concerning the assassination of Gueymard; (3) that the community deemed Salardino guilty along with the other two Italians, and (4) that the murder was a further expression of the violence that so shamed American civilization. ${ }^{80}$

Although Secretary of State Richard Olney sent a special envoy to Louisiana four months after the event, the guilt of the three victims had not yet been ascertained. Ambassador Fava in a report expressed his disappointment concerning the mission of the special agent. Fava complained that everyone seemed to agree the three Italians were guilty even though, according to U.S. law, any person is deemed innocent until proven guilty in a court of law. ${ }^{81}$ Fava charged that the envoy, instead of uncovering the truth, had covered up the shortcomings and negligence of the local authorities who, as the special envoy acknowledged, knew that there were people speaking openly about lynching the accused, but had not taken any measures to prevent it. ${ }^{82}$

\footnotetext{
${ }^{79}$ Ibid.

${ }^{80}$ ASDMAE, Serie Politica “P” (1891-1916), pacco 623, pos. 629. From Italian Embassy at Washington to MAE, 28 August 1896.

${ }^{81}$ FRUS, 54th Cong., 2nd sess., 1896. Special Agent Report in Mr. Olney to Baron Fava, Washington, November 27, 1896, 407-412.

${ }^{82}$ FRUS, 54th Cong., 2nd sess., 1896, Fava to Olney, December 31, 1896, 412-418
} 
Fava also criticized the behavior of the sheriff who had taken the alleged assassin, Salardino, to the woods and then had decided to take him back to the Hahnville jail. A few hours before the murder, the sheriff withdrew the guards from the jail and he himself left, thus abandoning the Italians to certain death. It was not possible, Ambassador Fava maintained, to make it any easier for the lynchers to carry out their plan. ${ }^{83} \mathrm{~A}$ confidential report by the Italian consul Carlo Magenta of New Orleans to the Italian embassy at Washington revealed horrifying details of how the three Italians had been tortured as they were being hanged in the woods by the savage mob even though the three victims proclaimed their innocence. ${ }^{84}$

Fava also denounced the way the investigation of the lynching had been conducted. It is true that the grand jury had assembled, but because no detective had been assigned to the investigation and no witnesses had been were called by the district attorney, no one appeared to testify, and the grand jury adjourned. According to Fava, even the special envoy sent by Washington had been inclined to cover up the shortcomings of the civil and judiciary authorities in Louisiana rather than uncover any evidence. ${ }^{85}$

Ambassador Fava was also indignant that Secretary of State Olney had chosen to treat the three Italians as if they were already naturalized American citizens, thus making it difficult for the Italian government to protect their rights.

\footnotetext{
${ }^{83}$ Ibid.

${ }^{84}$ ASDMAE, Ibid. From the Italian Consulate at New Orleans to the Italian Embassy at Washington, 30 March 1898.

${ }^{85}$ Ibid.
} 
Washington claimed that they were outside Italy's jurisdiction because they had applied for citizenship, had received part of the documentation, could legally vote in the State of Louisiana, worked and resided in Louisiana, did not show any intention of returning to Italy, and did not contribute to the Italian economy. Furthermore, having left Italy, they had avoided military service and voting obligations. Thus, according to both the U.S. Constitution and Louisiana law as interpreted by the Supreme Court, they were now American citizens. Fava's position was that the federal government, not the state, could originate the process of naturalization. He also maintained that a simple "declaration of intention" to become a citizen could not automatically make an individual a naturalized U.S. citizen. ${ }^{86}$

On 8 July 1897, the Hahnville case ended when the U.S. Senate approved the standard amount of $\$ 2,000$ to the families of each of the three victims ${ }^{87} \mathrm{~A}$ month and a half after the "blood price" had been paid, an article published in the New York Herald announced that a black man from Hahnville, Louisiana, had confessed to murdering Gueymard, the crime for which Salardino, Arena, and Venturella had lost their lives. The news was confirmed by Italian Consul Papini in New Orleans. The black man, nicknamed "Creole," had been accused of and indicted on several counts of homicide, but not that of Gueymard. The authorities

\footnotetext{
${ }^{86}$ FRUS, 54th Cong., 2nd sess., 1896, Baron Fava to Mr. Olney, Washington, December 31, 1896, 413418; copy also in ASDMAE, Serie Politica “P” (1891-1916), pacco 623, pos. 629.

${ }^{87}$ FRUS, 55th Cong., 1st sess., Mr. Adee to Baron Fava, Washington, 30 July 1897, 353-354.
} 
did not release Creole's confession, and he was found guilty of other crimes and hanged in January $1898 .^{88}$

The Hahnville incident was the last attempt by the U.S. government to argue that a foreign-born individual who had submitted all necessary paperwork to become naturalized could be considered a citizen. With a lynching in Tallulah, Louisiana, the last one to occur in the United States in the late 1890s, the U.S. government finally acknowledged that a foreign-born individual could not be considered a U.S. citizen until all necessary paperwork had been finalized and citizenship had been fully granted. ${ }^{89}$

The lynching at Tallulah, Louisiana, in 1899 involved five Italians accused of murder. The incident began with a sheep belonging to an Italian named Francesco Difatta. The sheep often trespassed onto the property of a neighbor, Dr. J. Ford Hodges, a medical doctor and coroner. On 20 July 1899, the two individuals had an argument about the sheep. Francesco's brother Giuseppe rushed out of the house in his brother's defense and shot and wounded the doctor. Several people appeared on the scene, and the two Difatta brothers went back into the house where there was a third brother, Carlo. Two other Italian men, Rosario Fiducia and Giovanni Cerami, were also in the house. The sheriff arrived and arrested Fiducia, Cerami, and Francesco Difatta, but not the latter's brothers, Carlo and Giuseppe, who were in hiding. The three men did not

\footnotetext{
${ }^{88}$ ASDMAE, Ibid. From the Italian Embassy at Washington to MAE, 2 September 1897.

${ }^{89}$ FRUS, 1898, 57th Congr., 2nd sess., No.1, 353, 354.
} 
resist arrest, even though they were armed "as anyone else in the area." 90 During the night, a savage mob stormed the prison, took the three prisoners out of jail, and hanged them from the trees in the prison courtyard. The mob started looking for the other two Difatta brothers, found them, and hanged them near the slaughterhouse. The five men were all Sicilian, four from Cefalù, and one from Cerami, in the province of Messina. They all worked in fruit and vegetables commerce and were doing quite well. ${ }^{91}$

Once again, the grand jury seemed to be influenced by the usual stereotypes about Italians. It declared that the five men had plotted to murder the doctor and that, "after a diligent inquiry," the identity of the people who had committed the lynching could not be ascertained. Such a statement, however, was not very credible in a small town such as Tallulah with barely four hundred inhabitants, all of whom knew one another, as the newspaper L'Italo-Americano pointed out. ${ }^{92}$ This was the repetition of a now well-established pattern of grand juries failing to indict anyone in a lynching investigation. In fact, as L'ItaloAmericano reminded its readers in 1899 , in no lynching case had the guilty party ever been arrested and punished. ${ }^{93}$

The next day, the same newspaper called Louisiana the classic land of lynchings "within the superior American civilization." It noted that the minority that took part in a lynching always acted with the connivance of the silent

\footnotetext{
90 "Il linciaggio di cinque Italiani a Talullah, La.,” in L'Italo-Americano, 22 July 1899.

${ }^{91}$ Ibid.

${ }^{92}$ Ibid.

${ }^{93}$ Ibid.
} 
majority. Grand juries, by failing to indict lynchers, were the symbol of the silent majority's granting license to the lynching minorities to continue to carry out their barbarous acts. ${ }^{94}$

In response to the Tallulah case, the Italian chargé d'affairs in Washington, Count Vinci, contacted Secretary of State John Hay who, to his credit, showed concern and offered to help to solve the case as quickly as possible. ${ }^{95}$ The Italian embassy also charged the Italian Consul at New Orleans, Natale Piazza, with the task of conducting an inquiry, and the embassy appealed to the editor of the Italo-Americano in New Orleans, prompting him to cooperate fully with the consular agent. The main goal of Ambassador Fava was to ascertain whether the five men lynched still held Italian citizenship or whether they had applied to be naturalized American citizens. It proved to be very difficult to conduct an inquiry because it was not possible to obtain affidavits at the site of the crime as Italians could no longer be found there, nor was it advisable, consul Piazza maintained, for Italians to trust any Americans. ${ }^{96}$

Piazza, however, managed to put together a thorough report concerning the facts, the role of Dr. Hodges in the confrontation, the reluctance of witnesses to testify, and the pervasive anti-Italian climate in Tallulah. Piazza was skeptical about the role of the sheriff, who had made no attempt to stop the violence and refused to share any names of witnesses who might facilitate the investigation.

\footnotetext{
94، Il linciaggio di cinque Italiani a Tallulah,” L’Italo-Americano, 23 July 1899.

${ }^{95}$ The correspondence between the Italian ambassador and Secretary of State John Hay is contained in FRUS 1899, 440-446 and 715-736.

${ }^{96}$ ASDMAE, Serie Politica "P” (1891-1916), pacco 656. From the Italian Consulate at New Orleans to MAE, 26 July 1899.
} 
The lynching, according to Piazza, had been carried out by "a mob of assassins who savored the pleasure of a vendetta and who enjoyed the open approval of the savage townspeople of Tallulah." ${ }^{97}$ The Italians were killed, he concluded, because of racial hatred, economic competition, jealousy, and opposition to the right to vote. He hoped that Louisiana Governor Foster might exercise his power and put pressure on the local authorities to bring the guilty parties to justice. ${ }^{98}$ This, of course, was not likely to happen. As the Italo-Americano had charged, very little hope existed that the American system of justice could be trusted in any case involving the lynching of foreigners. The administration of justice, the newspaper maintained, was in the hands of the lynchers' friends, who were perfectly secure in their impunity. ${ }^{99}$

Although no individuals were punished for the lynching at Tallulah, the controversy ended with payment of the "blood price" to the families of two victims. In fact, the investigation by the agent of the Department of Justice into the Tallulah lynching revealed that two of the lynched men had not been naturalized. Consequently, by the act of March 3, 1901, Congress appropriated the sum of $\$ 4,000$ to be paid "out of humane consideration, without reference to the liability thereof, to the Italian Government as full indemnity to the heirs of

\footnotetext{
${ }^{97}$ ASDMAE, Ibid. From consular agent Piazza to the regent of the Italian Consulate at New Orleans, 29 July 1899.

${ }^{98}$ ASDMAE, Ibid. From consular agent Piazza to the regent of the Italian Consulate at New Orleans, 29 July 1899.

99 “Un’asserzione coraggiosa sul linciaggio di Tallulah,,” in L'Italo-Americano, 27 July 1899.
} 
Joseph (Giuseppe) Difatta and John (Giovanni) Cirano, Italian citizens lynched at Tallulah, on July $20,1899 . " 100$

In his assessment of the crime, Count Vinci, in a letter to Rome, concluded that "No lynching had been more unjust and atrocious than the vulgar murder that occurred at Tallulah to get rid of foreign-born individuals in the town." ${ }^{101}$ In fact, in Italy, the Tallulah massacre created such an echo that a song was composed by an itinerant entertainer who, while dancing in the streets of Italy, sang the following lyrics:

\author{
I sing for those lynched ones \\ How industrious and honest they were \\ Because they were Italian \\ There was no pity for them \\ Oh youth of Italy \\ The flag was obscured \\ Of the vile mob \\ Have revenge. ${ }^{102}$
}

The Tallulah event was the last lynching of the 1890s, but the phenomenon continued into the new century. Strong anti-Italian sentiment persisted in the United States in the early 1900s. Hence, Italian diplomats and politicians continued to deal with the problem of protection of Italian nationals who worked in the United States. In general, in spite of several episodes of lynching, they adopted an attitude of prudence and moderation--except for the New Orleans case, which provoked a serious diplomatic incident and nationalistic

\footnotetext{
${ }^{100}$ FRUS 56th Cong., 2nd sess., 1900, 715-731.

${ }^{101}$ ASDMAE, Ibid., From the Italian Embassy at Washington to MAE, 6 August 1899.

${ }^{102}$ The song is published in Emilio Franzina, Dall'Arcadia in America. Attività letteraria ed emigrazione transoceanica in Italia 1850-1940 (Turin: Fondazione Giovanni Agnelli, 1996), 101.
} 
fervor in the Italian Parliament, culminating in Rome's recall of its ambassador, Baron Fava. This cautious attitude indicates that Italy depended on emigration as a safety valve for its domestic social peace as well as its economic growth. 


\section{CHAPTER V}

\section{MORE LYNCHINGS, VIOLENCE AND HARASSMENT}

\section{IN THE EARLY 1900s}

Italian diplomats found themselves dealing with an ongoing series of provocations that challenged their commitment to caution and pragmatism in dealing with the United States in matters of immigration. Strong anti-foreign feelings characterized American society in the 1890s and in the early 1900s. Americans looked at southeastern Europeans, in particular, with a growing sense of dislike, mistrust, and hostility. Dislike swelled into a widespread sense of menace that often turned into violence. Southern and eastern Europeans became a significant factor in the growth and strengthening of nativism in America. The development of general anti-foreign feelings led most American nativists to look at different southeastern European groups as insidious representatives of the whole foreign menace. In the early 1900s, more exclusively than had previous immigrant groups, the "new immigrants" swarmed into the slums, factories, mines, and agricultural areas of the South. In the eyes of Americans who felt threatened by these newcomers, the new immigrants symbolized all social and economic evils with which nativists generally identified immigrants. $^{1}$

However, the new immigrants were not a single identifiable group.

Although in general all newcomers were considered uncivilized, each group was stereotyped differently. For instance, the Slavs were seen as dangerous, furious

\footnotetext{
1 John Higham, Strangers in the Land: Patterns of American Nativism, 1860-1925 (1955; repr., New Brunswick: Rutgers University Press, 1998), 87-88.
} 
"Huns"; the Jews were unscrupulous, greedy, stingy Shylocks; and the Italians were all dangerous subversives, hot-heads, violent members of the Mafia always ready to reveal their knives or their hidden guns. It was believed that a general disposition to assassinate was embedded in the character of this violent race; these people were always impulsive, inexorable, and prone to murder. The stereotype influenced all major outbursts of anti-Italian sentiment in the 1890s and the early 1900 s. $^{2}$

Again and again, lynching parties struck at Italians charged with murder or suspected of having murdered a native-born American citizen. Such was the case of a lynching that occurred in Erwin, Mississippi, on July 10, 1901, at midnight. Three Italians--Giovanni Serio, his son Vincenzo, and Salvatore Liberto, all Italian citizens--were shot by an armed mob while they were sleeping outdoors on the porch of the house of a friend, Francesco Cascio. Having been shot several times, Vincenzo died within minutes. Giovanni, too, was badly injured, his left hand horribly mutilated with some fingers missing, and he died early the next morning. He called for help several times during the night. Salvatore Liberto miraculously survived the attack, but his legs were badly injured. $^{3}$

The delegate to the Italian consul in New Orleans, N.L. Tirelli, reconstructed the sequence of events that led to the shooting in a report to consular agent Natale Piazza. The report was based on the testimony of

\footnotetext{
${ }^{2}$ Ibid., 89-91.

${ }^{3}$ ASDMAE. Serie Politica “P,” (1891-1916), pacco 680, pos. 856; ASDMAE, Italian Representative at Washington (1901-1909), pacco 147, pos. 3225, July 24, 1901. From Italian Consulate at New Orleans to Italian Embassy at Washington, 24 July 1901.
} 
Salvatore Liberto, who had survived the attack; his brother, Rosario Liberto; Francesco Cascio, owner of the house; his nephew, Salvatore Cascio; and other Italians in the community such as Vincenzo Giglio and Salvatore Butero. ${ }^{4}$

According to Tirelli, the Serios, who operated a fruit and vegetable business in Glen Allen, about six miles from Erwin, owned property adjacent to "Greenfield" plantation. The Serios' horse frequently wandered onto the neighbor's property, whereupon the overseer, G.B. Allen, each time would refuse to return it until the Serios paid one dollar for damages caused by the horse. Because Allen threatened Vincenzo Serio with a gun during another trespassing incident, Vincenzo armed himself the next time he went to retrieve the peripatetic horse. No shooting occurred, but that same night, G. B. Allen and a group of armed men went to the Serios' home, apparently intending to kill them. The Serios escaped and found refuge in the home of their friend, Francesco Cascio, who invited them to remain at his home in Erwin. On the night of July 10, Francesco and Salvatore Cascio were sleeping in the house while, as we have seen, the victims Giovanni and Vincenzo Serio and Salvatore Liberto were sleeping outdoors on the porch. ${ }^{5}$

While conducting his investigation, Tirelli learned that at Glen Allen, no secret was made of the preparations for the lynching of the Serrios, father and son. In fact, Vincenzo Giglio and Giuseppe Butero, two Italians who got wind of it, attempted to telephone the Serios and warn them of the imminent danger.

\footnotetext{
${ }^{4}$ ASDMAE, Italian Representative at Washington (1901-1909), pacco 147, pos. 3225. From Italian Consulate at New Orleans to Italian Embassy at Washington, 24 July 1901.

${ }^{5}$ ASDMAE, Ibid.
} 
However, the telephone operator told them that the telephone was out of order. Knowing that it was not true, three times they asked to use the telephone, but they were not able to make a phone call. Tirelli reported that the Italians he interrogated were reluctant to talk because they feared for their own lives. Salvatore Liberto, who had miraculously survived the attack, was nineteen and visibly scared. He said that on the night of the lynching it was dark, that he could not see anything but smoke and shadows and did not see how many men were there. ${ }^{6}$

Francesco Cascio, too, was terrified and reluctant to talk. He still lived in the same house with a black woman, his common law wife. According to Cascio, Giovanni Serio was a good man, harmless and tranquil. His son Vincenzo at times could be perceived as an aggressive troublemaker; however, his aggressiveness was verbal, and he was not likely to kill anybody. On the night of the attack, Cascio heard the shots and the Serios calling for help and asking for water, but he did not dare go outside and did not see how many men were out there. ${ }^{7}$ According to Tirelli's report, however, several bullets were found in Cascio's house, thus proving that G.B. Allen had assembled a network of vigilantes to lynch the unfortunate men who had ignored his repeated warnings to leave the area together with their peripatetic horse.

\footnotetext{
${ }^{6}$ ASDMAE, Serie Politica “P” (1891-1916). From Consulate of Italy at New Orleans to Italian Embassy at Washington, 22 July 1901, pacco 680, pos. 856. Tirelli's report was transmitted by chargé d'affairs Francesco Carignani to Foreign Minister Giulio Prinetti and can be found in ASDMAE, Italian Representative at Washington (1901-1909), pacco 147, pos. 3225, 24 July 1891; FRUS, Signor Carignani to Mr. Hill, Washington 24 July 1901, 287-288.

${ }^{7}$ Ibid.
} 
The Italian press in the United States denounced the incident, blaming the racism present in American society, accusing the federal government of dereliction of duty and demanding that it take bold action. The Progresso ItaloAmericano of New York expressed pain and sorrow concerning the violence at Erwin, Mississippi. According to the newspaper, again American hands were red with Italian blood; again the crowd had acted according to a barbaric custom. The savage fury of ferocious violence against free individuals had triumphed; the spilled blood was a further testimony of the flaws of the laws and the shame of old customs. Lynch law, indeed, was the real name of the criminal act originated by a ferocious crowd indulging in atrocious violence, thus spreading fear and horror. $^{8}$

By contrast, newspapers published for American-born audiences commented on the episode at Erwin, Mississippi, with different nuances of disdain. The Herald of New York, for example, emphasized fate and destiny; it defined lynching as an incurable illness that was typical of the United States. Moreover, it commented that Italians, too, once integrated and acquainted with typical local customs, might be at risk to contract yellow fever in Brazil or lynching fever in the United States. ${ }^{9}$

Meanwhile, the Italian chargé d'affairs in Washington, Francesco Carignani, wrote to the State Department, denouncing the ferocious lynching episode. Secretary of State John Hay replied by expressing his sympathy and

\footnotetext{
${ }^{8}$ Il Progresso Italo-Americano, 23 July 1901.

${ }^{9}$ The Herald, New York, 25 July 1901.
} 
ensuring that the case had been referred to the Governor of Mississippi, Andrew H. Longino, for appropriate action. The Secretary of State expressed the disappointment of the federal government over what had occurred at Erwin, Mississippi, and promised that anything humanly possible would be done to bring the guilty parties to justice. ${ }^{10}$ The American press interpreted the protest by the Italian government as a way of obtaining an easy compensation for the loss of life as had happened in similar episodes. ${ }^{11}$ For example, the Daily Progress maintained that the Italian protest undoubtedly derived from the desire to obtain an indemnity as in the cases of New Orleans and Tallulah. ${ }^{12}$

The inquiry ordered by Mississippi Governor Longino showed how difficult it was to find the guilty parties and bring them to justice, as could be seen by the offer of $\$ 100$ compensation to anyone who would volunteer any information in order to identify the lynchers. ${ }^{13}$ Chargé d'affairs Francesco Carignani wrote angrily that days after the lynching had occurred, not even a preliminary investigation had been started in Erwin, Mississippi, to find the murderers of the Serios. According to Carignani, it was obvious that a network of cooperation had contributed to the unfolding of the violence. One important proof was that Giglio and Butero had been denied telephone access to warn the Serios of the dangerous plot to kill them. A request from the Italian embassy for protection of

\footnotetext{
${ }^{10}$ ASDMAE pacco 147, pos. 3225, from the Italian Embassy at Washington to the U.S. State Department, 24 July 1901; FRUS, Department of State, Mr. Hay to Signor Carignani, Washington July 17, 1901, No. 687, 283.

${ }^{11}$ The Washington Post, 22 July 1901.

12 “Italian Government” in Daily Progress, 22 July 1901.

${ }^{13}$ FRUS, 1901, Mr. David J. Hill to Carignani, Washington, July 25, 1901, No. 691, 288-289.
} 
the witnesses derived from awareness of a climate of fear and intimidation that surrounded the Italian community in Erwin. As Carignani wrote, it was imperative to allow the witnesses to testify freely and to provide for their safety as well. "The existence of fear, pressure and intimidation could be easily proved by the fact that even the injured Italian, Salvatore Liberto, claimed that he did not know anything nor did he have anything to declare."14

It must be noted that, since the facts of Erwin did not follow the usual pattern, abducting individuals from jail and lynching them, the American press tried to portray the killing of the Serios as a common episode of bloody murder. However, the Italian consular agent at New Orleans, Carlo Papini, maintained exactly the opposite: he affirmed that it was a lynching rather than a common murder. To support his opinion, Papini noted three important elements: 1) that Dr. Hanna, medical doctor of Glen Allen, had warned Rosario Liberto, brother of the injured individual, Salvatore Liberto, of the immediate danger to the Serios; 2) that the clerk at the telephone company had not allowed Giglio and Butero to make a phone call; and 3) that on the morning of July 9, the overseer of Greenfield plantation, G.B. Allen, had received a phone call, informing him that Vincenzo Serio was on the train going to Erwin. Undoubtedly, this last factor, although reported in an anonymous letter, could be the reason why the clerk at the phone company did not want to allow Giglio and Butero to make a phone call. The episode of Erwin revealed that, once more, the local authorities did not want

\footnotetext{
${ }^{14}$ ASDMAE, pacco 147, pos.3225. From the Italian Embassy at Washington to the U.S. State Department, 30 July 1901; FRUS, 1901, Mr. Hill to Carignani, Washington, July 27, 1901, no. 693, 289; Signor Carignani to Mr. Hill, Washington, July 27, 1901, 289-292.
} 
to act promptly, but had a tendency to delay any legal action in hopes that things would quiet down and everything would be forgotten. ${ }^{15}$

Whether the incident at Erwin would be considered a lynching or a common murder was extremely important as it involved the opportunity to request an indemnity for the families of the victims. It is not accidental that, since the beginning, the American press called what happened at Erwin, a common murder. Also, David J. Hill, Acting Secretary of State, insisted that it was not a lynching, but a simple shooting. Carignani, however, was adamant that what had happened at Erwin was an obviously planned lynching. As he wrote to Foreign Minister Giulio Prinetti, "the same expression commonly used by the Jury summoned by the Sheriff that the victims had died 'by the will of God' was the statement used in all cases of lynching in America." ${ }^{16}$ It is interesting to note that Carignani attached to the same report sent to Prinetti a definition of lynching that had been developed in Ohio, stating that lynching was any illegal act accomplished by a mob. The Ohio law read as follows:

That any collection of individuals, assembled for any unlawful purposes, intending to do damage or pretending to exercise correctional power over persons by violence, and without authority of law, shall be for the purposes of this act regarded as a mob, and any act of violence exercised by them, upon the body of any person, shall constitute a lynching. ${ }^{17}$

\footnotetext{
${ }^{15}$ ASDMAE, Serie Politica "P” (1891-1916), pacco 680, pos. 856. From the Italian Embassy at New Orleans to the Italian Embassy at Washington, report of 1 August 1901.

${ }^{16}$ ASDMAE, Serie Politica "P” (1891-1916), pacco 680, pos. 856. From Italian Embassy at Washington to MAE, 3 August 1901.

${ }^{17}$ ASDMAE, Ibid.
} 
Responding to Carignani's report, Minister Prinetti urged him to hire private detectives in order to discover who had lynched the Italian citizens at Erwin. However, Carignani informed the Foreign Minister that, according to Southern customs and tradition, lynching was quite common, and anyone who either provided information or investigated the facts would be in danger of being lynched himself. Carignani also implied that, in general, Southern investigators did not enjoy a good reputation, and that American authorities usually did not rely on them. Instead, Carignani proposed obtaining from the federal government permission to mobilize secret police at the expense of the Italian government, thus showing the genuine interest of Italy concerning its own citizens. ${ }^{18}$ However, the federal government refused, the rationale being that local authorities were finally conducting an investigation and were looking for the guilty parties in an effective manner. Hence Carignani was led to believe, for the time being at least, that the Mississippi authorities were acting with "greater zeal."19 Minister Prinetti, however, was much less optimistic and quite critical of Carignani's faith in the governor of Mississippi and the federal government. He wrote, "Unfortunately, nothing shows that your sentiments might develop into concrete and effective action." ${ }^{20}$ Prinetti's opinion was based on several factors: the grand jury's statement that the authors of the crime were unknown; the

\footnotetext{
${ }^{18}$ ASDMAE, Italian diplomatic representative at Washington (1901-1909), pacco 147, pos. 3225. From Italian Embassy at Washington to MAE, 14 August 1901. FRUS, Mr. Hill to Signor Carignani, Washington, July 15, 1901, no. 691, 288; Mr. Hill to Signor Carignani, Washington, July 27, 1901, no.693, 289-292.

${ }^{19}$ ASDMAE, Serie Politica "P” (1891-1916), pacco 680, pos. 856. From the Italian Embassy at Washington to MAE, 21 August 1901.

${ }^{20}$ Ibid.
} 
ineptitude of the Mississippi governor; and the constitutional refusal on the part of the federal government to act. Furthermore, the federal government had even refused the request by the Italian government to utilize federal agents who supposedly would not be subjected to "local pressures." The Italian government had offered to do so at its own expense. Prinetti was convinced that such lack of action was a strategy chosen on purpose as the way to slow down any investigation. The foreign minister was convinced that Washington was buying time so that the episode would be forgotten and Italian officials would eventually quiet down. ${ }^{21}$

Moreover, Minister Prinetti pointed out that the case was rather serious in that the Italians killed at Erwin had not been accused of any crime. Hence, there was no apparent cause for the assassination. The episode was anomalous in that it did not follow the usual pattern of a lynching, where popular justice replaced the role of a magistrate in the face of firm conviction that certain individuals had committed or confessed to a crime without being punished for it. The pattern of the Erwin event was unusual, and it did not matter how the episode should be defined, whether a lynching or a common murder; it was not a matter of playing with words and definitions. The case involved the deaths of human beings who had not been indicted for any crimes and had been killed for no apparent reason. It was hard to believe, Prinetti maintained, that "citizens of a

\footnotetext{
${ }^{21}$ Ibid.
} 
glorious republic such as the United States could have acted according to the denial of any form of civil justice."22

Prinetti's pessimism was certainly justified, not only because of the attitudes of both state and federal governments concerning the lynching episode, but also based on evidence that witnesses had been subjected to pressure, harassment, and intimidation. Tirelli's report indicated that Italians in Erwin, Greenville, and Glen Allen were scared to talk; some even regretted having revealed anything that they knew. In particular, the principal witness, the injured Salvatore Liberto, was convinced that if he testified, he would certainly be killed. At first, Liberto had said that he was willing to testify in a court of law; later, however, he refused to testify, as Tirelli wrote, because "he would have been assassinated like a dog in Washington County where he worked to earn a living." Other witnesses, indeed, were also convinced that if they dared to testify, they would end up dead. ${ }^{23}$

Furthermore, the proceedings of the grand jury, convened on September 13,1901 , did not lead to any results, as the case was dismissed for lack of sufficient evidence. In his report, Consul Carlo Papini of New Orleans indicated two plausible causes for such a disappointing outcome: either the testimonies that had been received during the consular investigation had not been repeated in the same manner, or the magistrates had interpreted the testimonies in a way that would safeguard the dignity of the country. Either way, it was not likely that

\footnotetext{
${ }^{22}$ ASDMAE, Italian Diplomatic Representative at Washington (1901-1909), pacco 147, pos. 3225. From MAE to Italian Embassy at Washington, 22 August 1901.

${ }^{23}$ ASDMAE, Serie Politica “P” (1981-1916), pacco 680, pos. 856. From the Italian Consulate at New Orleans to the Italian Embassy at Washington, 11 September 1901.
} 
any future attempt to bring the guilty party to justice was going to succeed. Hence, Papini proposed once again to request an indemnity for the victims' families, based on the fact that the telephone company had refused to call the victims to alert them of the imminent danger. According to Papini, there was sufficient evidence to indict the clerk, a brother of one of the alleged lynchers, who had refused to allow Giglio and Butero to make the phone call. ${ }^{24}$

Undoubtedly, Minister Prinetti was bitter and disillusioned; he was also very worried that there was little possibility that, in the future, Italian citizens residing and working in the United States could be protected. As he put it, "the carelessness and negligence on the part of American authorities could only ensure impunity and lack of punishment for lynchers and could only encourage more violence against Italians in the future." ${ }^{25}$

Prinetti was also aware that the contention was no longer between the Italian government and the State of Mississippi. The issue now would need to be brought to the attention of the federal government by submitting to the State Department a formal protest against denial of justice. Hence, Prinetti asked chargé d'affaires Carignani to write a draft, reserving the right to review it himself before submitting the document to the State Department. ${ }^{26}$ Carignani then proposed that Minister Prinetti include in the document a protest of the violation of the solemn treaty negotiated by the United States and the Italian government,

\footnotetext{
${ }^{24}$ ASDMAE, Ibid. From the Italian Consulate at New Orleans to the Italian Embassy at Washington, 16 September 1901.

${ }^{25}$ Ibid.

${ }^{26}$ ASDMAE, Italian Diplomatic Representative at Washington (1901-1909), pacco 147, pos. 3225. From MAE to Italian Embassy at Washington, 10 October 1901.
} 
pledging mutual protection of their citizens. Carignani even suggested threatening that the Italian government would declare the treaty null and void. Carignani referred to Article III of the Treaty of February 26, 1871, which granted a foreign-born citizen full protection, as the most important one to be included in the protest document. ${ }^{27}$

However, as any hope to bring the lynchers to justice diminished, Italian authorities were forced to admit their failure. Minister Prinetti acknowledged that his initial optimistic expectations had failed miserably. In writing to Carignani, he stated that he had made a mistake when, right after the incident in Erwin, he had hoped that American authorities would not ignore this particular episode of violence. Ultimately, he could only send a statement of protest to Washington, saying that the Italian government had lost any hope that local authorities and magistrates would bring to justice those who had committed the crime in Erwin, Mississippi. ${ }^{28}$

The government of Italy could do nothing but formally protest the violation of existing treaties as well as American denial of justice. There was still hope, however, that in the future Congress would ratify a law conferring jurisdiction on the federal courts in cases of mob violence involving aliens. Prinetti concluded by expressing hope that such a statement of protest might hasten a reform project that so far had been mentioned in presidential messages, but had not yet been

\footnotetext{
${ }^{27}$ ASDMAE, pacco 147, pos. 3225. From the Italian Embassy at Washington to MAE, 10 October 1901.

${ }^{28}$ ASDMAE, Serie Politica “P” (1891-1916), pacco 680, pos. 856. From MAE to Italian Embassy at Washington, 28 October 1901. The text of the formal protest, dated 14 November 1901, is also contained in FRUS 1901, no.702, 297-298.
} 
carried out. ${ }^{29}$ The new Italian Ambassador, Edmondo Mayor de Planches, immediately sent a report to Foreign Minister Prinetti concerning the response by Acting Secretary Hill, who was very sorry about the events in Erwin and was also aware of the need for reparations. ${ }^{30}$

Meanwhile in the Senate of the kingdom of Italy, a heated debate ensued about the humiliation the Italian government had suffered in the aftermath of the Erwin lynching. In particular, former ambassador to Washington Baron Fava, who had become senator in 1901, submitted to Foreign Minister Prinetti a harsh appeal concerning treatment of Italian immigrants in the United States. Fava criticized the verdict issued by the grand jury on September 13, 1901, which contained the usual formula that insufficient evidence had been found to indict anyone; therefore, the men killed at Erwin had died "by the will of God." ${ }^{31}$ Fava further commented on a ritual that was getting more and more ironic if not grotesque. He emphasized that the verdict by the grand jury was identical to all the other ones issued in previous lynchings of Italians in America. In particular, Fava noted that the attitude of the federal government had also been the same as for other lynchings. ${ }^{32}$

According to Fava, the main reason for this attitude could be explained by the U.S. Constitution's separation of powers. Hence, the federal government could only appeal to state governors to abide by existing treaties containing

\footnotetext{
${ }^{29}$ Ibid.

${ }^{30}$ ASDMAE, pacco 680, pos. 856. From Italian Embassy at Washington to MAE, 16 November 1901.

${ }^{31}$ Atti Parlamentari, Senato del Regno, Legislature XXI, Discussion of 20 December 1901.

${ }^{32}$ Ibid.
} 
clauses regarding protection of foreign-born citizens; the government had no real authority or jurisdiction to force state governments to punish individuals who had committed crimes violating such treaties. As for the possibility of an indemnity that the federal government might offer to the families of the lynched Italians, Fava proposed to refuse it. Fava reminded his audience that the U.S. Congress usually offered an indemnity to the survivors so that the American people could feel that they had paid their debt. It would be better to refuse the "blood price," Fava maintained. A refusal of monetary compensation would make a profound impression on the American public. In addition, the Italian public needed to be informed and should understand that refusal of an indemnity would be more honorable than accepting it. Instead of being compensated for loss of lives through humiliating indemnities, Fava proposed putting pressure on the federal government to change the laws so that foreign-born citizens could be protected and existing treaties be respected. ${ }^{33}$

Fava also mentioned that even in the case of Tallulah in 1899, when for the very first time the federal Department of Justice had sent its own envoy to conduct a separate inquiry, the results had been unsuccessful because of the lack of will to bring the lynchers to justice. In fact the authorities at all levels-federal, state, civilian, and military--did not favor the inquiry. Moreover, Fava implied that former Foreign Minister Visconti Venosta had taken a firm stand against the impunity conceded to the assassins of Italians at Tallulah. With a great sense of honor and dignity, Fava maintained, Visconti Venosta had insisted that the federal government accept responsibility for lynchings of foreign-born

${ }^{33}$ Ibid. 
individuals in the United States. In reminding his audience of the dignity and valor of Minister Visconti Venosta, former ambassador Fava obviously implied that the present-day Foreign Minister, Giulio Prinetti, was spineless and acquiescent to the U.S. government's unwillingness to bring lynchers of Italians to justice. Indeed, Fava and Visconti Venosta had coordinated their efforts in trying to pressure the federal government to abide by existing treaties and to protect foreign-born individuals on U.S. soil. Fava explained to his distinguished audience that U.S. President William McKinley had shown sensibility to Italian demands in this area. President McKinley, in two messages to Congress in 1899 and 1900, had urged conferring upon federal courts full jurisdiction in international cases of such nature, stating that, in cases of violence against foreign-born individuals and violation of existing treaties among nations, the ultimate responsibility rested upon the federal, not the state, government. Therefore, it was the responsibility of the federal government to remedy the constitutional flaws that may have led to such deplorable consequences. ${ }^{34}$

Responding to Fava's fiery oratory, Foreign Minister Prinetti said that the Italian government had always acted according to the rules and that it would continue to do its best to protect its citizens working and residing abroad. He did not agree, however, with Fava's aggressive approach because the American people accepted Italians in their own country with "benevolent hospitality." As for the Erwin killing, Prinetti maintained that the Italian government, as well as Italian diplomats in the United States, had done their job with the federal government. Italian officials could not be blamed for insufficient diligence or lack of initiative.

\footnotetext{
${ }^{34}$ Ibid.
} 
The lack of successful results was not their fault. Prinetti agreed with Fava that the "blood price" could not be considered as a substitute for real justice; he also agreed with Fava's suggestion not to request it. However, he did not think that it was right to order the victims' relatives not to accept it, should the U.S. government offer it to them. Therefore, he was not going to submit a request for an indemnity, but neither would he force the victims' relatives to refuse it. $^{35}$

The Italian demand for a federal law to deal with cases of mob violence against foreign-born nationals found some favor in American public opinion, except in the southern states. The Tribune of New York, for example, maintained that more than monetary reimbursement should be given in order to right wrongs and compensate relatives for the loss of their loved ones. In addition, the newspaper praised the Italian government for its patience toward the U.S. government in several instances of violence perpetrated against persons of Italian origin. Furthermore, The Tribune criticized the ineptitude of the U.S. government as well as of the U.S. Congress, which both justified their inadequacy as a constitutional flaw rather than a lack of good will. According to the newspaper, the lack of power of the federal authorities could not be ascribed to the laws, but to the negligence of American legislators in using the powers conferred on them. The U.S. Constitution allowed full powers to the federal government in all cases related to foreign treaties and foreign affairs, but Congress had never acted in order to confer on the federal courts any jurisdiction

\footnotetext{
${ }^{35}$ Ibid.
} 
in cases regarding violation of treaties concerning the rights of foreign-born individuals. ${ }^{36}$

Another New York newspaper, the Evening Star, emphasized that the contention between Washington and Rome could not be resolved by simply awarding an indemnity to the relatives of the lynched Italians. The Italian government, the newspaper pointed out, was not seeking the blood price. In fact, to demand monetary compensation would be equal to pricing a cadaver. The blood price would seem to calculate in dollars and cents the value of the blood of an Italian citizen. The decision to accept money as compensation for the loss of a dear person should be solely the concern of close relatives rather than the responsibility of the Italian government. According to the Evening Star, "Such types of indemnities are destined to the relatives, not to the Italian government, which understands the issue to be much more complex than a matter of money compensation. The Italian government did not really seek the blood price." ${ }^{37}$

One year later, on December 13, 1902, Congress convened. Secretary of State John Hay sent a sympathetic note to President Theodore Roosevelt, reporting the facts of Erwin and the prospect of granting an indemnity to the families. John Hay did not write about the responsibilities of the local authorities, nor anyone else's responsibilities for that matter, let alone the constitutional conflict between federal and state governments in regard to a lynching perpetrated "by an armed crowd." He also stated that, in spite of the cooperation

\footnotetext{
36 “Italy’s Just Complaint,” in The Tribune, New York, 27 December 1901.

37 “Italy’s Contention,” in Evening Star, 25 December 1901.
} 
of Governor Longino of Mississippi with the federal authorities, all efforts to uncover the guilty parties had proved fruitless. Therefore, Hay proposed to grant an indemnity, as had already occurred for the victims of Walsenburg, Hahnville, and Tallulah. He pointed out, however, that such an indemnity should "be considered as an act of grace and without reference to the question of the liability of the United States." ${ }^{38}$ Indeed, the formula was the same as those contained in previous presidential messages in similar circumstances: granting of the blood price without admitting any government responsibilities.

As the U.S. Congress gathered on 15 December 1902 to listen to the address of President Theodore Roosevelt, Ambassador Edmondo Mayor de Planches sent a note to Secretary of State John Hay stating that the Italian government would leave it up to the United States to provide reparations according to its best judgment without the Italian embassy's appearing to be involved. ${ }^{39}$ It was in March 1903 when finally the United States granted an indemnity of $\$ 5,000$ as reparation for the victims of Erwin. ${ }^{40}$

The granting of an indemnity, however, did not suffice to quiet all the polemics that were still going on in Italy about the lynchings and the violence toward Italians in the United States and the lack of communication and cooperation between Rome and Washington. In the Italian Parliament, several

\footnotetext{
${ }^{38}$ FRUS, 57th Cong., 2nd sess. "Killing of Italian Subjects at Erwin, Mississippi.” Message from the President of the United States, Senate, Doc. no.40, 15 December 1902.

${ }^{39}$ ASDMAE, Serie Politica “P," pacco 680, pos. 856. From Italian Embassy at Washington to MAE, 6 December 1902.

${ }^{40}$ ASDMAE, Serie Politica “P,” pacco 680, pos.856. From Italian Embassy at Washington to MAE, 7 March 1903.
} 
representatives participated in the debate. For instance, on April 28, 1903, Representative Cirmeni delivered a speech in which he asked Foreign Minister Prinetti questions about the indemnity for the victims of Erwin, Mississippi. The Foreign Minister's assistant Baccelli responded on May 7, 1903, saying that, in spite of two years having gone by and the continuous, loud protests by the Italian government, he did not consider the contention to be solved yet. ${ }^{41}$

The New York Times reported this discussion that had taken place in the Italian Parliament. The article stated that the Italian government was not involved at all with the acceptance of the indemnity because it could not or would not admit to the "blood price," nor could it force the parties involved to refuse it. The article also reported that two proposals in Congress for federal jurisdiction in cases of mob violence against aliens had not been approved because the states were jealous of their autonomy. In addition, since the number of lynched Italians was relatively small, Southern Representatives in Congress argued that there was insufficient reason to transfer jurisdiction from state governments to the federal government. ${ }^{42}$

The Herald of New York, in its edition of May 8, 1903, also provided coverage of the discussion in the Italian Parliament. The article said that the lynched Italians were turning in their graves, clamoring for revenge and shouting cries of shame for the cowardly Italian officials who accepted the "blood price." On this side of the Atlantic, the U.S. Treasury already had a receipt signed by the

\footnotetext{
${ }^{41}$ Atti Parlamentari, Camera dei Deputati, Discussions, vol. no. 8, April 8, 1903, 7061; and also 7 May 1903, 7306-7307.

42 “Italian Views of the Lynchings in America," in The New York Times, 8 May 1903, 5.
} 
Italian ambassador, accepting on the part of the Serio family the "blood price" of $\$ 5,000$. It was an infamy, said the newspaper, to accept such a small compensation for the lives of two Italians in a premeditated crime. American courts granted much larger sums to American families whose relatives had been killed in a train accident or an explosion. Families of victims of a lynching should receive a much bigger compensation. According to the newspaper, Italian officials, including Ambassador Mayor, were naïve in their understanding of American customs and traditions; they failed to understand the common practice of lynching. ${ }^{43}$

In the Herald article, one could find no optimism that there might be a solution in the near future. The article stated that the American government would never modify its laws in order to include rights for foreign-born citizens, nor would the American people renounce their inclination for lynching Italians. The article also proposed to dismiss Minister Prinetti, who had attempted to appease the very angry ambassador Fava. Prinetti had admitted that the Italian Foreign Ministry had to overlook the news received from Washington that the lynching had been ruled to be "by the will of God" and that the government would have protected immigrants but not with excessive vigor. It would have been much more sensible and appropriate to summon Prinetti to be tried in a court of law for ordering a subordinate to negotiate an indemnity. ${ }^{44}$ The incident in Erwin, Mississippi, would end with the usual "blood price" solution, with a lack of

\footnotetext{
43 “Erwineide,” in The Herald, 8 May 1903.

${ }^{44}$ Ibid.
} 
punishment of the guilty party, and with pessimism about any future improvement in the treatment of foreign-born citizens in the United States.

In 1901, besides the Erwin episode, there was another lynching of an Italian individual, this one in Ashdown, Arkansas. According to the reconstruction of the events by Carlo Papini, consular regent in New Orleans, Giuseppe Buzzotta, originally from Castelvetrano, was killed by a mob of American workers on August 21, 1901. As Papini noted, the very first difficulty he had to face was to counter the official version of the event as it had been reported by the local authorities, which claimed that Buzzotta had provoked the incident. Papini also noted the difficulty of finding any witnesses willing to testify. At first, the Italians seemed to be willing to speak, but then they were intimidated and refused to act as witnesses, so frightened that they would withdraw their depositions. As in other cases, Italians seemed to be willing to testify in front of Italian officials, proclaiming their patriotism; afterwards, however, because of external pressures, they would back down and refuse to testify in a court of law or in front of the grand jury. ${ }^{45}$

One month after the Arkansas lynching, it was still not possible to obtain accurate information concerning what had happened. In fact, Italian Ambassador Mayor wrote to Foreign Minister Prinetti that he had not been able to ascertain whether Ashdown had been a common case of murder or a lynching by a mob, as some believed it to be. Ambassador Mayor also expressed his desire to talk to Secretary of State Hay about this and other cases of blood and violence; whether

\footnotetext{
${ }^{45}$ ASDMAE, Serie Politica "P" (1891-1916), pacco 680, pos. 871. From the Italian Consulate at New Orleans to MAE, 15 October 1901.
} 
or not they were lynchings, these were cases in which Italian nationals had not been protected by either their country of origin or the local authorities, protection to which they were entitled, based not only on existing treaties but also on common human rights. ${ }^{46}$

Once more the trial had not been a fair one, but a real farce. In spite of the initial testimonies by Italians, the judge had ruled that what happened at Ashdown was a case of involuntary or unintentional murder rather than a lynching. Mayor, however, wrote that after the trial, many issues still remained open and unanswered, especially because there were Italian witnesses who could demonstrate, through their testimony, that there had been an intention to murder. Such witnesses, however, had been ignored, or their depositions differed from the original ones that had been obtained at the consulate before the trial took place. ${ }^{47}$

The Italian press in the United States was indignant. It focused on the climate of job competition among various ethnic groups at Ashdown, Arkansas. The Tribune of New York reported how the Italian worker had been killed. According to the article, the Kansas City Southern Railroad employed several Italians; in fact, as in many other places throughout the United States, Italians were in great demand because they worked hard and were considered more productive than Irish drunkards or lazy blacks. The newspaper attributed responsibility for the Ashdown murder to an armed mob of approximately 100 "indigenous" laborers. These local workers were armed with modern rifles with

\footnotetext{
${ }^{46}$ ASDMAE, Ibid. From Italian Embassy at Washington to MAE, 25 November 1901.

${ }^{47}$ Ibid.
} 
which they had terrorized the harmless Italians and then had killed Buzzotta. The article also lamented the lack of justice and mentioned that, as in the case of Erwin, Mississippi, the guilty parties were likely to remain unpunished and never be brought to justice. Furthermore, the article denounced the lack of protection by representatives of the Italian government. ${ }^{48}$ The Italian community in the United States, the newspaper maintained, was still waiting for an energetic response on the part of Italian authorities, their ambassadors and consuls. Otherwise, it was absolutely useless and unnecessary to spend huge sums of money on the upkeep of embassies and consulates. More severe comments stated that once more, Italians in the United States had been treated inhumanely and unjustly. "How long," the newspaper asked, "will our name and flesh be object of such ferocious violence by the scam of American society protected by the connivance of local authorities and by the certainty of being able to go free and unpunished?" 49 The tone of the article was pessimistic about any future improvements in the treatment of Italian nationals in the United States.

Pessimism also describes the feelings of Gino Speranza, an Italian American who had dedicated his life to bettering the condition of Italian immigrants in the United States. Born in Connecticut on April 23, 1872, he had spent his childhood in Verona, Italy. Returning to the United States, he graduated from the City College of New York, received a law degree from the New York University Law School, and was admitted to the Bar in 1896. Because of his

\footnotetext{
48 “Gli Italiani in America,” in The Tribune, New York, 24 August 1901.

${ }^{49}$ Ibid.
} 
interest in Italian immigration and protection of Italian immigrants in the United States, Speranza became legal counselor to the Italian consulate in New York. A prolific writer, his interest in Italian immigrants became the focus of much of his writings. His efforts included the founding of the Society for the Protection of Italian Immigrants and his work for the Investigation Bureau for Italian Immigrants, which was established in 1906 by the Italian government to protect the rights of Italians in America. ${ }^{50}$

Concerned about treatment of Italian workers in West Virginia, the Office of the Commissioner General of Emigration in Rome tasked Speranza, then Secretary of the New York Association of Italian Immigrants, to conduct an inquiry about Italian workers in that state. In May 1903, Speranza prepared a report that indicated Italian laborers in West Virginia were harassed and mistreated. Ironically, shortly after Speranza had completed his report, a lynching of Italians occurred in Davis, West Virginia. ${ }^{51}$

Speranza's report contained a vivid description of the mistreatment endured by Italian laborers in Davis. They had been subjected to intimidation, brutal terrorism, unscrupulous recruiting by Italian bosses, and abuse by shopkeepers in the area. They were basically kept as prisoners in the camp where they worked. Armed men had been hired to prevent workers from attempting to quit, and of course, to intimidate the workers as well. They were kept in a sort of desert in almost complete isolation. To complicate matters

\footnotetext{
${ }^{50}$ Aldo E. Salerno, “America for Americans Only: Gino C. Speranza and the Immigrant Experience.” Italian Americana 14 (Summer 1996): 133-147.

${ }^{51}$ Speranza's report of 15 May 1903 is contained in Bollettino dell'Emigrazione (1903), no. 14.
} 
further, many laborers had joined labor unions. Union members and nonmembers were equal in numbers, thus making it harder to cope with the difficult working conditions and inevitably creating conflict and resentment. Because the Italians did not want to join the labor union, they were looked upon as traitors and not very well liked. ${ }^{52}$

The episode of Davis, West Virginia, was controversial. It occurred in a climate of job competition and ethnic rivalry. It was not a true lynching but, according to Ambassador Mayor, it did have "some of the characteristics of a lynching." ${ }^{53}$ It happened during the night on May 29, 1903. A whole case of dynamite exploded by the entrance of a house where 37 Italians were sleeping. The consequences were dramatic. One individual died immediately; another was injured and taken to the hospital, where he died a few days later. The attack, according to news received by the embassy, had been plotted in order to intimidate the Italians and force them to leave Davis. ${ }^{54}$

In a letter to the Italian embassy, Speranza commented on the event and stated that it would be very difficult to find the guilty parties. According to Speranza, the main reason why the guilty party would likely go unpunished was primarily economic, given the high cost of legal proceedings. ${ }^{55}$ Indeed, in West Virginia, it would be almost impossible to convict leaders of a lynch mob.

\footnotetext{
${ }^{52}$ Ibid.

${ }^{53}$ ASDMAE, From the Italian Embassy at Washington to MAE, 7 June 1903.

${ }^{54}$ Ibid.

${ }^{55}$ Speranza's letter to the Italian embassy is contained in ASDMAE, From the Italian Embassy to MAE, 29 May 1903.
} 
Speranza made an accurate list of necessary expenses, including lawyers, investigators to find witnesses, detectives, and newspapers. Moreover, Speranza emphasized that there was no way, other than the courts, to condemn a lyncher. ${ }^{56}$ Ambassador Mayor was even more pessimistic. He wrote to Foreign Minister Prinetti: "It is good that I repeat it, in order to avoid any illusions about what one can obtain from the courts and the judiciary in the United States." ${ }^{57}$ Ambassador Mayor undertook diplomatic action with the governor of West Virginia so that an investigation would be conducted in order to find the guilty parties and bring them to justice. The ambassador took similar steps with the State Department in the hope that the federal government might contact the governor and local authorities in West Virginia. Like Speranza, Ambassador Mayor was pessimistic about obtaining an indemnity and bringing the perpetrators to justice. As Ambassador Mayor wrote, it would probably be rather naïve to hope that the killers could be found and that an indemnity could be obtained from them. It was likely that the guilty parties would remain unknown, but even if they were found, they would probably be poor workers unable to pay an indemnity. Furthermore, Mayor noted that, for the time being, the issue of an indemnity was unpopular in Italy as could be seen from the accusations by Senator Fava against Foreign Minister Prinetti in the case of the facts of Erwin, Mississippi. Mayor further wrote that even though an action by the Italian embassy with the U.S. government might be successful, it would not quiet down

\footnotetext{
${ }^{56}$ Ibid.

${ }^{57}$ ASDMAE, From Italian Embassy to MAE, 7 June 1903.
} 
the ongoing debate in Parliament that the "blood price" was a humiliation and unsatisfactory reparation for the violence. ${ }^{58}$

Italians would continue to be harassed and mistreated in the following decades. Besides lynchings, cases of peonage--the forced detention of workers-were rather common, especially in the South. Italians were often victims of such ignominious practice. In 1908, the Italian envoy responsible for Italian immigration in New Orleans, Count Gerolamo Moroni, was sent to the New Orleans consulate in order to conduct an investigation concerning lynchings of Italian citizens in the South. Moroni's writings shed light on some of these cases and added to an understanding of the discrimination to which Italians were subjected. ${ }^{59}$

That very climate of ethnic hatred and discrimination was at the root of the lynching that occurred in Tampa, Florida in 1910. As Moroni stated in his report, the lynchings or attempted lynchings of Italians were due to an economic downturn provoked by a reduction in jobs and wages that had provoked nativeborn American workers to resent and to fight competition by foreign-born workers. Furthermore, ethnic hatred and deep dislike of the foreign-born, especially among low-class Americans, fueled resentment and aggressive behavior. $^{60}$

\footnotetext{
${ }^{58}$ ASDMAE, Ibid. From Italian Embassy at Washington to MAE, 20 June 1903.

59 "The Peonage in the South of the United States,” report by Royal Representative of Italian Immigration to New Orleans, Gerolamo Moroni, in Bollettino dell'Emigrazione (Rome, 1910).

${ }^{60}$ Ibid.
} 
Another good source of information is a report prepared by John Savarese, consular agent at Tampa, who, in March of 1908, sent to Rome his response to a series of questions that the Italian Foreign Ministry passed to all consulates in the United States. The data gathered by Savarese provides a good picture of the Italian community in Tampa, amounting to 1,600 families, with about 6,000 to 7,000 Italians, originating mainly in Sicily or Campania. Twothirds of the Italians in the Tampa area were employed in the cigar-making industry, but there were also peasants, fishermen, and barbers. ${ }^{61}$

The writings of Fara Forni and Luigi Villari, two Italian representatives who travelled in Florida in the early 1900s, also shed some light on the working conditions of Italians employed in the Florida cigar industry. According to their report, Tampa was the most important Italian community in Florida, including about 7,000 Italians, most originally from the Sicilian towns of Palermo, Girgenti, and Piana dei Greci; a few were from the Naples area. The majority worked in one of the 33 cigar factories, utilizing tobacco imported from the island of Cuba. The job, according to Forni and Villari, was not easy to learn. The training lasted from six to eight months, but it took at least three years for a laborer to become fully competent. During the training period, workers were not paid well; actually workers who wanted to be employed full time often had to pay an entrance fee in order to be hired. A great number of Sicilian women were employed in the cigar factories; they had acquired a good reputation as reliable workers. According to

\footnotetext{
${ }^{61}$ ASDMAE, Diplomatic Representative in Washington (1848-1901), pacco 150.
} 
the report, some of these immigrant Sicilian women earned as much as $\$ 25.00$ per week, while average workers earned $\$ 16.00$ or $\$ 18.00$ weekly. ${ }^{62}$

It fell to Vice Consul Gerolamo Moroni of the New Orleans consulate to investigate the lynching of two Italians, Angelo Albano and Costanzo Ficarotta, on the night of 20 September 1910 in Tampa, Florida. Moroni conducted a serious inquiry and produced a thorough report that is not only informative, but also credible.

According to Moroni, the city of Tampa had a population of 50,000, including black and white Americans, Hispanics, Cubans, and Italians. The Italian community living in Tampa had the worst reputation in the whole country because it contained numerous common delinquents as well as mafia members. In addition, a long strike in the cigar industry had further fueled anti-Italian sentiment in the city. The main reasons for the lynching, according to Moroni, were a number of episodes of wrongdoing that had remained unpunished because of a lack of witnesses as well as the three-month long strike that had severely damaged the cigar industry in Tampa. Those factors set the stage eventually leading to the lynching of Italians in Tampa. ${ }^{63}$

Moroni described the activities of the "Black Hand" within the Italian community, which operated undisturbed because of the connivance of prominent

\footnotetext{
62 "Gli Italiani nel distretto consolare di New Orleans,” Report of Fara Forni, with Additional Notes by Luigi Villari, Consular Representative for Emigration, in MAE, Commissioner General for Emigration, Emigrazione e Colonie, III, America (Rome: MAE, 1909).

${ }^{63}$ ASDMAE, Serie “Z” USA, pacco 33, pos. 27/2. "Relazione sul linciaggio di Tampa, Florida.” From the Italian Consulate of New Orleans, 8 October 1910; George E. Pozzetta, "Italians and the Italian General Strike of 1910," in Pane e Lavoro: The Italian American Working Class (Toronto: Multicultural History Society of Ontario, 1980), 29-46. Robert P. Ingalls, Urban Vigilantes in the New South: Tampa, 1882-1936 (Knoxville: The University of Tennessee Press, 1988), 96-99.
} 
individuals in the Tampa community. Such "prominents," according to Moroni, were the plague of all Italian communities in America. In Tampa, the "prominents" had formed a committee of public safety in order to eradicate the "Black Hand." Soon, the members of the committee of public safety created a system of "outlaw police," who operated with arrogance shortly after the violence; such arrogance increased, thus bringing further dishonor upon the Italian community in Tampa. The committee imposed payments on the Italians based on their individual incomes and sent anonymous letters of threats and intimidation. Needless to say, the local authorities did nothing because the threats concerned Italians and their internal illegal affairs. ${ }^{64}$

According to Moroni, unlawful acts committed by Italians usually remained unpunished because of the unwillingness of people to testify against individuals of the same ethnic group. However, also at fault were the police because they too were corrupt men appointed by county voters for a period of four years and, therefore, unwilling to upset local sensibilities, he maintained. ${ }^{65}$

Moroni also criticized the judiciary system and the impotence of the police in front of lawyers who, when they were well paid, became capable of obtaining impunity for the defendants. Unpunished delinquents, continuous wrongdoing, and, lastly, the long strike culminated in popular indignation and a lynching. In fact, it became easy to exploit the climate of indignation for those who wanted the

\footnotetext{
${ }^{64}$ ASDMAE, Serie “Z” USA, pacco 33, pos. 27/2. “Relazione sul Linciaggio di Tampa, Florida,” From the Italian Consulate of New Orleans to MAE, 8 October 1910.

65 ASDMAE, Ibid. "Relazione sul Linciaggio di Tampa, Florida.” From the Italian Consulate at New Orleans to MAE, 8 October 1910.
} 
cigar makers' strike to fail. "The businessmen and cigar manufacturers in Tampa took the opportunity to crush the strike." 66

However, there were several legitimate reasons to strike, the primary one being the horrible conditions under which laborers were forced to work in cigar factories. Moroni denounced how polluted the work environment was in cigar factories. "The laborers who work in cigar factories," he wrote, "are often ill with tuberculosis as they work in a very hot environment that is impregnated with nicotine." ${ }^{n 7}$ The most serious factor in escalating the conflict between management and labor was the refusal on the part of factory owners to increase wages, thus leading to a strike and shutting down of the factory. ${ }^{68}$

Since he was an aristocrat (like most diplomatic representatives), Moroni was not inclined to justify the strikers nor the union leaders who were mainly responsible for the outbreak of the strike. In fact, he deemed the International Union of Cigar Makers, a branch of the American Federation of Labor, responsible for the whole controversy. According to Moroni, union leaders sought only to increase union membership rather than to right wrongs; nor were they interested in protecting the rights of the laborers. They were after the interests of the union. In fact, union leaders understood that between 10,000 and 13,000 well-paid workers did not belong to the union. Hence, it was in the interest of the

\footnotetext{
${ }^{66}$ ASDMAE, Ibid.

${ }^{67}$ ASDMAE, Ibid.

${ }^{68}$ ASDMAE, Ibid.
} 
union itself to get workers involved and lure them to join the union so that it could generate good monthly income through soaring membership. ${ }^{69}$

Moroni also accused the union leaders of being responsible for the economic downturn that had set in as a direct consequence of the long strike they had promoted. An economic crisis also meant a social crisis in a city where the cigar industry was the main source of employment. As Moroni wrote in his report, the three-month-long strike had taken a heavy toll reducing income considerably in the city of Tampa, with most of the population suffering tremendously. Business and trade had come to a halt, and anti-immigrant sentiment was at an all-time high. The overall atmosphere was so electrified that it could explode at any time. ${ }^{70}$

According to Moroni, there were 6,000 or 9,000 strikers in all, for many cigar workers had left for Havana, Key West, New Orleans, or Sanford before the strike had started to work in other factories. As often occurs during strikes, relations among workers quickly deteriorated. The strikers, Moroni wrote, had shifted from peaceful protest to forbidding their fellow workers to leave town, to harassing newly hired workers considered "scabs," and even to throwing stones at trains. Ultimately, strike leaders had attempted to murder Joe Cosio, nicknamed "Spagnolo," mistakenly thinking him to be his brother, who was Vice President of the Manufacturers' Association. ${ }^{71}$

\footnotetext{
${ }^{69}$ ASDMAE, Serie “Z” USA, pacco 33, pos.27/2. "Relazione sul linciaggio di Tampa, Florida.” From the Italian Consulate at New Orleans to MAE, 8 October 1910; FRUS 1913, "The Tampa Lynching.

Memorandum by the Solicitor of the Department of State,” April 13, 1911, 613-615.

${ }^{70}$ ASDMAE, Ibid.

${ }^{71}$ ASDMAE, Ibid.
} 
Vice Consul Moroni in his report about the events described in detail the unfolding of popular rage that eventually led to the lynching. He recalled the attempted murder of J.F. Easterling, accountant of the Bustillo Brothers \& Diaz cigar factory. The attempt originated with Easterling's shooting in the air at the very beginning of the strike in that factory. Furthermore, in order to counterattack, Easterling had hired some new workers or "scabs." Shortly after, two Italians were accused of the murder attempt against Easterling, based on testimonies of doubtful reliability. The witnesses indicated that Costanzo Ficarotta and Angelo Albano had been present, Moroni wrote, but there was not enough evidence nor were there reliable witnesses to establish that the two were guilty of attempted murder. Furthermore, Moroni wrote that, in the Italian community, there were actual rumors that a Cuban citizen who had moved to New York was the one who had shot Easterling. However, the reluctance of Italians to testify, Moroni maintained, presented the greatest obstacle to his conduct of a serious and effective inquiry. In fact, no Italian in the community had been willing to name the Cuban who allegedly fired on Easterling. ${ }^{72}$

Although the two Italians probably had not fired upon Easterling, for many, no proof was necessary of their guilt. In fact, Ficarotta was a killer by trade and could have been paid to shoot or to stir up matters. Albano might have been present, but only coincidentally, as he was going around the block on his bicycle.

\footnotetext{
${ }^{72}$ ASDMAE, Ibid.
} 
Moroni had reason to believe that Deputy Sheriff Keaggin had fabricated the evidence against Ficarotta and Albano simply because they were Italian. ${ }^{73}$

Undoubtedly, the mob had acted with the connivance of local authorities, who had done nothing to stop it, thus becoming accomplices to the violence. These details, Moroni maintained, were clear indicators that the mob had not acted spontaneously, but that the lynching had been carefully planned. The two Italians were arrested and taken to jail. They were surprised to be taken into custody, but they were not worried. However, Moroni bitterly commented that it was not possible to find any reliable witness who would speak freely and who would not be scared and intimidated. Furthermore, even statements released by the American authorities could not be considered reliable. In fact, the statements by Deputy Sheriff Ewans were out and out lies. Even the testimony by a firefighter, Bryan, could not be taken into consideration as he was one of the lynchers. ${ }^{74}$

Moroni also indicated in his report a series of factors that led him to believe that the police were involved in the lynching. On the night of September 20, 1910, a group of 20 or 25 people speaking perfect English took the two Italians from the jail. The men involved were beyond any doubt English-speaking Americans and not Italians who wanted to get rid of dangerous delinquents, as the local authorities insinuated. The Sheriff Robert Jackson fired only a few shots in the air in a half-hearted attempt to break up the mob. Furthermore, the police

\footnotetext{
${ }^{73}$ ASDMAE, Ibid.

${ }^{74}$ ASDMAE, Ibid.
} 
faked an attempt to follow the group, and then passed by the site of the lynching without seeing anything. Only several hours later, at 23:30, did they "casually" discover the bodies of the two unfortunate Italians. Moroni reiterated that a lynching usually is an act committed by citizens with the support and connivance of the local police. One had only to examine carefully all lynchings in the United States up to that date to reach that same conclusion. ${ }^{75}$ Moroni ironically lamented that Italians were naïve, that they were not yet familiar with the tradition and practice of lynching, but that some day in the near future they would probably learn it from the "civilized" Americans. ${ }^{76}$

That the episode occurred so quickly was further proof that the lynching had been planned and that the site had been chosen in advance, Moroni bitterly commented. The two Italians had been hanged back to back, and a pipe had been placed in Ficarotta's mouth. On Albano's body, the mob had placed a sign written in English as a warning to seven other Italians that the same could happen to them. According to Moroni, the seven Italians listed on the warning sign were naturalized American citizens who, soon after the lynching, received letters of intimidation and a notice of eviction. Moroni indicated that five of the seven individuals had police records, but there was no evidence that they had participated in the strike. In fact, only two Italians had been involved in the strike,

\footnotetext{
${ }^{75}$ ASDMAE, Serie “Z” USA, pacco 33, pos. 27/2. From the Italian Consulate to MAE, 8 October 1910.

${ }^{76}$ ASDMAE, Ibid.
} 
Giovanni Vaccaro and Angelo Leto, and they had already left for New York. They were not in Tampa on the day when Easterling was shot. ${ }^{77}$

Moroni also reported that public opinion in Tampa was overwhelmingly on the side of the lynchers, as could be seen in the local press. The vice consul mentioned an article published in the Tampa Tribune that declared that the people of Tampa had shown with the lynching that they would not tolerate homicides committed because of human greed and that the two Italians were victims of public indignation. ${ }^{78}$

Moroni asserted that the main causes of the lynching episode were the interests of the cigar industry, the damages provoked by the long strike, and the need for a lesson that would end the strike and restore order. According to Moroni's report, once the industrialists, the merchants, and the police realized that the strike was going to have disastrous consequences, they understood that threats and intimidation of the strikers were about to shift to real attempts on their lives. Consequently, the "prominents" decided, with the connivance of the authorities, that a lesson was needed to intimidate the masses, and they conveniently found "victims" in the two Italians. Indeed, the two Italians were the right people. Ficarotta especially was hated and deemed dangerous; his death would be considered a relief for the community. Albano was not a delinquent but was a friend of Ficarotta. He had never violated the law, but he was cheering for the strikers. Albano did not realize that, not being an American, his obvious

\footnotetext{
${ }^{77}$ ASDMAE, Ibid.

78 “A Lynching and a Lesson,” The Tampa Tribune, 22 September 1910.
} 
sympathy for the strikers and friendship with the much-hated Ficarotta was dangerous. ${ }^{79}$

According to Vice Consul Moroni, there was no possibility of finding the lynchers and bringing them to justice. There was no evidence against the citizens of West Tampa; Italians did not want to testify, and Americans would not incriminate themselves in the plot they had conceived in order to get rid of two dangerous individuals and, at the same time, to intimidate the strikers. Moroni was also convinced of the connivance of the authorities in the lynching. Beyond any doubt, the police had been involved both in the plotting and in the unfolding of the violence. There was no evidence, however, to substantiate his strong allegations. Even without evidence, data, and witnesses, Moroni maintained that the police knew what was about to happen yet took no measures in order to protect the two Italians. In fact, the police handed the two unfortunate Italians to the lynchers as if it was not their duty to protect the Italians' lives. Furthermore, it was clear that no steps were taken even to attempt to identify the guilty parties. ${ }^{80}$

Soon after the lynching of Albano and Ficarotta on the night of September 20, Consul Carlo Papini of New Orleans telegraphed the Italian Ambassador in Washington, Montagliari, that he feared more violence and that the Italian community wanted to hold a "mass meeting." The ambassador's reply showed that he was more worried about the possibility of more violence than about the violence that had already happened. Ambassador Montagliari urged Papini to act

\footnotetext{
${ }^{79}$ Ibid.

${ }^{80}$ Ibid.
} 
with calm dignity and caution, to discourage any protest or demonstration, and to send honorary Vice Consul Moroni from New Orleans to West Tampa to conduct an inquiry. The embassy, on the other hand, would appeal to the State Department as well as to the governor of Florida to provide protection and to conduct an investigation to detect the guilty parties and bring them to justice. Florida Governor Albert W. Gilchrist replied that the two Italians had already obtained U.S. citizenship and that an investigation "concerning last night's unfortunate occurrence" was already in progress. ${ }^{81}$

In writing to the Italian Foreign Minister, Marquis Antonio di San Giuliano, Ambassador Montagliari expressed serious concern about the safety of the Italian community in West Tampa. He wrote that the episode of West Tampa was very serious, the most serious one since the incident in Erwin, Mississippi in 1901. The ambassador was also very upset because local newspapers indicated that some Italian citizens might have been directly involved in the lynching. ${ }^{82}$

According to Ambassador Montagliari, the Italian community residing in West Tampa was divided. It contained both good and evil elements including several members of the Mafia. Yet the city had a reputation for tranquility and order. The Italian community was rather large, consisting primarily of Sicilians. In this community, as in many other communities in the United States, there were only a few Italians who had been able to reach comfortable and respectable

\footnotetext{
${ }^{81}$ Telegram and correspondence are contained in ASDMAE, Serie “Z,” USA, pacco 33, pos. 27/2. From Italian Embassy at Washington to MAE, 20 September 1910.

${ }^{82}$ Ibid.
} 
positions. Unfortunately, some Italians in the West Tampa community were unreliable and made a living off their fellow Italians through blackmail. ${ }^{83}$

In the fall of 1909, Tampa had seen the ruthless murder of two Italians by fellow Italians. That episode, the ambassador maintained, was linked to the lynching of Ficarotta and Albano on September 20 as well as to the recent strike at the Bustillo Brothers and Diaz cigar factory. Unfortunately, the practice of lynching blacks and whites alike was common in Florida as well as in other southern states, Ambassador Montagliari commented. ${ }^{84}$

The Italian embassy, however, could not take any initiative until the nationality of Ficarotta and Albano had been ascertained. Were they Italian or American citizens? On 23 September 1910, a letter from the ambassador to Foreign Minister San Giuliano informed the latter that while Ficarotta had indeed obtained American citizenship, Angelo Albano was still a legal Italian. Furthermore, some newspapers had published articles that questioned whether Italians had committed the lynching. The Italian ambassador also sent a note to the U.S. State Department, on the same date, in which he protested that the local authorities had failed to take all necessary measures to protect the two individuals while they were being detained. The two Italians were suspected only of having injured an accountant of the Bustillo \& Diaz cigar factory. Instead of defending the two unfortunate individuals who had been handcuffed, authorities abandoned them without even attempting to halt the premeditated lynching.

\footnotetext{
${ }^{83}$ Ibid. From Italian Embassy at Washington to MAE, 22 September 1910.

${ }^{84}$ Ibid.
} 
Indeed, the ambassador pointed out the irresponsibility of the local authorities in letting things happen. As he put it, "Not only did they fail to prevent the lynching, but also to employ any energy in trying to stop the unfortunate event." ${ }^{85}$

Furthermore, Ambassador Montagliari informed Foreign Minister San Giuliano he had sent Moroni to Tampa to conduct an investigation. Moroni had reported that the situation in Tampa was calm and tranquil, but that the authorities had been reluctant in looking for the guilty parties. Even more humiliating, Moroni indicated in his report, was that photographs of the lynching were being sold in Tampa. Moroni had protested such a humiliation and had urged the mayor of Tampa to forbid the sale of the photographs. Moroni had also reported that the two lynched individuals did not enjoy a good reputation in the community. They both had reputations as unreliable individuals who often resorted to extortion and blackmail. ${ }^{86}$

The Italian community in Tampa had protested vigorously about this episode of violence against Italians. Montagliari informed the foreign minister that Italian newspapers had printed fiery articles about the event. Moreover, on a daily basis the embassy continued to receive protests from different associations or private individuals, denouncing the violence and accusing local authorities of not having taken any measures to prevent it. ${ }^{87}$

\footnotetext{
${ }^{85}$ ASDMAE, from Italian Embassy at Washington to MAE, 23 September 1910; FRUS, The Tampa Lynching. Memorandum to the Solicitor of the Department of State, April 13, 1911, File No.

311.651T15/18, 613-615, includes the whole history of the occurrence from September 20, 1910, to April 13, 1911.

${ }^{86}$ ASDMAE, Ibid. From Italian Embassy at Washington to MAE, 23 September 1910.

${ }^{87}$ ASDMAE, from Italian Embassy at Washington to MAE, 26 September 1910.
} 
Moroni's report put a rapid end to the sale of the photos. The Tampa Daily Times published an article on 27 September 1910, titled "The Governor Stops Sales of Lynching Pictures," indicating that because of the protests of the Italian vice-consul, the Florida governor had issued the order to Sheriff Robert A. Jackson. Instead, on 28 September 1910, The Tampa Morning Tribune revealed that one of the two recently killed Italians, Angelo Albano, had committed perjury in swearing that he was an American citizen born in New Orleans. In truth, Albano still held Italian citizenship and an Italian passport and had registered illegally to participate in 1909 elections in Florida.

Having received all appropriate documentation proving that one of the two Iynched individuals was of Italian nationality, Ambassador Montagliari sent a note to U.S. Secretary of State Philander C. Knox, informing him that Angelo Albano was born in Italy, not in New Orleans, as the Florida authorities had maintained. The ambassador also requested that the guilty parties be sought and, at the same time, he denounced the dubious conduct of the authorities in Tampa. Although the Italian ambassador had no intention of accusing the Florida authorities of being accomplices in the lynching, he was aware that said authorities had not even attempted to look for those who had committed the lynching of September 20, nor did they show any intention of punishing the guilty parties, had they been found. ${ }^{88}$

\footnotetext{
${ }^{88}$ A copy of the letter by Ambassador Montagliari to U.S. Secretary of State P.C. Knox to Foreign Minister A. di San Giuliano is contained in ASDMAE, From Italian Embassy at Washington to MAE, 2 October 1910; FRUS, Secretary of State, P.C. Knox to Italian Ambassador, Washington, March 1, 1913, no. 381, 617.
} 
Montagliari sent a copy of his letter to Secretary of State Knox to Marquis San Giuliano, together with a report in which the ambassador informed the foreign minister of his meeting with U.S. Undersecretary of State Adee. As Montagliari reported, Adee was inclined to believe that the Tampa authorities were at fault and that the ambassador's allegations were credible. Furthermore, Montagliari added that Adee had expressed a clear intention to ask the Attorney General to conduct a federal inquiry concerning the lynching that had occurred in Tampa and determine whether the local authorities had failed to make an effort to locate the guilty parties. According to Ambassador Montagliari, based also on the report prepared by Vice Consul Moroni, the Tampa police did not intend to find the guilty parties and bring them to justice; rather, the Tampa authorities had wanted to get rid of Ficarotta as a persona non grata anyway, as well as of his friend Angelo Albano. Hence the violence turned out to be the perfect opportunity to eliminate dangerous and unwelcome individuals in the community. ${ }^{89}$

However, having ascertained that one of the victims was indeed foreignborn, the federal authorities had the right to act directly, even though the local authorities might not agree with any federal interference in what they deemed to be the state government's jurisdiction. Indeed, the Florida authorities continued to claim that the two victims were American citizens and that, therefore, it was up to state authorities to decide how to deal with the event.

Unsurprisingly, when it was released, the verdict by the grand jury stated that no individuals guilty of the macabre hanging had been found. In New

\footnotetext{
${ }^{89}$ Ibid. ASDMAE, from Italian Embassy to MAE, 2 October 1910.
} 
Orleans, Consul Carlo Papini wrote to Ambassador Cusani Confalonieri that it was likely that whoever had committed the crime would go unpunished. Papini commented that he had never expected any individuals to be found guilty and punished; he had expected some individuals to be tried as suspects and then freed for lack of evidence or witnesses. That the authorities had declared it impossible to find any guilty individuals for the lynching, Papini stated, was an enormous humiliation for Italy and the Italians. ${ }^{90}$

Consul Papini also blamed John Savarese, the Italian consular agent at Tampa, for the humiliating consequences of the Tampa lynching. Papini, in concurrence with Moroni, sent his strong accusations of Savarese's failures to the Italian ambassador in Washington, Cusani Confalonieri. In turn, the ambassador endorsed the allegations and wrote to Italian Foreign Minister San Giuliano. Papini had accused Savarese of absenteeism and lack of interest in uncovering the truth. Count Moroni was outraged pointing out that Savarese enjoyed a position of preeminence among the Tampa elite. Because of Savarese's status, he probably had many chances to get to the facts; however, he did not want to jeopardize his own position and, at the time of Count Moroni's inquiry, had failed to play an active role, thus playing into the hands of the local authorities, who had a vested interest in seeing Moroni's inquiry fail. ${ }^{91}$

The Tampa events--long economic recession, a seven-month strike in the cigar industry, a lynching and macabre hanging of two Italians--had major

\footnotetext{
${ }^{90}$ ASDMAE, From Italian Consulate at New Orleans to Italian Embassy at Washington, 28 January 1911. ${ }^{91}$ Ibid.
} 
consequences. Besides the national and international repercussions of the Tampa lynching of 1910, one major consequence was a considerable drop in Italian immigration to Florida. In a report of 1911, Vice Consul Moroni at New Orleans wrote that Italians residing in Florida in 1908 amounted to 7,000 to 8,000; during the cigar industry strike, many of those Italians left Florida and returned to Italy or went to work somewhere else in the United States. By 1911, the number of Italians living and working in Florida had shrunk to about 5,000. ${ }^{92}$

As for the Italian community in Tampa--about 4,000 out of a total population of $45,000-$-its living conditions worsened considerably. Before the strike, Moroni wrote, several Italians were doing well; however, many had been forced to dig into their savings or borrow money in order to survive during the seven months that the strike dragged on. Moroni, however, was optimistic about the future and hoped that conditions would eventually return to normal and that the cigar industry would flourish again. Although less numerous, Italian laborers were still employed in the Tampa cigar industry after the strike. As Moroni wrote, "The majority of Italian workers are employed in the manufacture of cigars; they are about 3,000 while before 1908 they were approximately 6,000 of 13,000 workers." ${ }^{93}$

Ambassador Cusani really did not want to submit a request for an indemnity to the U.S. State Department; rather he preferred to wait for Secretary of State Knox to propose a settlement for the incident. In fact, Cusani sent Knox

\footnotetext{
${ }^{92}$ Moroni, “L’emigrazione italiana in Florida,” in Bollettino Emigrazione, 1913, 1.

${ }^{93}$ Ibid.
} 
a copy of the letter that former Secretary of State Blaine had sent to Imperiali, chargé d'affairs at the Italian embassy in Washington, following the New Orleans lynching of 1891. In that letter, Blaine had proposed to Imperiali that the Italian government accept an indemnity from the federal government. Cusani wrote to Foreign Minister San Giuliano that he hoped for a settlement similar to the one after the New Orleans lynching. ${ }^{94}$

Cusani, however, was less militant and less combative than former Ambassador Fava. He claimed that, after the episode of Tampa, the position of the Italian embassy was much weaker than it had been in the aftermath of the New Orleans episode. In New Orleans, the guilt of the police had been demonstrated. It was much more difficult to prove responsibility by the Tampa authorities. $^{95}$

About two months after the Tampa incident, on 3 November 1910, a Mexican was lynched in Texas. Cusani considered contacting the Mexican embassy in Washington, recognizing that the case had striking similarities to that of Tampa. The victim was a Mexican citizen, Antonio Rodriguez, who had been accused of having violated an American woman. Rodriguez was abducted, beaten, and set on fire while still alive. "It is evident," he maintained, "that our countries [Mexico and Italy] have common interest in these two cases." 96

\footnotetext{
${ }^{94}$ ASDMAE, From Italian Embassy at Washington to MAE, 17 February 1911.

${ }^{95}$ Ibid.

${ }^{96}$ ASDMAE, From Italian Embassy at Washington to MAE, 12 November 1910.
} 
Without wavering, the U.S. State Department refused to admit any responsibility in the events of Tampa. Moreover, Secretary of State Knox compared the Tampa episode not to the Texas incident but to another act of violence in Catania, Sicily, involving two American sailors. Puzzled, Cusani wrote to Foreign Minister San Giuliano that, on the one hand, the U.S. State Department seemed inclined to propose a settlement for the violence at Tampa; on the other hand, it countered those negotiations by comparing what occurred in Tampa with what happened in Catania on 24 October 1909. Although Cusani was aware that more information was really needed to evaluate both episodes and to counter the federal government's argument, he was convinced that the two episodes of Tampa and Catania were totally different and that no real connection between the two existed. While he had no doubt that the case of Tampa was a lynching, the violence against the two American sailors in Catania had been provoked by a fight. ${ }^{97}$ Cusani was indeed persistent; his persistence succeeded in keeping the two episodes separate.

Eventually, Cusani accepted once more the "blood price" as a settlement of the violence. It did not really matter whether the state of Florida or the federal government paid the indemnity. "It is of little or no importance," he said, "which authority pays the indemnity. But there is a possibility that the State Department might hide behind a refusal by the State of Florida. In that case, they must be

\footnotetext{
${ }^{97}$ ASDMAE, From Italian Embassy at Washington to MAE, 12 November 1910; FRUS, April 13, 1911, 615.
} 
reminded that the indemnity for the New Orleans lynching was not paid by the state of Louisiana, but by the federal government." 98

It took longer than usual, however, to receive payment of the "blood price" in the case of the lynching in Tampa, Florida. Not until two years later did President Woodrow Wilson finally recommend that Congress vote in favor of an indemnity of $\$ 6,000$ for the lynching of Italian citizen Angelo Albano. As in all previous cases, Wilson emphasized that the indemnity must be considered as "an act of grace and without reference to the question of liability of the United States." Thus, the words used by Secretary of State William Jennings Bryan on 24 June 1913 in recommending that Congress grant an indemnity did not mention or imply any kind of responsibility or negligence on the part of the Florida authorities. He mentioned, however, previous lynchings for which the "blood price" had also been awarded--Walsenburg, Hahnville, Tallulah, and Erwin-stating that the Italian government had requested an indemnity of $\$ 6,000$ for the family of the victim in the Tampa incident. ${ }^{99}$

In the U.S. Congress, a heated debate ensued concerning granting an indemnity to an individual who had not even attempted to obtain American citizenship. An indemnity would mean that Albano's family would enjoy a privilege that was usually denied to U.S. citizens. Reporting about the debate to Foreign Minister San Giuliano, Cusani noted that the main issue he had expected the U.S. Congress to discuss was the amount of the indemnity to be awarded

\footnotetext{
${ }^{98}$ ASDMAE, From Italian Embassy at Washington to MAE, 2 March 1911.

${ }^{99}$ FRUS, 1913, Message from the President of the United States, 26 June 1913, House of the Representatives, 63rd Cong.,1st sess., Doc. No. 105, 619-620.
} 
rather than whether to grant it; that issue had not been addressed. Cusani noted that the sum awarded by the federal government for previous cases amounted to approximately $\$ 2,000$. However, he tried to take advantage of the delay in granting the indemnity by arguing for the more substantial indemnity. Obviously he was aware that there would be difficulties in obtaining a greater amount. ${ }^{100}$ Eventually, the House of Representatives approved awarding the Albano family an indemnity of $\$ 6,000$. Cusani considered this amount a personal victory. He was satisfied that, taking advantage of the delay, he had been able to triple the indemnity to be awarded to the victim's mother.

Ambassador Cusani contacted all Italian consuls in the United States, urging them to notify other Italian officials in their jurisdictions. According to Ambassador Cusani, Italians working and residing in the United States would appreciate the outcome in the Albano case. Italians usually complained about cases of lynching that, in general, were resolved with a humiliating indemnity and failure to punish the murderers. Hearing of the Albano indemnity, they would stop complaining about the weakness and shortcomings of the Italian embassy in protecting Italian workers in the United States. ${ }^{101}$

Wisely, Cusani did not praise the accomplishments of the embassy at Washington, but the success of the Italian government in Rome. He urged the Italian consuls in the U.S. to emphasize the role of the Italian government rather than the accomplishments of the embassy. It would be more effective, Cusani

\footnotetext{
100 ASDMAE, From Italian Embassy at Washington to MAE, 8 September 1913.

${ }^{101}$ ASDMAE, From Italian Embassy at Washington to all Italian Consulates in the United States, 20 November 1913.
} 
maintained, for the Italian press in the United States to praise the energetic action by the royal government without even mentioning the Italian embassy in Washington. ${ }^{102}$

Although no individuals were ever brought to justice for the murder of Ficarotta and Albano, Ambassador Cusani emphasized that, in this particular case, the Italian government had taken bold action and had succeeded in obtaining a better indemnity for the family of the one victim who had kept Italian citizenship, Angelo Albano. Nevertheless, no matter how Ambassador Cusani interpreted the outcome of the lynching of Tampa, Florida, it was true that, once more, the violence had resulted in the "blood price."

Undoubtedly diplomacy had scored a victory, but so too had racism, racial hatred, and dislike of the Italian race. Anti-Italian sentiment had produced violence in Erwin, Ashdown, Davis, and Tampa. Anti-foreign sentiment always seemed to filter through a specific stereotype when Italians were involved, for in the eyes of Americans, they bore the mark of Cain. Especially in the South, Italians always prompted images of violent murderers as well as mysterious "Black Hand" societies. Were the Serios, father and son, guilty of doing well in their fruit and vegetable business? Were they guilty of not leaving town after being warned to do so by their neighbor, who was annoyed with their peripatetic horse, or were they guilty of being friends with a fellow Italian man who lived with a black woman? What about Angelo Buzzotta, who was killed by a mob of coworkers employed by the Kansas City Southern Railroad? Authorities were not

\footnotetext{
${ }^{102}$ ASDMAE, Ibid.

${ }^{103}$ ASDMAE, Ibid.
} 
able to ascertain the reasons for his death. Ethnic rivalry and economic competition were probably the cause of the death of Italian workers who were blown up while they were sleeping in Davis, West Virginia. Again ethnic hatred and discrimination precipitated the lynching of Costanzo Ficarotta and Angelo Albano in the midst of a long cigar-makers' strike in Tampa, Florida. In that case, too, frightening images of "Black Hand" and hidden knives led to the violence.

What might be the roots of so many episodes of ethnic hatred and violence? Into the first decade of the twentieth century, a significant number of southern and eastern European immigrants continued to pour into the United States. The predominance of "new" over "old" immigration was now becoming apparent to Americans in every part of the country. Their whiteness was often called into question. According to Alabama Congressman Thomas Abercrombe, "their color differed greatly from that of the Anglo-Saxon race."

In the early twentieth century, southern and eastern Europeans went westward to the Pacific Coast to work together with Mexicans and Asians for railroad companies or in mills and fisheries. Italians and Portuguese were successfully competing with the Japanese in intensive truck farming. At the same time, a significant number of southern and eastern Europeans immigrated to the South. Outside of New Orleans and adjacent areas, the South had seen hardly any "new" immigrants prior to the very end of the nineteenth century. By the early 1900s, however, they had become so common that the number of southern and eastern Europeans more than doubled between 1900 and 1910 and Italian

\footnotetext{
${ }^{104}$ Higham, Strangers in the Land, 167-168.
} 
farmhands and railroad workers became noticeable and visible. In 1910, the new immigration constituted one percent of the white population in the South and 5.6 percent in the Pacific States. ${ }^{105}$

The great tide from southern and eastern Europe was pouring into the North; the whole area below the Mason and Dixon line had only half as many new immigrants as did New York City. Native-born individuals in the South were extraordinarily sensitive to complexion and caste and looked on the newcomers as, in a way, in between the white and black races. The "in-between-ness" of the newcomers was often pointed out as a disturbing factor that might disrupt the order of things. The new foreigners did not seem to adapt to southern traditions and values. In particular, the Italians' willingness to associate with blacks seemed to be quite disturbing; the Italians endangered the pattern of white supremacy and the order of society. Italians often worked side by side with blacks on Louisiana plantations or allowed blacks into their stores or even lived with black women in their homes. In Louisiana, the whites tried to maintain the color line by prohibiting Italian children from attending white schools. ${ }^{106}$

According to John Higham, by the early twentieth century, the South was becoming the nativist champion par excellence; its spokesmen were soon to be

\footnotetext{
${ }^{105}$ Higham, Strangers in the Land, 381; Rowland T. Berthoff, “Southern Attitudes towards Immigration, 1865-1914,” Journal of Southern History XVII (1951): 332-336.

${ }^{106}$ Higham, Strangers in the Land, 169. See also Gail Bederman, Manliness and Civilization: A Cultural History of Gender and Race in the United States, 1880-1971 (Chicago: University of Chicago Press, 1991); Matthew Frye Jacobson, Whiteness of a Different Color: European Immigrants and the Alchemy of Race (Cambridge, MA: Harvard University Press, 1998); Jennifer Guglielmo and Salvatore Salerno, Are Italians White? How Race is Made in America (New York: Routledge, 2003); Cynthia Skove Nevels, Lynching to Belong: Claiming Whiteness Through Racial Violence (College Station, TX: Texas A\&M University Press, 2007).
} 
prominent in every anti-foreign movement. ${ }^{107}$ Southern congressmen and senators were soon to play a prominent role in opposing attempts in Congress to pass a much-needed federal anti-lynching law to protect foreign-born nationals in cases of mob violence in the United States. Constitutional doubts, states' rights, and strong convictions that aliens in the United States were guaranteed the same rights of protection and the same degree of justice provided for American citizens could not be overcome in Congress. Yet, throughout the unfolding of the contention between Italy and the United States concerning protection of Italian nationals on U.S. soil, Italian diplomats and politicians pursued a course of prudence and moderation, and, with the exception of the New Orleans affair, they made efforts not to disrupt relations between the two countries.

\footnotetext{
${ }^{107}$ Higham, Strangers in the Land, 167.
} 


\section{CHAPTER VI}

THE ITALIAN RESPONSE:

\section{THE PROBLEM OF PROTECTION OF ALIENS AND RELATIONS BETWEEN}

\section{ITALY AND THE UNITED STATES}

The numerous episodes of lynching of individuals of Italian origin that occurred in the United States strained relations between the United States and Italy. Relations between the two countries became more and more difficult, opening the way to various and complex diplomatic incidents. In particular, the 1891 New Orleans lynching signaled the beginning of long and difficult years of contention between Rome and Washington. Although the New Orleans lynching was not an isolated event, and had been preceded by other episodes of virulent violence and ethnic hatred, by the 1890s U.S. and Italian relations had become exasperating and explosive. The New Orleans lynching stretched the Italian bent toward diplomatic caution and pragmatism to its very limits.

The events of New Orleans soon attracted attention on the international scene and provoked indignation because eleven individuals, who had been tried in a court of law and acquitted, had been forcibly taken from the prison and lynched with the obvious connivance of the police. The episode of New Orleans went beyond the usual public outrage; it opened the door to a serious crisis in American-Italian relations and provoked nationalistic fervor in the Italian Parliament, culminating in the recall of the Italian ambassador to Rome. It seemed that the winds of war were blowing, and the diplomacy reached a serious point of friction. Furthermore, following the episode of New Orleans, for 
the first time the Italian embassy in Washington, instructed by the Foreign Ministry in Rome, attempted to put pressure on the U.S. Congress, demanding punishment of those involved in the attack.

The Italian Foreign Minister, Antonio di Rudinì, suggested to Ambassador Francesco Saverio Fava that he appeal to U.S. Secretary of State James Blaine (1889-1892) and demand reparations, i.e., that the guilty parties be brought to justice and the U.S. government pay an indemnity to the victims' families. The foreign minister was blunt in demanding that Fava request "immediate and energetic steps" to protect the endangered Italian colony, to punish the guilty severely, and to be persistent in obtaining more than a simple letter stating regret for the unfortunate facts of New Orleans. ${ }^{1}$

A distinguished diplomat, Baron Fava served as ambassador to Washington for 20 years, from 1881 to 1901 . He began his diplomatic career under the Bourbons and then continued serving as ambassador under the Savoy dynasty after the unification of Italy. Prior to serving as ambassador to the United States, he had served in Brazil and Rumania. The greatest challenge of his entire diplomatic career was the "New Orleans affair." 2

Fava undertook the task with cautious determination. Following instructions, he brought the affair to the attention of Secretary of State Blaine, who telegraphed the Governor of Louisiana, Francis T. Nicholls. Blaine stated that the treaty between the United States and Italy guaranteed to the subjects of

\footnotetext{
${ }^{1}$ ASDMAE, Serie Politica "P” (1891-1916), pacco 445. Telegram from MAE to the Italian Embassy at Washington, 19 March 1891; FRUS 1890-91, 52nd Cong., 1st sess., 665.

${ }^{2}$ Sidney Sonnino, Diario, 1866-1912 (Bari: Laterza, 1972), 407.
} 
the latter "the most constant protection and security for their persons and property and that President Benjamin Harrison hoped the governor would cooperate with him in maintaining the obligations of the United States toward the Italian subjects in his state so that further violence might be prevented. ${ }^{3}$

The Italian government claimed that the U.S. federal government failed to comply with the Treaty of Commerce and Navigation mutually agreed upon on 26 February 1871 . The treaty contained a reciprocity clause providing for mutual protection of foreign-born citizens as well as equal treatment of foreign-born and native-born individuals residing in different states of the Union. Based on the treaty, then, foreign-born individuals were not entitled to any special treatment or privilege compared to native-born individuals. Both foreign-born and native-born were entitled to equal protection under the law. However, with the New Orleans lynching of 1891, it became apparent that the individual states of the Union enjoyed autonomy in various areas of government, including the judiciary. Such autonomy was enshrined in the U.S. Constitution and the federal government could not undermine it. This factor implied a fundamental conflict between the right of the single states to manage their own affairs and handle the judiciary autonomously and the responsibility of the federal government to comply with international treaties that guaranteed the right of foreign-born citizens to receive mutual protection as provided by the reciprocity clause. ${ }^{4}$

\footnotetext{
${ }^{3}$ FRUS 1891, Correspondence in Relation to the Killing of Prisoners in New Orleans, Telegram, Blaine to Governor Nicholls, March 15, 1891; Telegram Governor Nicholls to Blaine, March 16, 1891, FRUS, 52nd Cong, 1st sess., 658.

${ }^{4}$ ASDMAE, Trattati e Convenzioni fra il Regno d'Italia e i governi esteri, vol. IV (1 January 1870 to 1 January 1873), Rome, 1874, 144-155; United States-Italy, Treaty of Commerce and Navigation (February 26, 1871) in Malloy’s Treaties, 1:969.
} 
Not only did the Italian government ask for official reassurance by the United States that the guilty parties would be brought to trial, but also that it would recognize the principle that an indemnity was due to the relatives of the victims. However, the U.S. government refused to promise any reparations. An intense correspondence went on between the two governments. Blaine stated that whether or not there was a violation of the treaty was a question that President Benjamin Harrison, with sufficient facts submitted to him, would take into consideration. The position taken by the federal government was that if, after proper investigation, a case was established for relief to be granted to the families of the Italian subjects who had lost their lives by lawless violence, it would be submitted for the consideration of Congress. ${ }^{5}$

Relations between Rome and Washington continued to deteriorate because of the federal government's reluctance to reply to Rome's demands. Foreign Minister Rudinì, who at the time served also as Prime Minister, was determined to hold a hard-line position. In fact, almost daily he had to endure strong attacks from members of Parliament accusing him of weakness in dealing with the United States concerning the New Orleans lynching. Furthermore, Italian public opinion became more and more "impatient," and rightly so. Rudinì was also subjected to pressure and criticism from the Italian press. For example, the newspaper La Riforma compared him with his predecessor, Francesco Crispi,

\footnotetext{
${ }^{5}$ FRUS. 1891-1892, 52nd Cong., 1st sess., 665-667, 671, 672, 674, 712. Robert T. Devlin. Commentaries on the Treaty Power under the Constitution of the United States (San Francisco, Bancroft-Whitney Co., 1908), 527.
} 
claiming that the latter was a much stronger leader while serving both as Prime and Foreign Ministers during his tenure. ${ }^{6}$

Although he was always scrupulous in implementing the policies suggested by Rudinì, Ambassador Fava tended to be more moderate and more "diplomatic" than his direct superior. Fava favored a more moderate approach so that the federal government would have time to deal with the embarrassing case of New Orleans without having to face pressure from the Italian government as well. Fava's attitude, however, led Rudinì to deem the ambassador more supportive of Blaine's attitude than of Rome's demands. Rudinì wrote in a telegram to Fava, "I am sorry that you are now a defender of the U.S. federal government."7 A whole controversy began unfolding and eventually, on 31 March 1891, the Italian ambassador was recalled and diplomatic relations with the United States were broken off.

The American press discussed the contention between the Italian and American governments in a nationalistic manner, not only arguing against the attempts by a foreign government to interfere with the laws and institutions of the United States, but also emphasizing cultural and language barriers between representatives of both countries. The Herald of New York, for example, emphasized the misunderstandings between Secretary of State Blaine and

\footnotetext{
${ }^{6}$ ASDMAE, Serie Politica “P” (1891-1916) pacco 445, 24 March 1891

${ }^{7}$ ASDMAE, Ibid. Telegram from MAE to Italian Embassy at Washington, 24 March 1891.
} 
Ambassador Fava and also communications problems between Fava and Rudinì. $^{8}$

A few days after the breaking of diplomatic relations, The Philadelphia Inquirer published an anti-Italian cartoon. The cartoon ridiculed several prominent Italian government officials such as Foreign Minister Rudinì, Ambassador Fava, and even King Umberto I. In the cartoon, Rudinì was portrayed as an itinerant musician, King Umberto I as a street vendor of peanuts, and Fava as a monkey holding the plate for coin collection. Next to the mentioned cartoon, another one showed King Umberto and Rudinì, clearly offended, sharpening their knives (a reference to the Italian Mafia), implying that Italy was preparing for a conflict with Uncle Sam. Furthermore, an article published in the same newspaper reported that the king of Italy was offended because of a cartoon that ridiculed his majesty and the dignity of Italy, and Italian blood was boiling hot. ${ }^{9}$

Minister Rudinì had "the most painful impression" concerning the deplorable status of relations between Italy and the United States, the deterioration of relations between the two countries, and the cold, detached attitude of Secretary of State Blaine concerning the "legitimate Italian demands of bringing the guilty parties to justice." ${ }^{10}$ Rudinì was aware that Blaine was correct in demanding that violation of existing treaties must be ascertained before the federal government could consider the granting of indemnities to the victims'

\footnotetext{
8 “Il malinteso tra Mr. Blaine e il barone Fava,” The Herald, New York, 3 April 1891.

9 “King Humbert Gets Mad,” in The Philadelphia Inquirer, 12 April 1891.

${ }^{10}$ ASDMAE, Serie Politica “P” (1891-1916), pacco 445. From MAE to Italian Embassy at Washington, 28 April 1891.
} 
families. The foreign minister, however, did not even try to conceal his disappointment. He wrote, "It is repugnant to us to even think that, in his mind, the violation of treaties must be demonstrated. Italian citizens acquitted by an American jury were kept in jail with a pretense and murdered by a lynching mob, and no preemptive measures were undertaken to provide for their defense. What other evidence did the federal government need to understand that a treaty sanctioning mutual protection of citizens had been violated?" ${ }^{11}$ According to Rudinì, the Italian government had acted fairly. It was now up to the federal government to unravel its own tangled relationship with the member states of the Union. "It is time to end the unfortunate controversy," the foreign minister maintained. "Public opinion, always sovereign judge, will point out the rightful solution to this problem. We have already asserted our rights and we will continue to assert them. On the other hand, the federal government must consider whether it might be convenient to depart from the single states of the Union, which are not responsible in matters of foreign policy, so that the federal government may honor foreign treaties." ${ }^{12}$

The diplomatic controversy surrounding the New Orleans lynching also strained relations between Rudinì and the American Ambassador to Rome, Albert G. Porter. The foreign minister and the ambassador held a meeting to discuss the New Orleans affair, which turned out to be a heated exchange of very diverse opinions concerning what needed to be done on the part of each

\footnotetext{
${ }^{11}$ Ibid.

${ }^{12}$ Ibid.
} 
government. As Rudinì wrote to the Italian embassy in Washington, "According to Porter, Secretary of State Blaine deems that foreign-born residents in the United States are not to be considered a privileged category." ${ }^{13}$ Furthermore, Blaine believed that the treaties between the United States and Italy guaranteed equal treatment of Italian and American citizens; therefore, Italian nationals should not be treated any differently than American citizens. Rudinì, however, maintained that such a statement was a mere abstraction and, in the case of New Orleans, it implied that U.S. law allowed the murder of American citizens while they were locked up in a state prison. ${ }^{14}$

Porter told Rudinì that the American people were very disappointed in the Italian government. American public opinion, he maintained, was "irritated" with the tone of Italian diplomacy and all the pressure placed by the Italian government on Washington without allowing enough time for discussion among representatives of both countries. ${ }^{15}$ Porter's main argument was that American laws did not allow the federal government to interfere in any way with the government of the State of Louisiana. Italy therefore could not demand that the federal government conduct any action contrary to the government's own laws. Rudinì, however, deemed it unacceptable that the federal government could disassociate itself from any responsibility for actions by the governments of the member states of the Union. Such lack of federal responsibility, according to

\footnotetext{
${ }^{13}$ ASDMAE, Serie Politica “P” (1891-1916), pacco 445. From MAE to Italian Embassy at Washington, 28 May 1891.

${ }^{14}$ Ibid.

${ }^{15}$ Ibid.
} 
Rudinì, was absurd. If that was the case, Rudinì maintained, the federal government should not negotiate any foreign treaties. ${ }^{16}$

It was also true that Washington would consider any action by Rome against the State of Louisiana as an act of hostility against the government of the United States, not as an action against one single state. In his report to the Italian embassy concerning his encounter with Porter, Rudinì emphasized just that. Porter had told him that the federal government would consider an act of hostility against Louisiana as a declaration of war against the United States. While admitting to some flaws in American institutions, Porter argued that tradition and customs in the United States did not allow changes unless such flaws were officially proved. Although Porter had repeatedly stated that American public opinion was "irritated" with pressure by the Italian government, Rudinì wrote in his report to the embassy that the Italian government had pursued a moderate and conciliatory approach. In fact, Italian authorities had agreed to recall Consul Corte from New Orleans. Considered to be overzealous and "persona non grata," Corte was "sacrificed" to show that the government of Italy favored conciliation rather than confrontation. Rudinì wrote, "Our conciliatory spirit was such that Consul Corte was recalled from New Orleans to explain his own behavior and to clarify any doubts that he might not have been conciliatory enough in dealing with the New Orleans crisis." ${ }^{17}$

\footnotetext{
${ }^{16}$ Ibid.

${ }^{17}$ Ibid.
} 
It fell upon Marquis Guglielmo Imperiali, chargé d'affairs at the Italian embassy in Washington after Fava had been recalled, to reply to Rudini's report concerning his meeting with Ambassador Porter in Rome. Imperiali disagreed with some of Porter's statements referring to the American public's reactions to the facts of New Orleans. According to Imperiali, Porter's statements might mirror the desires of American leaders, but were not realistic. Imperiali maintained that American public opinion had accepted the facts of the New Orleans lynching without being horrified by the way the massacre had occurred. According to Imperiali, American public opinion tended to agree that the individuals massacred at New Orleans on 14 March 1891 were a gang of thieves and assassins, members of the Mafia, who had been terrorizing the city of New Orleans and obstructing the course of justice; consequently, although protesting the means, the majority approved the results, either publicly or deep down in their hearts. ${ }^{18}$ Furthermore Imperiali described the actions of the federal government as a "vast and permanent electoral agency" in that each decision always seemed to be dictated by the number of votes that might be lost or gained at the next election. Imperiali also emphasized that the American press had not reacted to coverage of the facts of New Orleans by the foreign press. Imperiali wrote, "For the majority of the American people the rest of the world does not even exist nor is the U.S. government concerned about what happens on the other side of the Atlantic." ${ }^{19}$

\footnotetext{
${ }^{18}$ ASDMAE, Ibid. From the Italian Embassy at Washington to MAE, 15 June 1891 ${ }^{19}$ Ibid.
} 
Imperiali was a realist. He suggested that the Italian government should attempt to obtain an indemnity for the victims' families. However, he had misgivings concerning any attempts by the federal government to intervene and bring the guilty parties to justice. In fact, the U.S. Constitution did not allow the federal government much room to maneuver and interfere with state governments. To hope for any departure from tradition, according to Imperiali, was not very realistic and, even if the President of the United States recommended it, such a departure would provoke a very strong wave of nationalism. Americanism would prevail and would turn against the executive branch, which would be accused of listening to foreigners who had dared to criticize the Constitution. ${ }^{20}$

The line of division between the federal and state governments had always been a fine one. Traditionally, the Republican Party favored a strong federal government and curtailment of the autonomy of states' powers. However, according to Imperiali, it was unthinkable that the House of Representatives, which in the next Congress would probably gain a Democratic majority, would approve a measure that would be contrary to the fundamental principles of the Democratic Party. Furthermore, the measure would take aim at the State of Louisiana, which was Democratic, and New Orleans, its "citadel." ${ }^{21}$

As for restoring diplomatic relations after the recalling of Fava from Washington and the subsequent recalling of Ambassador Porter to the United

\footnotetext{
${ }^{20}$ Ibid.

${ }^{21}$ Ibid.
} 
States, Imperiali emphasized the differences in strength and power between the two countries. Although Italy was the offended party, considering its weaknesses, Italy should be the one to take the first steps toward reconciliation. Since Italian interests in the United States were much bigger than American interests in the kingdom of Italy, Imperiali suggested that the Italian government should take the initiative to restore diplomatic relations. ${ }^{22}$ The American public always tended to be nationalistic, as did the American press. For example, according to Imperiali, the recalling of Ambassador Fava had been interpreted as a sign of arrogance and as a menacing provocation. ${ }^{23}$

Imperiali also reported what Secretary of State Blaine told Ambassador Fava before he was recalled to Rome: "I do not acknowledge to anyone the right to give orders to the American people." ${ }^{24}$ According to Imperiali, Blaine had told Fava before his departure, "I am not concerned about foreign opinion of the U.S. institutions; I cannot change the U.S. Constitution nor can I violate it." Such words," he wrote, "definitely expressed the way of thinking of the majority of the American people concerning the U.S. Constitution." 25 According to Imperiali, Blaine was well aware that Fava was likely to repeat his own words verbatim, which would be welcomed with great favor by an American public, which was

\footnotetext{
${ }^{22}$ Ibid.

${ }^{23}$ Ibid.

${ }^{24}$ Ibid.

${ }^{25}$ Ibid.
} 
affected with Americanism, thus showing how well the federal government defended the rights and the dignity of the American people. ${ }^{26}$

Like Ambassador Fava before him, chargé d'affairs Imperiali always tried to moderate the bellicose Rudinì, explaining to him that Italy could not and should not go to war with the United States. Therefore, the whole issue of restoration of diplomatic relations should be presented in such a way that the federal government could not do anything but accept it. Basically, Imperiali suggested finding a way to end the diplomatic controversy that would be honorable for Italy. Rudinì agreed but wanted to wait until Secretary of State Blaine showed a willingness to reopen negotiations concerning the reparations issue. ${ }^{27}$ Rudinì hoped that the U.S. Congress might engage in a discussion concerning New Orleans and that it might consider the granting of indemnities, thus ending the whole diplomatic controversy. ${ }^{28}$

Does the federal government have the power of jurisdiction in a case of mob violence perpetrated against aliens? The question was presented directly to the State Department in the case of New Orleans, and, at that time, a negative answer was given. At the request of the Italian government that the federal government conduct an investigation and institute criminal proceedings, the matter was submitted to the Department of Justice for an opinion. The reply was

\footnotetext{
${ }^{26}$ Ibid.

${ }^{27}$ Ibid. From Italian Embassy at Washington to MAE, 25 August 1891

${ }^{28}$ Ibid. From MAE to the Italian Embassy at Washington, 25 September 1891.
} 
that in absence of federal legislation, the federal government had no power of jurisdiction over such a case. ${ }^{29}$

Were the Italians lynched in New Orleans entitled to protection by virtue of the treaty made between the United States and Italy? According to Article III of the treaty, the citizens of both contracting parties must receive the most constant protection and security of their persons and property and enjoy the same rights and privileges granted to natives. Hence, the Italian subjects had the right to expect that the local authorities would protect them from acts of violence by a mob and would keep them safe while they were held in custody. New Orleans, however, showed that local or state authorities had been unable or unwilling to give sufficient protection to the Italians while in custody. An examination of the diplomatic correspondence shows that the demands of the Italian government were two-fold: that the federal government bring the guilty parties to justice, and that the federal government pay an indemnity to the heirs of the victims. The Italian government was very insistent in its demands for reparation and, because of failure to obtain a prompt compliance to this request, it withdrew its ambassador, Baron Fava. Once an indemnity was paid and accepted by the Italian government, diplomatic relations were resumed. Still the question of responsibility remained unresolved. In view of the treaty provisions as well as the rules of international law, the federal government was responsible for crimes against foreigners and could not shift responsibility for those crimes to state authorities so that punishment for acts of violence by a mob rested with a state.

\footnotetext{
${ }^{29}$ FRUS, 1891, 52nd Cong., 1st sess., 686.
} 
The federal government had no authority to punish the individuals who had committed the crime. The absence of such a power was due to the failure of Congress to enact appropriate legislation rather than from lack of a constitutional provision. $^{30}$

The lynching at New Orleans and the demands of the Italian diplomatic representatives prompted a movement in Congress to enact federal legislation on mob violence. Undoubtedly President Benjamin Harrison contributed to ending the controversy. In his annual message of December 9, 1891, the President mentioned the New Orleans case. Harrison stated that the lynching of Italian subjects by a mob of citizens in New Orleans was a deplorable incident, but it did not originate in any general animosity toward the Italian people or in any disrespect for the government of Italy. The fury of the mob was directed against men who were supposed participants in the murder of a city official. The President maintained that some proposals growing out of this incident were worthy of Congress's attention. He said that it would be appropriate for Congress to make offenses against treaty rights cognizable in the federal courts, but this action had not been taken and thus, federal officers and courts had no power to intervene. In cases of international law, officers of a state charged with police and judicial powers should be regarded as federal agents so as to make the government responsible for their acts in those cases where the federal government would have used its constitutional powers to define and punish

\footnotetext{
${ }^{30}$ Charles H. Watson, "Need of Federal Legislation in Respect to Mob Violence in Cases of Lynching of Aliens,” The Yale Law Journal, vol. 25, no.7 (May 1916): 576.
} 
crimes against treaty rights. ${ }^{31}$ President Harrison's proposal stemmed from acknowledgement of failure by Congress to act and not from a want of inherent power in the national government. ${ }^{32}$

Following the President's recommendation, Senator John Sherman introduced a resolution instructing the Committee on Foreign Relations to draft a bill to protect the treaty rights of aliens. Such a bill was introduced in the Senate on March 1, 1892. The bill provided that "any act committed in any state or territory in the United States and such foreign country and constituting a crime under the laws of the state or territory shall constitute a like crime against the United States and be cognizable in the federal courts." ${ }^{33}$ Basically, the bill provided that where acts that were crimes under the laws of the states were committed against aliens in violation of their treaty rights, the offenders should be prosecuted in the federal courts, but that the statutes of the state should define the crime, prescribe the punishment, and regulate the rules of evidence and procedures. $^{34}$

Opponents of the bill, such as Senator George Gray of Delaware, contended that, although the bill drew its authority from the treaty-making power, treaties are subject to the same constitutional limitations as are laws and may not

\footnotetext{
${ }^{31}$ FRUS 52nd Cong., 1st sess. Message of President Benjamin Harrison to the Senate and the House of Representatives, December 9, 1891.

${ }^{32}$ FRUS, 1891, Ibid., President Benjamin Harrison Annual Message to Congress, 9 December 1891.

${ }^{33}$ FRUS 1891, Ibid. President Benjamin Harrison, Annual Message to Congress December 9, 1891; President Harrison's message was also mentioned by President McKinley in his Annual Message to Congress, December 5, 1899, FRUS 1899, XXII; J.B. Moore, Digest of International Law, Washington, GPO, 1906, vol. VI, 847.

${ }^{34}$ Cong. Rec., 52nd Cong., 1st sess., 23: 4549.
} 
trespass into the field reserved to the states. In adopting state laws, there would be an unconstitutional delegation of the legislative power of the federal government to the states. There would be different punishments for the same crime in each of the forty-four states, based on the variations in state laws, which seemed inequitable. Removal of cases to the federal courts would give aliens an advantage over citizens. Opponents also objected to the bill's contributing to a considerable growth of federal jurisdiction over the large number of aliens compared to state jurisdiction over citizens. Citizens would be subjected to double standards for the same crime. Furthermore, the Constitution did not contain any specific grants of such power to Congress. ${ }^{35}$

Defenders of the bill, such as Senator John Morgan of Alabama and Senator Frank Hiscock of New York, defended it on numerous grounds. First, Congress has constitutional powers to pass laws to enforce treaties. Second, the Constitution granted the federal government jurisdiction over cases involving aliens. In addition, it had been a long established practice for Congress to adopt state laws, even though they varied in specific contents; the subjecting of persons to trial by both state and federal sovereignties for the same act could not be considered double jeopardy. This bill was limited to those aliens claiming a right under a treaty. The bringing of these prosecutions in federal courts was not essentially different from the right of federal officers to remove suits brought against them from the state to the federal courts. ${ }^{36}$

\footnotetext{
${ }^{35}$ David O. Walter, “Legislative Notes and Review Proposals for a Federal Anti-Lynching Law," The American Political Science Review, vol. 28, no. 3 (June 1934): 437.

${ }^{36}$ Ibid.
} 
Several months passed, interest in the bill died down, and it never came to a vote, even though President Benjamin Harrison, in his annual message to Congress the following year, reiterated his view that federal anti-lynching law was a much-needed remedy in order to bring under federal jurisdiction punishment of parties guilty of offenses against treaty rights. ${ }^{37}$

Congress did approve, however, a proposal to grant substantial indemnities to the victims' families even though the federal government quickly denied any direct responsibility for the unfortunate incident. In a note dated April 12, 1892, Secretary of State Blaine informed Marquis Imperiali that the President had instructed the Secretary to tender the amount of $\$ 24,330.90$ to be equally distributed to the families of the victims. Blaine stated that, while the injury was not inflicted directly by the U.S. government and without reference to the question of liability, it was the "solemn duty" as well as the "great pleasure" of the federal government to pay a satisfactory indemnity. Blaine also expressed the hope that all memory of the unhappy tragedy might be effaced. ${ }^{38}$ Marquis Imperiali accepted the indemnity; he stated that he did so "without prejudice to the judicial steps which it may be proper for the parties to take" and that, by the instructions of his government, diplomatic relations between Italy and the United States were fully reestablished. ${ }^{39}$

\footnotetext{
${ }^{37}$ FRUS 1891-1892, 52nd Cong., 1st sess., President Benjamin Harrison, Annual Message to Congress, December 6, 1892.

${ }^{38}$ FRUS 1891-1892, Blaine to Marquis Imperiali; Imperiali to Blaine, April 12, 1892, 727-728.

${ }^{39}$ Ibid.
} 
Legal suits were brought by relatives of the individuals killed in the New Orleans lynching to recover damages, but the court decided that the killing of a human being by a mob allowed to congregate by the negligence of municipal officers does not render the municipal corporation liable for damages in the absence of a statute. The treaty between the United States and Italy then in force guaranteed to the citizens of either nation in the territory "the most constant protection and security for their persons and property." The treaty also guaranteed that "they [Italians] shall enjoy in this respect the same rights and privileges as are or shall be granted to the natives on their submitting themselves to the conditions imposed upon the natives." ${ }^{40}$ The court decided that this treaty was applicable so far as it required that the rights of an Italian mother suing for the death of her son should be determined as if she were a native citizen of the United States. $^{41}$

It must be observed that in a note of April 14, 1892, to Imperiali, Secretary of State Blaine clarified that indemnities had not been granted to the victims' families by virtue of the treaty in force between the two countries. Private individuals coming voluntarily to reside in the U.S. were protected by the same laws as native-born citizens of the United States. Those individuals had, in fact, the same advantages as citizens of the state in which they happened to reside. ${ }^{42}$

\footnotetext{
${ }^{40}$ Treaty of 1871, Art. III.

${ }^{41}$ Devlin, Commentaries on the Treaty Power of the Constitution, 530

${ }^{42}$ FRUS, 1891, 52nd Cong., 1st sess., 1891, 683.
} 
Throughout the diplomatic controversy engendered by the New Orleans lynching, the U.S. government adopted a firm attitude concerning its responsibility for prompt punishment of the guilty parties and reparations for those Italian citizens not yet naturalized in America. The controversy was never about the guilt or presumed guilt of the New Orleans Italian Mafia. It focused on the failure of the United States either to provide adequate protection for Italian subjects in its custody or to admit to this inadequacy. The U.S. government was unable to offset the resistance of the Louisiana authorities, yet all government officials--including President Harrison and Secretary of State Blaine--refused to accept any national responsibility for the failures of law and order in Louisiana. ${ }^{43}$ Because of its magnitude, the New Orleans affair created an important precedent, leading to similar diplomatic controversies and similar reparations for later lynchings. Its most important outcome, however, was the beginning of a movement in Congress to pass a federal anti-lynching law to protect aliens from mob violence.

Subsequently, the lynching of Italian subjects in Walsenburg, Colorado, in 1895 ended with the granting of indemnities to the victims' families. On that occasion, too, by an act of Congress of June 30, 1896, "out of humane considerations and without reference to the question of liability therefor," Congress made an appropriation to the Italian government of $\$ 10,000$ for indemnity to the heirs of three subjects killed by a mob and two others seriously injured in the State of Colorado. In this case the Italian consul at Denver,

\footnotetext{
${ }^{43}$ Marco Rimanelli and Sheryl Postdam, eds. The 1891 New Orleans Lynching and U.S.-Italian Relations: A Look Back (New York: Peter Lang, 1992), 144-145.
} 
Giuseppe Cuneo, reported that, soon after the event, the local authorities had tried to cooperate with his efforts to secure the prosecution of the offenders. However, there had been delays in and difficulties with the proceedings because the courts were not convened frequently in those remote and sparsely populated areas. Ultimately, according to the consul, local authorities did not make any effort to stop the mob from attacking the Italian prisoners while en route to the jail, nor did the authorities try to prevent the mob from breaking into the jail. Hence, they must be held responsible for the actual lynching. ${ }^{44}$

Secretary of State Richard Olney (1895-1897) suggested to Ambassador Fava that he submit a claim requesting an indemnity for the victims' families, leaving it up to the President's benevolence to decide on the amount. Olney then transmitted Fava's request to President Glover Cleveland and stated that the facts were without dispute and that no comment or argument could add to the force of their appeal for the generous consideration of Congress. The only question, according to Olney, would be the amount of the gratuity, which must rest wholly in the discretion of Congress, "to whom it can hardly be necessary to cite the statutes of many states of the Union fixing the maximum to be enacted in the case of death caused by negligence at the sum of $\$ 5,000$." 45

President Cleveland, in a message to Congress on February 3, 1896, urged a reasonable pecuniary provision for the families of those who had been killed "without discussing the question of the liability of the United States for

\footnotetext{
${ }^{44}$ FRUS, 1895, 54th Cong., 2nd sess., 950.

${ }^{45}$ FRUS, 1895, 54th Cong., 2nd sess., 938.
} 
these results, either by reason of treaty obligations or under the general rules of international law." 46

Secretary of State Olney dealt also with the lynching of three Italians at Hahnville, Lousiana: Lorenzo Salardino, Salvatore Arena, and Giuseppe Venturella, who were held on a charge of homicide and were lynched in jail while they were still in custody of the local authorities. In his correspondence with Baron Fava, Olney stated that the lawless act was directed against the victims as criminals. The act was not due to racial prejudice, for three other Italians who were also kept in that jail were not harmed. ${ }^{47}$

In denying any responsibility by the federal government for the murders, Olney maintained that the three lynched men, by having taken part in political affairs and having voted in elections, must be considered as having renounced their legal status as subjects of the king of Italy. Salardino, Venturella, and Arena had lived in Louisiana for several years and had voted in elections. The crime of which they were accused was atrocious, and the attack on the jail was unexpected, but its success could not be attributed to any negligence or connivance on the part of the authorities. There was no reason to believe that the outcome would have been different had the three individuals been born on U.S. soil. According to Olney, they were not Italians temporarily residing in the United States, and although a declaration of intention had been found for only one of them, there were no doubts, Olney claimed, that the others had done likewise. Otherwise, they would not have voted at elections. By qualifying and acting as

\footnotetext{
${ }^{46}$ FRUS 1895, 1st sess., 938; H. Doc. 195, 54th Congress.

${ }^{47}$ FRUS 1896, 2nd sess., 407, 410, 411, Mr. Olney Secretary of State to Baron Fava, Italian Ambassador.
} 
voters, in accordance with the laws of the State of Louisiana, they had become citizens of that state, eligible even to hold office. Hence, under these circumstances, the U.S. government reserved its decisions as to whether the Italian government had "any right or duty of reclamation." ${ }^{48}$

Furthermore, Secretary of State Olney declared that, in securing an indemnity for injuries inflicted upon a citizen, the government that submits the claim is the citizen's agent. Olney contended that any legal defense that is good against the citizen himself is equally good against his representative. In Olney's view, any individual who had participated in electing officers and making laws must refrain from complaining about that government to another. "Although he may not approve of a particular act of that body, he contributes to the power which enables it to do any or all acts," he maintained. ${ }^{49}$

According to Olney, "the soundness of the position that an international reclamation will not lie against a government when the beneficiary of the claim by taking part in the organization and administration of that government has in effect given his assent to its proceedings, seems to be supported by every consideration of justice and equity." ${ }^{50}$ The wrongs done at Hahnville were to persons who had abandoned Italian soil and had ceased to be part of the Kingdom of Italy in that they had added nothing to its productive capacity or to its military strength. Hence, the prestige and power of the Italian government could

\footnotetext{
${ }^{48}$ FRUS 1896, 407, 410, 411, Mr Olney Secretary of State to Baron Fava, Italian Ambassador. See also Senate. Correspondence Regarding the Lynching of Certain Italian Subjects. 56th Cong., 1st sess., S. Doc. 171, Mr. Olney to Baron Fava, November 27, 1896.

${ }^{49}$ Senate. Correspondence Regarding the Lynching of Certain Italian Subjects, Ibid.

${ }^{50}$ Senate. Correspondence Regarding the Lynching of Certain Italian Subjects, Ibid.
} 
not be used on behalf of persons "whose fate and fortunes were at the time of the infliction of the wrongs complained of no real concern in that government." 51 In response, Baron Fava contended that the question at stake was the application of the fundamental principle of law and justice: that the persons accused were to be deemed innocent until found guilty by judicial process, and that the apparent criminality of the persons murdered was unimportant. He maintained that the evidence showed negligence on the part of the authorities in protecting the prisoners and in prosecuting the lynchers. Also such proceedings and failure to protect individuals while being held in custody could only encourage similar outrages in the future. Fava pointed out that naturalization could be granted only by federal law and that a mere declaration of intention did not confer citizenship. ${ }^{52}$ No matter what the laws of the State of Louisiana might be and although the lynched individuals might have voted in state elections, they were not citizens of the United States because they had not complied with the provisions required by federal laws concerning the process of naturalization.

Fava stated that, since the Italians had not complied with the requirements of the provisions on the subject of naturalization contained in the revised Statutes, they were still Italian subjects. $^{53}$

\footnotetext{
${ }^{51}$ Senate. Correspondence Regarding the Lynching of Certain Italian Subjects, Ibid.; FRUS 1896, 54th Cong., 2nd sess. 407, 410, 411.

${ }^{52}$ Senate. Correspondence Regarding the Lynching of Certain Italian Subjects, Ibid.; FRUS 1896, 54th Cong., 2nd sess., 412, 414, 418, 421, 422.

${ }^{53}$ Senate. Correspondence Regarding the Lynching of Certain Italian Subjects, Ibid.; FRUS, 1986, 54th Cong., 2nd sess., 412, 414.
} 
Baron Fava argued that the solution to the question could be found in the treaty in force between the United States and Italy. He again presented the request "that the guilty parties be sought and brought to justice; that steps must be taken to prevent the repetition of such atrocious crimes, and that just and adequate compensation must be made to the families of the victims." 54

As for Secretary of State Olney's contention that the Italian government could not consider as its subjects those Italians who voted in the states of the Union, Fava observed that the solution to this problem belonged solely to the Italian legislators and to Italian law. "As a matter of fact, I can add that the Federal government has always considered and still considers as citizens of the United States, the numerous Americans who in Hawaii take a prominent part in the political affairs, and vote openly at the elections of those islands." ${ }^{55}$

Olney, in his report to President William McKinley on December 7, 1896, stated that evidence gathered through an investigation showed that the three men lynched in Hahnville, Louisiana, had participated in the political affairs of this country and that their case was different from the previous episodes of New Orleans and Walsenburg for which indemnity was tendered to the relatives of the victims as loyal subjects to Italy. ${ }^{56}$ Olney said that, upon the assumption that the unfortunate men were, as in the case of some of the victims of the previous lynchings, Italian subjects, the government of Italy sought the mediation of the

\footnotetext{
${ }^{54}$ Senate. Correspondence Regarding the Lynching of Certain Italian Subjects, Ibid.

${ }^{55}$ Senate. Correspondence Regarding the Lynching of Certain Italian Subjects, Ibid.; FRUS 1896, 54th Cong., 2nd sess., 414-418; 421, 422.

${ }^{56}$ Annual Report of the Secretary of State, December 7, 1896, 54th Cong., 1897 HR Doc., LXXVI.
} 
United States with the Louisiana state authorities to investigate the occurrence and make provisions for the victims' families. The State of Louisiana promptly instituted an inquiry. Moreover, the Senate had appointed a trusted agent to conduct an independent investigation. Based on its results, it appeared that local authorities had taken all normal precautions for the safety of the prisoners and that they could not be blamed for the outbreak of mob violence against the three men accused of having murdered two esteemed citizens in the neighborhood. ${ }^{57}$

Olney added that whether any obligation rested upon the federal government under the circumstances--a matter that still remained to be ascertained--the existence or absence of such an obligation could not diminish the feelings of abhorrence with which all good citizens must view such brutal acts. ${ }^{58}$ The Hahnville controversy ended when Congress decided on an appropriation of $\$ 6,000$ that was made "out of humane consideration and without liability thereof, to the Italian Government, as full indemnity to the heirs of three of its subjects who were taken from jail and lynched in Louisiana in 1896." ${ }^{59}$

Likewise in the case of the lynching of five Italians at Tallulah, Louisiana (July 21, 1899), the main focus of the contention between Washington and the Italian representatives was whether the lynched individuals were Italian subjects or naturalized Americans. Count Vinci, chargé d'affairs in Washington, wrote to Secretary of State John Hay (1899-1901) about the event and demanded

\footnotetext{
${ }^{57}$ Ibid.

${ }^{58}$ Ibid.

${ }^{59}$ FRUS, 54th Cong., 2nd sess., HR Doc. 120, June 12, 1896, Mr. Olney to Baron Fava.
} 
protection for any Italian subjects that might be in danger in Tallulah. Secretary of State Hay telegraphed the Louisiana Governor, Murphy J. Foster, inquiring whether the persons lynched were "Italian subjects or naturalized Americans." ${ }^{60}$

On August 9, 1899, Alvey Adee, Acting Secretary of State, sent a reply to Count Vinci, stating that, based on evidence provided by Governor Murphy, the lynched individuals had been naturalized. Adee included copies of naturalization certificates from judicial records of the district court of Louisiana and the parish of Madison. ${ }^{61}$ However, the embassy made the point that, as the certificates of naturalization did not expressly state that the persons mentioned in them had previously made a declaration of intention, they must be considered only as first papers or, if intended as final papers, must be considered as irregular and void. ${ }^{62}$ The State Department, however, maintained that no recital of the declaration of intention was necessary and that the papers were not defective in form as certificates of naturalization. ${ }^{63}$

On September 20, 1899, the Department of State advised the Italian embassy that the grand jury had been unable to find an indictment on the facts before it, and that the matter would be submitted anew to the grand jury at the next term of court. As the report of the sheriff differed from the accounts

\footnotetext{
${ }^{60}$ FRUS, 56th Cong., 1st sess., 1899. Count Vinci to Mr. Hay; Mr. Hay to Governor Foster, 440.

${ }^{61}$ FRUS, 56th Cong., 1st sess., 1899. Adee to Count Vinci, 455.

${ }^{62}$ FRUS, 56th Cong., 1st sess., 1899. Count Vinci to Adee, August 20, 1899, 457.

${ }^{63}$ FRUS, 56th Cong., 1st sess., 1899. Hay to Count Vinci, September 1, 1899, 458.
} 
previously received, it was stated that a special agent would be sent to make the necessary investigations. ${ }^{64}$

As these episodes of violence had continued in the 1890s-- the lynchings of Italians in Walsenburg (1895), Hahnville (1896), and Tallulah (1899) -President William McKinley brought to Congress's attention the need for federal legislation concerning mob violence and the failure by the states to prevent it. In his annual message on December 5,1899 , he pointed out that, in spite of efforts by the federal government, the repeated inquests by the Louisiana grand jurors had failed to return indictments against the authors of the violence. President McKinley said, "I renew the urgent recommendation that I made last year that the Congress appropriately confer upon the federal courts' jurisdiction in this class of international cases where the ultimate responsibility of the federal government may be involved. I invite action upon the bills to accomplish this which were introduced in the Senate and the House. It is incumbent upon us to remedy the statutory omission which had led and may again lead to such untoward result. I have pointed out the necessity and precedent for legislation of this character. Its enactment is a simple measure of provisory justice toward the nations with which we as a sovereign make equal treaties requiring reciprocal observance." ${ }^{65}$ It is interesting to note that President McKinley's statement indicates that with respect

\footnotetext{
${ }^{64}$ FRUS, 56th Cong., 1st sess., 1899, Adee to Baron Fava, September 20, 1899, 463.

${ }^{65}$ FRUS 1900, XXII, President William McKinley, Annual Message, December 3, 1900; Moore, Digest of International Law, VI, 848.
} 
to the mob violence at Tallulah, Louisiana, there had been a denial of justice that could well be complained of by the Italian government. ${ }^{66}$

The subsequent investigation by the agent of the Department of Justice into the Tallulah lynchings revealed that, in reality, two of the lynched individuals had not been naturalized. Hence by the act of March 3, 1901, Congress appropriated the sum of $\$ 4,000$ to be paid "out of humane considerations, without reference to the liability thereof, to the Italian Government as full indemnity to the heirs of Joseph (Giuseppe) Difatta and John (Giovanni) Cirano, Italian citizens lynched at Tallulah, on July 20, 1899." ${ }^{67}$

When two Italian nationals were lynched at Erwin, Mississippi on July 10, 1901, the Italian ambassador in Washington, Francesco Carignani, submitted a similar claim to the one made to the State Department in 1891 by Ambassador Fava. The lynching in Erwin had been committed under the cover of darkness, and neither the coroner's inquest nor the investigation by the grand jury was able to discover the identity of the guilty parties. Once more the Italian government declared the lynching in Erwin, Mississippi and the failure of the local authorities to prosecute and punish the perpetrators to be a "denial of justice, a flagrant violation of contractual conventions, and a grave offense to every human and civil sentiment." 68

\footnotetext{
${ }^{66}$ Watson, “Need of Federal Legislation,” 577.

${ }^{67}$ FRUS, 56th Cong., 2nd sess., 1900, 715-731.

${ }^{68}$ FRUS, 57th Cong., 1st sess., 1901, 283, 285, 287, 289, 292, 293, 297-299.
} 
In his correspondence with Secretary of State John Hay, Carignani protested against the failure to bring the guilty parties to justice. The Italian ambassador described the U.S. failure to confer jurisdiction in such cases on the federal courts in order to make the federal government directly responsible (as recommended by President McKinley) as "a denial of justice, a flagrant violation of contractual conventions, and a grave offense to every human and civil sentiment." ${ }^{69}$ Until such power was conferred, the Italian government would have reason to complain of violation of the treaties and would not cease to denounce "the systematic impunity enjoyed by crime and to hold the federal government responsible thereof. ${ }^{70}$

The Department of State transmitted Carignani's protest to the Committees of the Senate and House of Representatives, which had under consideration the recommendation of the President that an indemnity should be tendered to the families of the victims and that legislation should be enacted conferring upon the federal courts original jurisdiction of offenses against aliens. The sum of $\$ 5,000$ was appropriated by Congress, using the usual formula, "out of humane consideration, without reference to the question of liability thereof to the Italian Government. ${ }^{71}$

In the Italian Parliament a heated debate occurred, with several deputies accusing the government of weakness and blaming it for accepting the "blood

\footnotetext{
${ }^{69}$ FRUS, 1901, 297-299; Moore, Digest of International Law, VI, 848-849.

${ }^{70}$ FRUS, 1901, Carignani to Mr. Hay, November 14, 1901, 297.

${ }^{71}$ FRUS 1901, Acting Secretary Hill to Ambassador Edmondo Mayor de Planches, January 2, 1902, 299.
} 
price." Deputies complained that, as in earlier cases, once more there was no attempt by the federal government to intervene and bring the assassins to justice. Such an attitude could only encourage Americans to continue with lynchings of foreign-born individuals as they could be sure to go unpunished. ${ }^{72}$ After Erwin, Ambassador Francesco Carignani proposed to Foreign Minister Luigi Prinetti not only to submit a formal protest to the federal government, but also to threaten that the treaty of 26 February 1871 would be considered null and void. ${ }^{73}$ However, there was no follow-up to Carignani's proposal. Instead, a more realistic attitude prevailed, leading to moderation, acceptance of an indemnity, and continuous effort to maintain good relations between Washington and Rome.

In spite of such efforts on the part of officials of both countries to maintain good relations, the question of the relationship between federal and state governments, the lack of federal jurisdiction in cases of mob violence against aliens, and the difficulties in conducting investigations after an episode of violence often caused embarrassment for both countries' representatives. Italian consuls indicated refusal to testify as the main factor in obstructing any attempt to bring the guilty parties to justice in cases of mob violence. For example, according to Consul Carlo Papini of New Orleans, "In general Italians are willing to testify in front of the Italian representatives. However, because of shyness, inconsistency, or external pressure, they completely alter their testimony or they

\footnotetext{
${ }^{72}$ ASDMAE, Italian Representative at Washington (1901-1929) pacco 147, pos. 3225. From MAE to Italian Embassy at Washington, 10 October 1901.

${ }^{73}$ ASDMAE, Ibid. From Italian Embassy at Washington to MAE, 10 October 1901.
} 
even deny it when testifying in front of the grand jury or in a court of law.. ${ }^{74}$ Nor were there any other means to obtain testimonies from Italians in the area, such as hiring a private detective or a secret agent. After the lynching at Erwin, Mississippi, in 1901, the embassy reported that "private agencies or secret police investigators refused to accept employment to conduct an inquiry. In fact, in the South a lynching is not considered a crime, and so investigators run the risk of being lynched themselves." 75

In only a few cases of mob violence in the United States where the person lynched was an alien were the state authorities able to secure indictments. In the words of President McKinley, "Local justice is too often helpless to punish the offenders.. ${ }^{76} \mathrm{Had}$ the federal government had power by virtue of a federal law to assume control in cases such as New Orleans, Walsenburg, Hahnville, Tallulah, Erwin, or Tampa, it could be assumed that convictions of the guilty parties might have been obtained. The court would have been free from any compulsion by friends in the community. An investigation could be conducted without fear of retaliation, a trial would be conducted in an orderly manner, witnesses would be properly protected, and the guilty or offending parties would be dealt with severely. In particular, the New Orleans case showed that a local grand jury was

\footnotetext{
${ }^{74}$ ASDMAE, Serie Politica "P” (1891-1916). From the Italian Consulate at New Orleans to MAE, 15 October 1901.

${ }^{75}$ ASDMAE, Diplomatic Representative at Washington (1901-1909), pacco 147, pos. 3225. From the Italian Embassy at Washington to MAE, 14 August 1901.

${ }^{76}$ FRUS, 56th Cong., 1st sess., XXII, President McKinley, Annual Message to Congress, December 5, 1899.
} 
unable to bring an indictment. ${ }^{77}$ If a federal court had had jurisdiction in that case, a federal grand jury would have conducted an investigation. The United States district attorney would have done his utmost to investigate and to bring the guilty parties to justice. The federal district attorney, like the judge of the court, would have been appointed by the President of the United States; therefore, his continuation in office would not have depended on the vote of the local community at an incoming election. He would have been free to perform his duties according to the Constitution and the laws of the United States. ${ }^{78}$

For over a decade, Congress's interest in the lynching problem focused mainly on the issue of protection of aliens in their treaty rights. For this purpose, bills were introduced in the Senate in 1893 and 1899 and in the House in 1900, $1902,1903,1905$, and $1907 .{ }^{79}$ In spite of frequent presidential recommendations, however, no action was taken until 1908.

On May 26, 1902, Senator Jacob Gallinger of New Hampshire (18911918) had introduced a resolution in regard to lynchings that directed the Judiciary Committee to investigate the subject of lynching and report whether there was any remedy for the evil. Gallinger said that lynchings had taken place in the North as well as in the South. He read a list of lynchings tabulated by states that showed only a few had taken place in northern states, while some southern states had long records in a single year. He also called attention to the

\footnotetext{
${ }^{77}$ Watson, “Need of Federal Legislation,” 568-569.

${ }^{78}$ Ibid., 568.

${ }^{79}$ Walter, “Legislative Notes and Review,” 437.
} 
fact that no lynchings had taken place in New England. In fact, the table that he submitted excluded the entire East and nearly all the West. ${ }^{80}$

Gallinger proposed that the Judiciary Committee should take the matter into consideration with a view to giving the country information on the numerous lynchings that had occurred. He said, "If we are powerless to do anything except under the operation of State laws, it is desirable that this fact should be made known to the public. I have been receiving letters on the subject ever since I entered the Senate, and it will be a relief to me personally, as I doubt not it will be to all Senators, to be able to answer these questions." ${ }^{81}$ Gallinger also said that the lynchings had increased in brutality as well as in number. A newspaper clipping of an account of a recent lynching and burning of a black man in Texas was sent to the desk to be read. Senator Gallinger stated that history did not furnish "a more fiendish instance of mob wrath and that Fox's Book of Martyrs was tame in comparison." ${ }^{82}$ Senator Gallinger wanted a resolution to be considered at once, but Senator Baley of Texas promptly reacted against it, saying that he was not going to be drawn into a sectional controversy. Although Gallinger denied any intention to provoke any such controversy, Bailey's objection prevented the consideration of the resolution that Gallinger had proposed. ${ }^{83}$ Senator Gallinger's resolution of 1902 for an investigation of lynching met the usual fate: it was laid on the table.

\footnotetext{
80 “To Investigate Lynchings,” The New York Times, May 27, 1902, 3.

${ }^{81}$ Ibid.

${ }^{82}$ Ibid.

${ }^{83}$ Ibid.
} 
In 1908, the House passed a bill recommended by the Department of State. It differed from the earlier bill in that it provided that "if two or more persons conspire to injure, oppress, threaten, or intimidate any alien in his free exercise of any right secured to him under any treaty of the United States, or because of his having so exercised the same, they shall be fined not more than $\$ 5,000$ or imprisoned not more than ten years, or both." ${ }^{84}$ The bill passed only by the deciding vote of the Speaker, even though less doubt of its constitutionality was expressed compared to the earlier bill of 1892. In the Senate, it was referred to the Committee on the Judiciary, and there it died. ${ }^{85}$ The proponents of the bill introduced similar measures in 1909, 1915, 1917, 1919, and 1920, but no action was taken.

Finally, the bill introduced by Representative Leonidas C. Dyer of Missouri in 1918 proposed to protect citizens of the United States against lynching in default of protection by the states; it also included a clause for the protection of aliens, adopting the form suggested in $1892 .^{86}$ Ever since the Dyer bill, the protection of aliens has been combined with general anti-lynching proposals. ${ }^{87}$

In its final form, the bill defined a mob as an assemblage of three or more persons acting in concert for the purpose of depriving any person of his life or doing him injury without authority of law, as a punishment for or to prevent some actual or supposed public offense. It declared that any state that failed,

\footnotetext{
${ }^{84}$ Cong. Rec., 60th Cong., 2nd sess., 1908, 43:166-175.

${ }^{85}$ Cong. Rec., 60th Cong., 2nd sess., 1908, 43: 254.

${ }^{86}$ Cong. Rec., 60th Cong., 2nd sess., 1908, 45: 1744.

${ }^{87}$ Walter, “Legislative Notes and Review,” 438.
} 
neglected, or refused to provide protection for any person within its jurisdiction against such a mob should be deemed to have denied to such a person the equal protection of the law. The bill further provided that any state or municipal officer who had the authority to protect such person and who failed, neglected, or refused to protect him or apprehend and prosecute those participating in such a mob should be guilty of a felony and so punished. Finally, the bill provided that those who had participated in lynchings might be tried in the federal district court according to the laws of the state; it made the county in which the person was lynched or in which he was seized liable to forfeit $\$ 10,000$ to be recovered by the United States through its courts for the use of the family or of the victim of mob action. The bill incorporated the provision regarding the treaty rights of aliens. ${ }^{88}$ Opposition to the Dyer bill was very strong, based on the grounds that it was unconstitutional. Opponents of the bill declared that it was an unconstitutional invasion of the reserved powers of the states guaranteed by the Fourteenth Amendment. Others, though, pointed out that, in a long line of cases involving the Fourteenth Amendment, the Supreme Court had held it to apply as a prohibition on state action, not on the action of individuals. Furthermore, when sheriffs acting as individuals failed to afford protection to prisoners, they violated duties imposed by state laws and so could not be considered agents of the state. Therefore, even though lynchings involved denying equal protection to the victims it was not the state that had acted. The states' failure to punish any crime

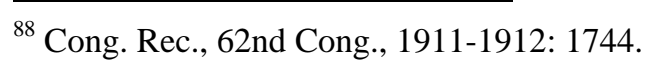


would amount to a denial of equal protection of the law, which was not the sense of the Fourteenth Amendment. ${ }^{89}$

Those in favor of the bill emphasized the necessity of federal legislation to punish the crime of lynching and pointed out how rarely any effective action was taken to punish lynchers. They stressed the urgency of such need and the necessity for the national government to make its resources available in order to prevent and punish mob violence. Emphasizing the barbarity of lynchings, their injustice, and the degradation of those who participate in such acts of violence, the proponents of the bill asked for its passage on humanitarian grounds and as a protection against mob rule and anarchy. ${ }^{90}$

On constitutional grounds, however, the supporters of the bill had more difficulty. They cited some of the same cases interpreting the Fourteenth Amendment to point out that a state may deny equal protection of the law by administrative and judicial acts as well as by legislation and that, when a state did so, the federal government may pass corrective legislation. They also claimed that the failure of a state to protect persons within its jurisdiction may be considered equal to a denial of protection. Furthermore, the failure of a sheriff to protect persons from mob violence, a violation of his statutory duties, was still to be considered the act of the state. Also the penalty on the county was a fine and not a tax, and so it was not forbidden by the rule regarding taxation of government instrumentalities. Since the United States may sue a state, it may

\footnotetext{
${ }^{89}$ Walter, "Legislative Notes and Review," 441.

${ }^{90}$ Ibid.
} 
sue a subdivision of a state and enforce upon it the jurisdiction of the federal courts. ${ }^{91}$

In 1922, after intense debate, the Dyer bill passed the House of Representatives by a vote of 231 to 119 opposed. Most of the opponents of the bill were Southern Democrats. Then the bill was withdrawn from consideration by the Senate, and it died. Since the failure of the Dyer bill, there have been other attempts to pass anti-lynching federal laws in Congress, but none have been successful. Measures introduced in the 1920s and in 1933 were referred to the Judiciary Committee in the House of Representatives and a measure introduced in the Senate in 1925 had a similar fate. ${ }^{92}$

Undoubtedly constitutional issues, states' rights, and sectional prejudices were serious obstacles to the enactment of a federal anti-lynching law. Indeed, states' rights was the main obstacle to passage of a federal anti-lynching law in cases of mob violence against native-born citizens. The matter became more complicated in cases of mob violence against aliens in that failure to protect aliens on U.S. soil may be considered a breach of treaties negotiated with foreign countries. The main objection raised to the enactment of federal law providing for the punishment of crimes against aliens in violation of the guarantees of treaties was that it granted to an alien a better right than it granted to a citizen of the United States. Such an objection was based upon the theory that when an alien received the protection of a state law, the same as a citizen, then the guarantee

\footnotetext{
${ }^{91}$ Ibid.

${ }^{92}$ Ibid., 442.
} 
of the treaty is fulfilled and there is no breach on the part of the federal government in respect to any rule of international law. This concept, however, is based on a false standard. In fact, it may very well be that the state law and the local tribunals enforcing the law may be adequate to protect a citizen fully and to ensure justice and yet be inadequate to protect and render justice in case of an alien. ${ }^{93}$

All the cases of lynchings of Italians in the United States that have been included in this study illustrate this concept. In each episode--and especially in the case of New Orleans in 1891--race feelings made it very difficult for the local authorities to be free from prejudice and accord the same degree of justice that was usually accorded to U.S. citizens. When authorities did not render to aliens the same degree of justice that was usually accorded to citizens, then it could be maintained that those who have been denied justice may demand an indemnity as compensation for the government's failure to meet international obligations to provide mutual protection. ${ }^{94}$

The whole question, then, was not simply one of the rights of citizens vs. aliens. When there was a failure to secure the same protection to the alien and the citizen, the question became one of international law on account of the failure of the government to fulfill a treaty obligation that guaranteed to an alien the same right of protection and the same degree of justice provided for a citizen. In cases of failure to provide such protection, the government could not shield itself

\footnotetext{
${ }^{93}$ Watson, “Need of Federal Legislation,” 579.

${ }^{94}$ Ibid., 579.
} 
from responsibility by claiming that the alien was awarded the same benefit of the local or state laws and also the right to trial in the same courts as a citizen. The government cannot do so because the standard of justice cannot be determined by one of the states of the Union. Rather, in legal theory, the standard is set by the family of nations. If any country's system of law does not conform to that standard, no other country can be compelled to accept it as a satisfactory measure of treatment of its citizens. ${ }^{95}$

In cases of mob violence against aliens the federal government at first took the position that there was no liability on its part; that protection to aliens residing within the states must be under the jurisdiction of local authorities; and that in paying indemnities for acts of mob violence, payment was made as an act of charity while liability was denied. This attitude placed the United States in an embarrassing position with Italian representatives who claimed that treaties mutually agreed upon were not respected and Italian nationals who worked and resided in the United States, in cases of mob violence, were not accorded the same protection and the same justice as native-born Americans. In 1891, however, the federal government changed its attitude. Since the New Orleans incident, the federal government no longer denied liability and, in cases where an indemnity was paid, such payment was made "without respect to the question of liability." This change of attitude could be interpreted as a realization that the 
federal government could no longer deny responsibility on account of a failure to enact legislation that would enable it to fulfill its treaty obligations. ${ }^{96}$

To a certain extent, the U.S. Constitution affords an alien a different degree of protection or the benefit of a different law than is accorded a citizen. In certain civil cases, the alien may resort to federal courts while the citizen is not granted that same privilege ${ }^{97}$ If that right is accorded in civil cases, it would seem logical to accord that same right in a criminal case and thereby to give the federal government the power to carry out its obligations. Proposals submitted to the U.S. Congress from 1892 to 1922 for a federal anti-lynching law, including provisions regarding protection of aliens from mob violence, originated from acknowledgment that, to a certain extent, it might be necessary to afford to an alien a different degree of protection than is accorded to a citizen. The episodes of mob violence and anti-Italian sentiment included in the present study illustrate the need for such an anti-lynching law, the inadequacy of local authorities to protect the alien while in custody, and the inability to secure convictions in a local court of law. The enactment of an anti-lynching federal law would have resulted in greater guarantees that alleged lynchers be brought to justice and would have placed the federal government in a better position to fulfill its international treaty obligations. ${ }^{98}$ However, racial prejudice, ethnic hatreds, and constitutional doubts

\footnotetext{
${ }^{96}$ Ibid., 581.

${ }^{97}$ See Constitution, Art.III, Section 2; see also Judiciary Act of 1789, Alien Tort Statute, U.S. Statutes at Large Rev. Statutes, sec 563 (1879) and Act of Mar 3d, 1911, ch. 231, clause 17 of sec. 563, 36 Stat. 1087, 1093.

${ }^{98}$ Watson, "Need of Federal Legislation,” 581. See also Nelson Gammans, "The Responsibility of the Federal Government for Violations of the Rights of Aliens,” The American Journal of International Law 8, 1 (January 1914): 73-80.
} 
could not be easily overcome and did not allow the enactment of a federal antilynching law.

Undoubtedly, of all Italian representatives who were involved in the contention between the United States and Italy concerning protection of Italian nationals on U.S. soil, Baron Fava was the most actively involved in efforts to solve the crisis and push toward passage of a federal anti-lynching law in order to fulfill treaty obligations of mutual protection. Once he returned to Italy, Fava, serving as Senator, continued indefatigably to be involved in cases of lynchings of Italians in the United States, addressing both legal and political aspects of the question. In 1902, during the controversy caused by the murders in Erwin, Mississippi, he wrote an essay in which he pointed out the constitutional issue as well as the legal aspects of the controversy, that is whether the Congress of the United States was able to "defer to federal courts cases of lynchings of foreignborn nationals and whether such federal courts existed in all the states of the Union." 99 Although American experts in jurisprudence argued that such federal courts did not exist, to counter such statements, Fava emphasized that the Supreme Court of the United States was located in Washington, D.C., and there were also nine federal courts, usually referred to as "circuit courts," whose judiciary powers extended to the whole territory of the United States. Each one of the circuit courts depended directly on one of the nine Supreme Court justices in Washington, D.C., with each one of them having jurisdiction over several states

\footnotetext{
${ }^{99}$ Francesco Saverio Fava, “I linciaggi negli Stati Uniti. La questione giuridica,” in Nuova Antologia vol. 97 (1902): 644-649.
} 
concerning illicit acts violating the laws of the federal Union. ${ }^{100}$ "As for the alleged impossibility by the U.S. Congress to defer to federal courts, established in the various states of the Union, jurisdiction over lynching of foreign-born, Fava maintained, it could be implied de facto.“101

With regard to the right of the U.S. Congress to defer such jurisdiction to the federal judiciary, Fava mentioned in the same essay that the issue was addressed by Senator Joseph B. Foraker, proponent of a bill "to provide for the punishment of violations of treaty rights of aliens." Foraker's report, submitted to the U.S. Senate on 14 February 1900, was unanimously approved by the senatorial committee, thus implying approval of de facto federal jurisdiction over lynchings of aliens. ${ }^{102}$

Fava also emphasized that Foraker's proposal had been prompted by Fava's own actions, persistence, integrity, and commitment to right wrongs. Fava stated that, in his appeal to the foreign minister on 20 December 1901, he reminded the Italian Senate that the proposed bill was the fruit of amicable negotiations that he had started back in 1899, soon after the lynching at Tallulah, Louisiana; such negotiations were conducted during the tenure of President McKinley, first, and then had been carried on by committee chairs in both Houses of Congress. ${ }^{103}$

\footnotetext{
${ }^{100}$ Ibid., 644.

${ }^{101}$ Ibid.

${ }^{102}$ Ibid., 645; Senate. Committee on Foreign Relations, Violations of Treaty Rights of Aliens, 56th Cong., 1st sess., 1900, S. Rep. 892.

${ }^{103}$ Ibid.
} 
Furthermore, Fava maintained that foreign treaties, once ratified by the U.S. Senate, became ipso iure laws of the federal Union. Fava continued by saying that a great number of American statesmen such as Webster, Evarts, and Blaine were definitely against any of the modifications of federal laws that the Italian government demanded. These American experts argued that protection of foreign-born nationals was based upon the doctrine of "the perfect equality of treatment of foreign-born and American-born citizens residing in the various States of the Union." However, Fava also pointed out that these American statesmen and legislators developed their thinking at a time when lynchings were not so common, that is before it became apparent that local prejudice totally nullified the role of the courts. After numerous cases of lynching remained unpunished and unresolved, it was clear that the federal government should take away from state courts the jurisdiction over cases of violence against aliens." 104 Fava praised the bill as a noble initiative that would legalize the concept that any crime committed in a State of the Union against a foreign-born must be considered a federal offense and therefore must be tried in a federal court of law rather than according to the law of that same state in which the crime had occurred. Such an achievement "would equally satisfy the local judicial rights of each State of the Union." ${ }^{105}$

Fava praised the bill proposed by Senator Foraker, arguing that it was drafted in a serious way, emphasizing those principles and concepts desired by

\footnotetext{
${ }^{104}$ Ibid.

${ }^{105}$ Ibid.
} 
the Italian government. Fava was optimistic that Congress would pass the bill. After all, the issue concerned not only the lynchings of Italians in America, but also violence and ethnic hatred against any aliens living and working in the United States. Hence, to assert and clarify the responsibility of the federal government in cases concerning foreign-born nationals in the United States ultimately would benefit all individuals of different ethnic backgrounds residing on U.S. soil. Eventually, they would be grateful to the Italian government that took the first step toward such long overdue reform. ${ }^{106}$

Fava was optimistic about the future. He wrote that a temporary halt to debate in the U.S. Congress over the proposal did not mean that eventually it would not be considered as the foundation of new negotiations, especially because of the recent events in Erwin, Mississippi. ${ }^{107}$ Fava concluded his essay by saying that no one else had done as much as he had to bring to the fore the issue that crimes against foreign-born should be under the jurisdiction of the federal government. He was confident that eventually the controversy would be solved in a satisfactory manner in the interest of both Italy and the United States. It would be beneficial to both countries that Italian nationals, who worked very hard with their own hands contributing to the wealth of the great republic of the United States, could obtain protection of their rights. ${ }^{108}$

\footnotetext{
${ }^{106}$ Ibid.

${ }^{107}$ Ibid., 649.

${ }^{108}$ Ibid.
} 
In spite of Fava's optimistic expectations, however, the enactment of a federal anti-lynching law could not occur, even though such a law would have placed the federal government in a better position to fulfill its international treaty obligations. Constitutional doubts, states' rights, and strong convictions that aliens who worked and resided in the United States were already guaranteed the same rights of protection and the same degree of justice provided for U.S. citizens could not be easily overcome in Congress. Yet, throughout the unfolding of the contention between Italy and the United States concerning protection of Italian nationals on U.S. soil, Italian diplomats and politicians adopted an attitude of prudence and moderation, and, with the exception of the New Orleans affair, they made efforts not to disrupt relations between the two countries. Despite the lack of basic human rights protection as required in international treaties, Italian governments continued to allow emigration to the United States. Such an attitude of prudence and moderation may have been prompted by an awareness of the relative powerlessness of the Italian government in moving the United States to protect immigrants from lynching as required in international treaties. Moreover, prudence, moderation, and acceptance of humiliating blood money demonstrate that Italian policymakers valued emigration to the United States both as a social "safety valve" and as a source of foreign currency and accumulation of capital. These two concerns were powerful enough incentives to keep emigration going, despite of the racism, discrimination, and violence that so many Italian nationals experienced in the United States. Italian governments protested vigorously and took blood money, but did not employ the ultimate sanction of cutting off the labor 
supply when the U.S. Congress failed to act. Besides respect for the great republic of the United States and acknowledgement of the relative powerlessness of the Italian government, the attitudes of prudence, moderation, and acceptance of the "blood price" demonstrate that Italian governments needed the emigration as much or even more than did American employers. 


\section{CHAPTER VII}

\section{CONCLUSION}

By the late 1800s, the United States was the great magnet for Italian emigrants. The United States represented the land of opportunities as well as the fragility of the American dream for Italian emigrants. In fact, Italian laborers were valued as industrious and reliable, but they were also stereotyped as subversives, anarchists, and trouble-makers. Although American employers valued Italian immigrants as a source of cheap labor, American workers resented them, as Italian workers were always willing to accept jobs for lower wages. Moreover, both American employers and workers looked down on Italian laborers as an inferior race. It is not surprising, then, that Italian immigrants were often subjected to discrimination, racism, and violence. In fact, numerous episodes of violence and even lynchings of Italians occurred in the United States in the late 1800 s and early 1900s--a period when strong, deep-seated anti-foreign sentiment pervaded American society. In most cases, the perpetrators of the violence were not found or brought to justice by the local authorities. Italian diplomats and politicians protested vigorously the failure of the U.S. government to protect Italian nationals residing and working on U.S. soil in accordance with their treaty rights. In general, however, Italian representatives chose a course of prudence and moderation and--except for the New Orleans lynching, which provoked a serious diplomatic crisis and national pride in the Italian Parliament, culminating in Rome's recall of its ambassador--they made efforts to maintain good relations between Rome and Washington. 
The inhabitants of the Italian peninsula and its nearest large islands have been one of the most migratory peoples on earth. From shortly after the completion of unification in 1871 until the onset of World War II, about twenty million people left Italy to find their livelihood elsewhere. Of these, almost half migrated to Europe, one-third went to South and North America, and smaller groups went to Australia and Africa. Italy was a poor and relatively overpopulated country, lacking sufficient resources for all its children, a fact that political unification could not change or quickly solve, despite rhetorical promises and the good intentions of Italian policy-makers. Individuals had moved frequently in the previous centuries, but the modern "great migration" assumed epic proportions. The post-unification exodus began as a temporary, seasonal migration to other regions of the Italian peninsula or other countries in Europe, but then it developed into a flood of Italian individuals leaving the homeland to find outlets in distant lands.

The magnitude of the migratory phenomenon engendered passionate debates in the Italian Parliament over the effects and consequences of the exodus on Italian society, economy, and politics. Should emigration be spontaneous, or should it be state-directed? This issue provoked a decadeslong debate between advocates of laissez-faire--that is, spontaneous emigration to the Americas--and proponents of imperialism to Africa. In Italy, members of government expressed contrasting opinions concerning emigration; however, whether optimistic toward emigration or opposed to it, with time the Italian ruling class acknowledged the need to regulate emigration and especially to protect the 
emigrant. Indeed, laws to protect the emigrant were needed as economic distress, agrarian crises, and heavy taxation prompted Italian laborers to leave the homeland and find work elsewhere.

The debate concerning emigration involved expressions of different political and economic ideologies present in Italy from the completion of the country's unification through the following decades. The development of opinion concerning the emigration question can be divided into three periods. During the first phase (1868-1888), in general politicians deplored emigration and sought to curb it. During the second phase (1888-1919), they deemed it a necessary evil, tried to look at its advantages as a safety valve, and sought to protect the emigrant. Finally, during the third phase (1919-1927), Italian policy-makers continued attempts to protect the emigrant and increased state control.

During the first phase, as early as in the 1860s, the debate focused on the deplorable aspects of emigration and described its evil consequences for Italian society and economy. During the 1880 s, however, official opposition to emigration subsided, and the debate shifted from whether it should be permitted to how it should be directed or regulated. Should there be laissez-faire, or should there be state control? Should Italians be allowed to establish free communities in the Americas, or should the government sponsor the settlement of colonies in Africa? Divisions ensued between those advocating peaceful establishment of free communities in the Americas and those who advocated imperial conquest in Africa. $^{1}$

\footnotetext{
${ }^{1}$ Ferdinando Manzotti. La polemica sull'emigrazione nell'Italia unita (1962; repr., Milan: Società Editrice Dante Alighieri,1969).
} 
The debate resulted in passage of the first important law regulating emigration on December 30, 1888, sponsored by Prime Minister Francesco Crispi. The 1888 law aimed at ensuring public order and regulating the activities of shipping companies, agents, and subagents, all of whom had to obtain licenses from the Ministry of the Interior in order to operate. It gave Italian authorities the ability to control emigration in order to suppress illegal activities. Crispi's law was the first step toward acknowledgement that the government should be responsible for the emigrant. However, it was unclear whether the promoter of the law deemed emigration good or evil for Italian society. ${ }^{2}$ In addition, as the emigrants' remittances were dispatched back to Italy, it became apparent that the emigrants' sacrifices and savings were beneficial for the Italian economy, and thus, defense of emigration became popular. ${ }^{3}$

During the second phase of the political debate over emigration (18881919), a true landmark in Italian emigration policy was the Law of 1901, passed during the tenure of Prime Minister Giovanni Giolitti. The 1901 law was based on the principle that the emigrant is a citizen and must be protected by the government. The law presumed that the emigrants, by the very fact of their social condition and character, could fall easy prey to agents, subagents, and recruiters. Emigrants were shy, ignorant, and credulous and could easily be defrauded and cheated. However, they were citizens and, as citizens, they deserved the government's protection. The law transferred responsibility for the

\footnotetext{
${ }^{2}$ Manzotti, La polemica sull'emigrazione, 82-83.

${ }^{3}$ Robert Foerster, The Italian Emigration of Our Times. (1919; repr., Cambridge: Harvard University Press, 1924), 477.
} 
emigrants from the jurisdiction of the Ministry of Interior to the Foreign Ministry. To the Minister of Foreign Affairs, the law gave power to suspend emigration to any place where life, liberty, and property of the emigrants might be at risk. ${ }^{4}$

The most distinctive creation of the law was the Office of the Commissioner General of Emigration (CGE), reporting to the Ministry of Foreign Affairs. The Commissioner General was a member of the Emigration Council, a broadly representative body of twelve individuals who met at least twice a year to discuss questions concerning all matters of interest for the well being of the emigrant. The law required every carrier to pay a tax of eight lira on every ticket sold; this tax and all license fees were credited to an Emigration Fund that was established for the benefit of the emigrant and administered by a Parliamentary Committee. No expenditure was allowed from this fund unless clearly for the exclusive advantage of the emigrant. ${ }^{5}$ In matters concerning emigration, not only was the commissioner a focal point for all public protective institutions, but he also had an important relationship with private institutions. Through publication of the Bollettino dell' Emigrazione, the CGE offered useful information for the emigrant and anyone involved with emigration.

In general, scholars of Italian emigration history have praised the 1901 law as an epoch-making law and a true milestone in the development of government policy aimed at protecting the emigrant from cruel exploitation by profiteers. The law signaled the beginning of a more dynamic phase in Italian emigration policy

\footnotetext{
${ }^{4}$ Foerster, The Italian Emigration of Our Times, 478.

${ }^{5}$ Ibid., 479.
} 
and, although it was modified over the years, its fundamental structure and the principles upon which it had been established remained unaltered. ${ }^{6}$

One important final revision of the 1901 law occurred after World War I with passage of a comprehensive law aimed at reorganizing all existing laws regarding emigration. The reason for passage of this comprehensive law, or Testo Unico, was that the role of the office of the CGE had expanded during wartime beyond its original competencies. It became responsible for assisting emigrants who wanted to return home to enlist in the Italian army, for taking care of mobilization, for maintaining relations with Italian consulates abroad, and for providing necessary documentation to the police for the issuing of passports. ${ }^{7}$

The third phase of Italian emigration policy (1919-1927) covered the period from the aftermath of World War I through the initial stage of the establishment of the fascist dictatorship in Italy. The rise of Benito Mussolini to power brought changes to Italy and to official emigration policy based on fascist ideology and the regime's tendency to regulate and control all aspects of life. Mussolini claimed that Italy was a country of super-abundant energy and chose to call emigrants "Italians abroad." He emphasized the need to control the emigration flux and especially to make emigration temporary and not permanent. He also wanted to project a positive image of Italy and Italians abroad, to raise the general esteem of Italian workers abroad, as well as to enhance the value of

\footnotetext{
${ }^{6}$ Foerster, Italian Emigration of Our Times, 477; Dore, La democrazia italiana, 107; Rosoli, Un secolo di emigrazione italiana, 258; Manzotti, La polemica sull'emigrazione, 156-157.

${ }^{7}$ Sori, L'emigrazione italiana, 401-403.
} 
Italiannes, Italian culture, traditions, and values. ${ }^{8}$ Hence, Mussolini made several changes in the government's emigration policy. One important initial step was abolishing the CGE and replacing it with the General Bureau of Italians Abroad, a more political organ that could be better controlled as well as more easily linked with the Fasci all'Estero (Fascist clubs abroad), a network of fascist clubs outside of Italy that provided assistance to Italian nationals abroad. At the same time, a consular network was increased with the infusion of men faithful to the regime. ${ }^{9}$

Mussolini hoped to spread fascist ideology and, at the same time, to improve the image of Italians abroad through this network of fascist clubs and consulates. Besides establishing Fasci in Europe, the fascist regime looked at North America, with its large Italian community, as fertile soil for the preservation of italianità as well as for the spread of fascism. Fascist clubs sprang up in America; at the same time, old Italo-American societies were transformed into Fasci shortly after Mussolini's rise to power. The United States was given prime attention in this goal of preserving Italian culture as well as in spreading fascist doctrine. ${ }^{10}$

Mussolini's vision of emigration and emigrants clashed with the growing protectionist and anti-immigration legislation being enacted in many countries. Among them was the United States, which in 1921 and 1924 enacted laws that established a quota system and effectively closed its borders to many emigrants.

\footnotetext{
${ }^{8}$ Philip Cannistraro and Gianfausto Rosoli, "Fascist Emigration Policy in the 1920s: An Interpretative Framework,” International Migration Review, vol. 13, no.4 (1979): 673-692.

${ }^{9}$ Ibid., 678-679.

${ }^{10}$ Alan Cassels, Mussolini’s Early Diplomacy (Princeton: Princeton University Press, 1970), 195-196.
} 
The Immigration Act of 1921 and the Johnson Act of 1924 curtailed immigration from southern and eastern Europe--the so-called "new immigration." Fearful nativists pointed to the new arrivals' degenerate character, racial characteristics, and innate tendencies toward crime.

The legislation of the 1920s was the result of decades-long, deeply rooted anti-immigrant sentiment accompanied by a resurgence of nativism. Anti-Italian sentiment was particularly strong for though Italians were viewed as industrious, hard-working individuals, they were also seen as dangerous subversives who were often prone to trouble-making. This contradictory image of the Italian immigrant rooted in both deep racism and economic conflict produced numerous lynchings in the late nineteenth and early twentieth centuries. In most cases, the guilty parties were never found and the violence went unpunished by the local authorities.

Anti-immigrant sentiment always filtered through a specific ethnic stereotype when Italians were involved, for in American eyes, they always bore the mark of Cain. They suggested the Mafia, the stiletto, the deed of impassioned violence. In fact, every time a single Italian laborer resorted to his knife, the American press emphasized the disposition to assassinate as an innate characteristic of this impulsive race. The stereotype conditioned every major outburst of anti-Italian sentiment in the late 1800 s and early 1900 s. $^{11}$

Time and time again, lynch mobs struck at Italians charged with murder or suspected of being likely to commit murder. Economic competition, too, was

\footnotetext{
11 John Higham, Strangers in the Land: Patterns of American Nativism, 1860-1925 (1955; repr., New Brunswick: Rutgers University Press, 1998), 90.
} 
often a major cause of outbreaks of racial violence. The numerous episodes of lynching individuals of Italian origin that occurred during the 1890s and early 1900s strained relations between Italy and the United States. In fact, relations between the two countries became more and more difficult, opening the way to various and complex diplomatic incidents. In particular, the 1891 lynching at New Orleans signaled the beginning of a period of strife between Italy and the United States. The New Orleans lynching was not an isolated event. It had been preceded by other episodes of racial violence in small towns such as Eureka, Nevada; Vicksburg, Mississippi; and Louisville, Kentucky. However, the episode at New Orleans was a ferocious example of anti-Italian sentiment and racism; consequently, by the 1890s, U.S. and Italian relations had become contentious and explosive.

The city of New Orleans was a haven for a large migratory population from southern Italy. The city experienced the social problems of the urban North colored by Southern folkways. When the chief of police was murdered, everybody blamed the local Italian Mafia; over a hundred Italians were arrested in an atmosphere of hysteria and taken to jail. Mayor Joseph Shakspeare issued a public appeal to teach the Italians a lesson that they would not forget. The city council appointed a citizens' committee to suggest ways to deal with European criminals and prevent them from immigrating into the city.

When some of the accused were tried, the allegedly bribed jury stunned the city by refusing to convict. While officials stood idly by, a mob proceeded to remedy the perceived failure of justice by lynching eleven Italians who had been 
acquitted just the day before. The lynching mob was made up of top members of the city's press, political, and business establishments. In the aftermath of the lynchings, many of those who were members of the execution squad profited. The victims had established themselves as rising businessmen along the docks. After the lynching, those who had cried Mafia became wealthy by replacing the Italian- American businessmen in the port city of New Orleans. Throughout the country, their actions were generally condoned or even approved. Clearly, both ethnic hatred and economic competition had played a major role in the unfolding of the violence. ${ }^{12}$

The Italian government asked for official reassurance from the United States not only that the guilty parties would be brought to justice, but also that it would recognize the principle that an indemnity was due to the relatives of the victims. The federal government took the position that if, after proper investigation, a case was established for relief to be granted to the families of the Italian subjects who had lost their lives by lawless violence, it would be submitted for the consideration of Congress.

Throughout the diplomatic controversy engendered by the New Orleans lynching, the U.S. government claimed that there was no liability on its part for acts of mob violence, that protection of aliens residing and working in the United States must be under the jurisdiction of local authorities, and that criminal prosecution for any acts of mob violence must also rest with the state authorities. However, after the New Orleans incident, it was clear that the Louisiana

\footnotetext{
${ }^{12}$ Higham, Strangers in the Land, 91.
} 
authorities had been unable to extend sufficient protection to the Italians while in custody.

The main outcome of the New Orleans episode was the beginning of a movement in Congress for passage of a much-needed federal anti-lynching law to transfer jurisdiction to the federal courts in cases of mob violence. A bill was introduced in the Senate on March 1, 1892, proposing that, where acts that were crimes under the laws of the states were committed against aliens in violation of their treaty rights, the offenders should be prosecuted in the federal courts. Heated debates in both houses followed. However, interest in the bill died, and it never came to a vote.

For over a decade, the interest that Congress had in the lynching problem focused on the issue of protecting treaty rights of aliens. However, in spite of frequent presidential recommendations, not one proposal for a federal antilynching law introduced in the Senate or House succeeded. In 1902, a resolution proposed by Senator Jacob Gallinger of New Hampshire would have directed the Senate Judiciary Committee to investigate lynchings and report whether there was any remedy for the evil. It was tabled. In 1908, the House passed a bill recommended by the State Department. However, in the Senate, it was referred to the Judiciary Committee, where it died.

An important step forward was made by Representative Leonidas C. Dyer of Missouri in 1918; he proposed a bill to protect citizens of the United States against lynching in default of protection by the states. The bill also included a clause for the protection of aliens, adopting the form suggested in 1892. The 
Dyer bill failed to pass in Congress. From that time forward, though, the problem of protecting aliens would be combined with general anti-lynching proposals. Although such laws would have benefited all minorities and ethnic groups in the United States, successive attempts in the 1920 s and 1930 s to pass muchneeded federal anti-lynching measures failed to pass in Congress because of constitutional issues, states' rights, and sectional prejudices.

Undoubtedly, states' rights was the most serious obstacle to the enactment of a federal anti-lynching law. The matter became even more complex in cases of mob violence against aliens. In fact, the main objection in Congress to passage of a federal anti-lynching law conferring jurisdiction on the federal courts and providing for punishment of perpetrators of crimes against aliens in violation of international treaties was that such law would grant an alien more extensive rights than those awarded a citizen. Yet, as most episodes of violence included in this study illustrate, the federal government was often in an embarrassing position because, time after time, cases of violence against Italian nationals showed that state laws and local authorities were not able to afford aliens the same protection that was extended to native-born citizens. The government could not claim that citizens and aliens were awarded the same protection of the law, the same benefits, and the same rights under the laws of the states in which they resided. Racial animosity made it very difficult for the local authorities to be free from prejudice and to grant the same degree of justice allowed to a native-born citizen. In cases of failure to secure the same protection to the alien and to the citizen, then the question became one of international law 
based on the failure by the government to fulfill its international treaties obligations.

The episodes of mob violence included in this study illustrate that there was a need for an anti-lynching law, and that local authorities were unable to protect an alien while in custody, or to secure convictions in local courts of law. The enactment of a federal anti-lynching law would have resulted in a greater likelihood that alleged lynchers would be punished for their crimes and would have placed the federal government in a better position to fulfill its treaty obligations. The federal government always claimed that there was no liability on its part for acts of mob violence and that protection of aliens must rest with state authorities. Contradictorily, it always granted indemnities to the victims' families. Although the indemnities were awarded "out of humane considerations and without liability thereof," it could be argued that the government's payment of indemnities implied admission of failure to comply with existing treaties obligations.

In Italy, from the liberal government to the fascist government, Italian policy-makers succeeded in regulating emigration, enacting laws to protect the emigrant from cruel exploitation by profiteers, and acknowledging the Italian government's responsibility to protect the emigrant. However, neither the liberal nor the fascist governments succeeded in affording protection to the emigrant abroad.

Did relations between Italy and the United States change because of the episodes of mob violence and anti-Italian sentiment in the late 1800s and early 
1900s? An analysis of available documents reveals that, in general, Italian diplomats serving in the United States from the 1870 s to the 1920 s tried to maintain good relations between Rome and Washington. Even in the one exception, when the facts of New Orleans culminated in Rome's recalling its ambassador, Baron Fava, one could argue that the Italian government tried to maintain a course of prudence and moderation. In fact, after payment of indemnities to the victims' families, relations were restored and Fava returned to the United States.

How did relations between Italy and the United States change after the rise of the Fascist dictatorship in Italy? Undoubtedly, Mussolini brought changes to Italy as well as to Italian domestic, foreign, and emigration policies. These changes were consistent with the regime's ideology, its tendency to centralize control, and the Duce's claim that Italy was a country of superabundant energy rather than a country whose citizens were forced to leave because of a lack of sufficient resources. ${ }^{13}$

One important change in Mussolini's foreign policy was the initiative to spread fascist ideology as well as Italian culture through a network of fascist clubs both in Europe and in the United States. Because of the large Italian community that had settled in North America, Mussolini and his associates looked at the United States as an ideal environment to preserve Italiannes, to spread fascist ideology, and to better the overall image of Italy in both the Italian and American communities. Hence, the United States was given primary

\footnotetext{
${ }^{13}$ Philip Cannistraro and Gianfausto Rosoli, "Fascist Emigration Policy in the 1920s: An Interpretative Framework.” International Migration Review, vol. 13, no. 4 (1979): 673-692.
} 
attention as fertile soil for the implementation of Mussolini's main goals in foreign policy. Mussolini largely ignored Italian diplomats of the fascist era such as Ambassador Gelasio Caetani, who advised him to be cautious and warned him that attempts to spread fascist ideology would hurt rather than help the Italian image in America. ${ }^{14}$

Italian Fascism in the United States made serious attempts to increase its political influence and resorted to subversive political activities to expand Blackshirt influence. At the same time, Italian-American Fascists attempted to attract to Mussolini ordinary Italian Americans who supported the United States, but who also championed fascist Italy in any matters that would not clash with allegiance to the United States. Fascist Italy considered the support of Italian American lobbyists to be essential in gaining Washington's approval for Rome's foreign policy.

Eventually, Mussolini's "March on America" failed when the Blackshirt leadership found that the political strength of the United States was formidable and that the majority of Americans, including Italian Americans, resisted efforts by the Blackshirts to advance their ideas and organization. Moreover, efforts by Blackshirt leaders in America to create a movement failed because their political ideas differed little from traditional American beliefs. Italian Fascism in the United States appeared as a "junior partner" of Americanism rather than a clear political alternative. Italian American fascism evidences a serious but failed attempt by a

\footnotetext{
${ }^{14}$ Alan Cassels, Mussolini’s Early Diplomacy (Princeton: Princeton University Press, 1970).
} 
foreign power to subvert the loyalty of American citizens. ${ }^{15}$ In fact, rather than succeeding in protecting the emigrants, Mussolini sought to exploit them and thereby put them at greater risk of violence and reprisals. The Fascist clubs were essentially political exploitation of a valuable minority population.

While attempting to spread fascism, to preserve Italiannes, as well as to disrupt Italian Americans' allegiance to the United States, the fascist government strove to maintain as many legal and political ties as possible with Italian emigrants. The regime insisted that emigration must be temporary and not permanent. It also insisted on the emigrant's obligation to do military service in Italy. For the Fascist regime, the Fasci abroad were an integral part of its emigration policy. Yet, in spite of good intentions, nationalistic fervor, and bombastic rhetoric, the problem of protecting Italian nationals abroad remained unresolved.

During the fascist era, Italian representatives in the United States did not have to deal with any lynchings of Italian nationals. However, they did have to deal with restrictive immigration laws enacted in the1920s to curtail the immigrant influx into the United States, laws that were deemed discriminatory and unfair. The Fascist government could do little except protest the laws. For example, on January 24, 1922, Italian Ambassador Rolando Ricci wrote a letter to Secretary of State Charles Evans Hughes (1921-1923). In it, Ricci observed that, since the results of the 1920 census had already been published, the establishment of quotas based on the 1910 census would openly discriminate against peoples of

\footnotetext{
${ }^{15}$ Martin Scott Catino, "Mussolini’s March on America: Italian Americans and the Fascist Experience, 1922-1941” (PhD Dissertation, The University of Southern Mississippi, 2003).
} 
different nationalities, a course that would violate existing treaties providing "equality of rights and of treatment." 16

Furthermore, Ambassador Ricci pointed out that Italy would be particularly affected by such decision of Congress, as its greatest flood of emigration to the United States occurred between 1910 and 1914. Ricci also suggested that passports should be the only element for determining the nationality of aliens and their assignment to a quota, that is, the quota of the nation that had granted the passport. (In one incident, Italian citizens of Rhodes were denied entrance to the United States because they had been assigned to the exhausted quota of Greece). Making passports the only basis upon which to assign quotas, Ricci maintained, would avoid confusion, discrimination, and unnecessary hardships. Such a system would be legal, sound, and politically indisputable. Moreover, according to Ricci, the passport requirement would permit a nation to take responsibility for strict adherence to its quota and to protect its own citizens while observing American law. ${ }^{17}$

On May 18,1922 , Secretary of State Hughes wrote to Ricci that the Immigration Act of 1921 did not violate the treaty of 1871, nor did restrictions appear to be discriminatory against Italy or any other country. ${ }^{18}$ Hughes stated that restrictions imposed by the law were of a general character. Hughes added that copies of Ricci's notes would be sent to the Chairman of the Committee on

\footnotetext{
${ }^{16}$ FRUS, 1922, Ambassador Ricci to Secretary of State Hughes, Washington, 24 January, 1922, 579.

${ }^{17}$ Ibid., 580.

${ }^{18}$ Ibid. Secretary of State Hughes to Ambassador Ricci, 585.
} 
Immigration of the United States Senate and the Chairman of the Committee on Immigration and Naturalization of the United States House of Representatives. ${ }^{19}$ Needless to say, the Italian protest about immigration restrictions did not result in any changes of the law. It must be observed that, in this attempt to obtain changes in U.S. immigration laws, Mussolini was as impotent as the liberals who preceded him.

However, as immigration to the United States subsided, so did antiimmigrant feelings, xenophobia, and violence against aliens. Lynchings of Italians in the United States had been a manifestation of anti-immigrant sentiment deeply rooted in racism during a time when southern and eastern Europeans were considered a menace to American society. Lynching was a tool to maintain control over the labor force and to ensure the prestige and supremacy of the native-born over the foreign-born, who were frightening with their strange ways, traditions, habits, religions, and cultures. Moreover the Italians' whiteness was often called into question; their "in-between-ness" was often considered a disturbing factor disruptive to the order of things. Hence, mob violence against Italians may be seen as an attempt to protect society from an "inassimilable" group that constituted a threat to white racial unity.

In recent years, scholars have produced numerous important studies on white mob violence against African Americans. Historians, sociologists, and literary critics have proposed a host of explanations for the widespread brutality that resulted in the deaths of thousands of individuals in the South, West, and

\footnotetext{
${ }^{19}$ FRUS, 1922, Secretary of State Hughes to Ambassador Ricci, 18 May 1922, 582.
} 
Midwest between 1880 and 1930. No single explanation has dominated. Lynching was about economics; it was about racism; it was about ethnic hatred, social repercussions, cultural meanings, and preservation of the order of things.

The lynching of white ethnics, nonetheless, remains a relatively neglected subject. Although a minor phenomenon in comparison to black suffering, the stories of the lynching of Italians in the United States need to be told. The brutal shooting of the charcoal burners in Eureka, Nevada; the Villarosa hanging in Vicksburg, Mississippi; the lynching of the Cravassos brothers in Kentucky; the ferocious lynching of the eleven Italians in New Orleans; the episode of Walsenburg, Colorado; the lynching of Salardino, Arena, and Venturella in Hahnville, Louisiana; the lynching of the Difattas in Tallulah; the brutal shooting of the Serios in Erwin, Mississippi; and the gruesome hanging of Ficarotta and Albano in Tampa, Florida--all are emblematic of the racism and discrimination that Italians endured in the late 1800 s and early 1900 s. These men were strangers in the land who were pursuing the American dream but who found violent deaths in the supposed land of opportunity. These stories represent a chapter in the history of Italian Americans that has largely been ignored.

The movement that started in the U.S. Congress for passage of a muchneeded federal anti-lynching law to protect aliens from mob violence may very well be considered the beginning of the civil rights movement in the United States. Moreover, since protection of the treaty rights of aliens was involved, that movement may also be seen as an initial step toward consideration of protection of aliens in foreign countries in international law. 
However, all these episodes illustrate the relative powerlessness of the Italian government to extract vigorous enforcement of agreed-upon protection for aliens in international treaties. In the end, Italian governments--from the liberals through the fascists--though they failed to obtain real federal protection for their citizens, persisted in allowing emigration to the United States. This pragmatism says something important about the value that Italy placed on the continued emigration to the United States. The emigrant children of Italy were valued as a social "safety valve" and as a source of capital accumulation through their savings sent home. Those advantages overpowered concerns for human rights in the calculation of Italian policy. Italian emigrants were put at risk.

Even in the absence of adequate anti-lynching laws, not only did the liberal governments decline to cut off emigration, but Mussolini's government objected to American-imposed quotas and restrictions. The liberal governments protested the racism, discrimination, and violence, but accepted humiliating indemnities for the victims' families. The governments chose not to employ the ultimate sanction of cutting off the labor supply. Moreover, despite the bluster of the Mussolini era, the Fascists were no more able to affect U.S. law than were their predecessors. In fact, Mussolini's promotion of Fascism put Italian emigrants at greater risk of violence and retribution in the absence of federal antilynching laws. Still further, Mussolini so desired the emigration to continue that he protested restrictive U.S. immigration quotas even though there had been no progress in protecting Italian nationals from discrimination. 
Although Italian policymakers protested vigorously the lack of protection or unfair quotas--and even recalled the Italian ambassador after the New Orleans incident in an upsurge of nationalistic fervor--in the end they accepted humiliation and even violence as the fate of many of their citizens and as a necessary sacrifice to keep Italian economic matters from becoming worse. Ultimately, from the liberals to the Fascists, Italian officialdom, in continuing the migration trade, chose prudence, moderation, and pragmatism over the human rights of Italian emigrants. 
BIBLIOGRAPHY

ARCHIVAL SOURCES

ITALY

ARCHIVIO STORICO DIPLOMATICO MINISTERO DEGLI AFFARI ESTERI (ASDMAE), Rome.

ASDMAE, Fondo Archivistico serie "P" U.S.A. (1891-1916); Serial File nos. $357 ; 445 ; 591 ; 603 ; 605 ; 623 ; 656 ; 680 ; 682 ; 683$.

ASDMAE, Fondo Archivistico serie "Z" "Contenzioso" (1891-1910), Serial File nos. 33, 35, 59.

ASDMAE, Fondo Archivistico Italian Diplomatic Representative at Washington (1848-1901), File no. 150; (1901-1909), File nos.103; 147.

ASDMAE. Trattati e Convenzioni fra il Regno d'Italia e I governi esteri. Vol. IV (1870-1873), Rome: Barbera, 1874.

Atti Parlamentari, Camera dei Deputati, Vol. 8, 1903.

Atti Parlamentari, Senato del Regno, Legislature XXI, 1901.

Ministero degli Affari Esteri (MAE). Notizie statistiche sull'emigrazione italiana all'estero dal 1869 al 1976, in Annuario Statistico dell'Emigrazione Italiana. Commissioner General of Emigration. Rome: CGE, 1926.

Ministero degli Affari Esteri (MAE). Commissioner General of Emigration. Emigrazione e Colonie. Raccolta di rapporti dei RR agenti diplomatici e consolari: America. 4 vols. Rome: CGE, 1903-1908.

Ministero degli Affari Esteri (MAE). Commissioner General of Emigration, Bollettino dell'Emigrazione. Rome: Tipografia Nazionale di Giovanni Bertero (1904; 1908; 1909; 1910; 1913; 1924; 1926).

Ministero degli Affari Esteri (MAE). "Relazione per l'anno 1909-1910, submitted to the Foreign Ministry by the Commissioner General of Emigration Luigi Rossi." Rome: CGE, 1910.

Ministero degli Affari Esteri (MAE). "La conferenza internazionale dell'emigrazione e dell'immigrazione Rome, March 15-31, 1924." Rome: CGE, 1924. 


\section{UNITED STATES}

United States Department of State. The Executive Documents of the House of Representatives for the First Session of the Fifty-Second Congress: Washington, DC: Government Printing Office, 1891-1892.

United States Department of State. Papers Relating to the Foreign Relations of the United States, with the Annual Message of the President, Transmitted to Congress December 2, 1895: Washington, DC: Government Printing Office, 1895.

United States Department of State. Papers Relating to the Foreign Relations of the United States, with the Annual Message of the President Transmitted to Congress December 7, 1896, and the Annual Report of the Secretary of State: Washington, DC: Government Printing Office, 1896.

United States Department of State. Papers Relating to the Foreign Relations of the United States, with the Annual Message of the President Transmitted to Congress December 5, 1899. Washington, D.C.: Government Printing Office, 1899.

United States Department of State. Papers Relating to the Foreign Relations of the United States, with the Annual Message of the President Transmitted to Congress. Washington, DC: Government Printing Office, 1901.

United States Department of State. Papers Relating to the Foreign Relations of the United States, with the Annual Message of the President Transmitted to Congress December 2, 1902. Washington, DC: U.S. Government Printing Office, 1902.

United States Department of State. Papers Relating to the Foreign Relations of the United States with the Address of the President to Congress December 2, 1913. Washington, DC: Government Printing Office, 1913.

United States Department of State. Papers Relating to the Foreign Relations of the United States, 1922. Washington, DC: U.S. Government Printing Office, 1922.

United States Department of State. Papers Relating to the Foreign Relations of the United States,1925. Washington, DC: U.S. Government Printing Office, 1925. 
United States Department of State. Papers Relating to the Foreign Relations of the United States, 1926. Washington, DC: U.S. Government Printing Office, 1926.

United States Department of State. Papers Relating to the Foreign Relations of the United States, 1927. Washington, DC: U.S. Government Printing Office, 1927.

United States Department of State. Papers Relating to the Foreign Relations of the United States, 1928. Washington, DC: U.S. Government Printing Office, 1928.

U.S. Congress. Senate. Correspondence Regarding the Lynching of Certain Italian Subjects. 56th Cong., 1st sess.,1897. S. Doc.104. Washington, DC: Government Printing Office, 1987.

U.S. Congress. Senate. Violations of Treaty Rights of Aliens. Report of Senator Foraker of Ohio from the Committee on Foreign Relations. 56th Cong., 1st sess.1900.S. Doc. 892. Washington, DC: Government Printing Office, 1900.

United States - Italy, Treaty of Commerce and Navigation (February 26, 1871) in Malloy's Treaties, 1:969.

Moore, John Bassett. Digest of International Law. Washington, D.C.: Government Printing Office, 1906.

\section{SPECIAL WORKS}

Allen, James Paul. We the People: An Atlas of America's Ethnic Diversity, New York: Macmillan, 1990.

Allen, James, et al. Without Sanctuary. Lynching Photography in America. Santa Fe, NM: Twin Palms Publisher, 2000.

Chi e'? Dizionario degli Italiani di oggi. Rome: Cenacolo, 1940.

Holte, James Craig. The Ethnic I: A Sourcebook for Ethnic-American Biography. Santa Barbara, CA: Greenwood Press, 1988.

Pozzetta, George E., ed. American Immigration and Ethnic History. New York.: Routledge, 1991.

Thernstrom, Stephan, ed. Harvard Encyclopedia of American Ethnic Groups. Cambridge, MA.: Harvard University Press, 1980. 


\section{NEWSPAPERS}

Daily Progress (New York)

Evening Star (New York)

Il Progresso Italo-Americano (New York)

L'eco d'Italia (New York)

La Voce del Popolo (San Francisco)

L'Italia (San Francisco)

L'Italo-Americano (New Orleans)

Rome (Denver)

The Daily Picayune (New Orleans)

The Herald (New York)

The New York Times (New York)

The Philadelphia Inquirer (Philadelphia)

The Rocky Mountain News (Denver)

The Seattle Press Times (Seattle)

The Tampa Daily Times (Tampa)

The Tampa Tribune (Tampa)

The Tribune (New York)

The Washington Post (Washington D.C.)

Trinacria (Pittsburg, Pa) 


\section{SECONDARY SOURCES}

\section{BOOKS}

Anderson, Benedict. Imagined Communities. Reflections on the Origins and Spread of Nationalism. 1983. Reprint, London: Verso, 1993.

Arias, Gino. La questione meridionale. Bologna: Zanichelli, 1970.

Ayers. Edward L. The Promise of the New South. New York: Oxford University Press, 1992.

Baines, Dudley. Emigration from Europe, 1815-1930. London: Cambridge University Press, 1991.

Bederman, Gail. Manliness and Civilization: A Cultural History of Gender and Race in the United States, 1880-1917. Chicago: University of Chicago Press, 1995.

Bezza, Bruno, ed. Gli italiani fuori d'Italia: Gli emigrati italiani nei movimenti operai dei loro paesi d'adozione (1880-1940). Milan: Franco Angeli, 1983.

Braudel, Ferdinand. The Mediterranean and the Mediterranean World in the Age of Philip II. New York: Harper \& Row, 1966.

Brundage, William F. Lynching in the New South: Georgia and Virginia, 18801930. Urbana: University of Illinois Press, 1993.

Cannistraro, Philip V. Blackshirts in Little Italy: Italian Americans and Fascism, 1923-1929. West Lafayette, Ind.: Bordighera, 1999.

Carano Donvito, Giovanni. L'economia meridionale prima e dopo il Risorgimento. Florence: Vallecchi, 1928.

Carpi, Leone. Dell'emigrazione italiana all'estero. Florence: Civelli, 1871.

Cassels, Alan. Mussolini's Early Diplomacy. Princeton: Princeton University Press, 1970.

Ciuffoletti, Zeffiro and Maurizio Degli Innocenti, eds. L'emigrazione nella storia d'Italia 1869-1975. Storia e documenti. 2 Vols. Florence: Vallecchi, 1978.

Corradini, Enrico. Discorsi Politici: 1902-1923. Florence: Vallecchi, 1923. 
Cutler, James E. Lynch-Law: An Investigation into the History of Lynching in the United States. New York: Arno Press, 1969.

Daniels, Roger. Coming to America. A History of Immigration and Ethnicity in America. New York: Harperperennial Library, 1990.

De Felice, Renzo. Interpretations of Fascism. Cambridge, MA: Harvard University Press, 1977.

De Grand, Alexander. Italian Fascism. Its Origins and Development. Lincoln, NE: University of Nebraska Press, 1982.

Devlin, Robert T. Commentaries on the Treaty Power under the Constitution of the United States. San Francisco: Bancroft-Whitney Co., 1908.

Di Scala, Spencer. Italy From Revolution to Republic, 1700 to Present. Oxford: Westview Press, 1995.

Divine, Robert A., et al. America Past and Present. 3rd ed. New York: Harper Collins, 1991.

Dore, Grazia. La democrazia italiana e l'emigrazione in America. Brescia: Morcelliana, 1964.

Dray, Philip. At the Hands of Persons Unknown: The Lynching of Black Americans. New York: Modern Library, 2003.

Ehrlich, Richard L., ed. Immigrants in Industrial America 1850 to 1920. Charlottesville: Published for the Eleutherian Mills-Hagley Foundation and the Balch Institute by University Press of Virginia,1977.

Felice, Costantino. II disagio di vivere. Il cibo, la casa, le malattie in Abruzzo e Molise dall'unità al secondo dopoguerra. Milan: Franco Angeli Collana Storia, n.128, 1989.

Foerster, Robert. The Italian Emigration of Our Times. 1919. Reprint, Cambridge, MA: Harvard University Press, 1924.

Franzina, Emilio. Dall'Arcadia in America. Attività letteraria ed emigrazione transoceanica in Italia 1850-1940. Turin: Fondazione Giovanni Agnelli, 1996.

Gabaccia, Donna R. Italy's Many Diasporas. London: University College Press, 2000. 
Gabaccia, Donna R. and Fraser M. Ottanelli, eds. Italian Workers of the World. Labor Migration and the Formation of Multiethnic States. Urbana: University of Illinois Press, 2001.

Gambino, Richard. Vendetta. Garden City, NY: Doubleday, 1977.

Garis, Roy L. Immigration Restriction: A Study of the Opposition to and Regulation of Immigration into the United States. New York: Macmillan, 1927.

Gramsci, Antonio. La questione meridionale. Rome: Editori Riuniti, 1970.

Grossi, Vincenzo. Questioni diplomatiche e coloniali. Rome: Tipografia Nazionale di Giovanni Bertero,1908

Guglielmo, Jennifer and Salvatore Salerno. Are Italians White? How Race is Made in America. New York: Routledge, 2003.

Handlin, Oscar. The Uprooted: The Epic Story of the Great Migrations that made the American People. Boston: Little, Brown, 1951.

Harney, Robert F. Selected Writings. Toronto: Multicultural History Society of Ontario, 1991.

Higham, John. Strangers in the Land: Patterns of American Nativism, 1860-1925. 1955. Reprint, New Brunswick: Rutgers University Press, 1988.

_ _ _ .Send These To Me: Immigrants in Urban America. Baltimore: Johns Hopkins University Press, 1984.

Hobsbawm, Eric. J. Nations and Nationalism since 1780. Cambridge, UK: Cambridge University Press, 1990.

Hoerder, Dick, ed. Labor Migration in the Atlantic Economies. The European in North American Working Classes During the Period of Industrialization. Westport, CT: Greenwood Press, 1985.

Hunt, Michael. Ideology and U.S. Foreign Policy. New Haven: Yale University Press, 1987.

Ingalls, Robert P. Urban Vigilantes in the New South: Tampa 1882-1936. Knoxville: University of Tennessee Press, 1988. 
Jacobson, Matthew Frye. Whiteness of a Different Color: European Immigrants and the Alchemy of Race. Cambridge, MA: Harvard University Press, 1998.

Jones, Maldwin Allen. American Immigration. Chicago: University of Chicago Press, 1960.

Korherr, Riccardo. Regresso delle nascite, morte dei popoli. Rome: Libreria del Littorio, 1928.

Lerda, Valeria Gennaro, ed. From Melting Pot to Multiculturalism. Rome: Bulzoni, 1990.

Lorenzoni, Giovanni. Inchiesta sulla piccola proprietà coltivatrice formatasi nel primo dopoguerra. Rome: Tipografia Operaia Romana, 1939.

Lucassen, Ian. Migrant Labor in Europe 1600-1900. London: Croon Helm, 1967.

Luconi, Stefano. La "diplomazia parallela:" II regime fascista e la mobilitazione politica degli italo-americani. Milan: Franco Angeli, 2000.

Luzzatto, Gino. L'economia italiana dal 1861 al 1894. Turin: Einaudi, 1968.

Manzotti, Ferdinando. La polemica sull'emigrazione nell'Italia unita.1962. Reprint, Milan: Società Editrice Dante Alighieri, 1969.

McNeil, William H. and Ruth S. Adams, eds. Human Migration: Patterns and Policies. Bloomington: Indiana University Press, 1970.

Mortara, Giorgio. Le popolazioni delle grandi città italiane. Turin: Unione Tipografica Editrice Torinese, 1908.

Moch, Leslie Page. Moving Europeans: Migration in Western Europe since 1650. Bloomington: Indiana University Press, 1992.

Nazzaro, Pellegrino. Fascist and Anti-Fascist Propaganda in America: The Dispatches of Italian Ambassador Gelasio Caetani. Youngstown, NY: Cambria Press, 2008.

Nevels Skove, Cynthia. Lynching to Belong: Claiming Whiteness Through Racial Violence. College Station, TX: Texas A\&M University Press, 2007.

Nitti, Francesco Saverio. Scritti sulla Questione Meridionale. Vol. I. Bari: Laterza,1958. 
Pozzetta, George E. Pane e Lavoro: The Italian American Working Class. Toronto: Multicultural History Society of Ontario, 1980.

Pozzetta George E. and Bruno Ramirez, eds. The Italian Diaspora: Migrations across the Globe. Toronto: Multicultural Cultural History Society of Ontario, 1992.

Pugliese, Enrico. L'Italia tra migrazioni internazionali e migrazioni interne. Atti del Congresso Internazionale per il XXI secolo. Dossier di ricerca. Volume II. Rome: Agenzia romana per la preparazione del Giubileo, 2002.

Rimanelli, Marco and Sheryl Postman, eds. The 1891 New Orleans Lynching and U.S.-Italian Relations: A Look Back. New York: Peter Lang, 1992.

Rosoli, Gianfausto, ed, Un secolo di emigrazione italiana, 1876-1976. Rome: Centro Studi Emigrazione, 1978.

Schlesinger Jr., Arthur M. The Disuniting of America. Reflections on a Multicultural Society. New York: W. W. Norton \& Co., 1992.

Serpieri, Arrigo. La struttura sociale dell'agricoltura italiana. Rome: Edizioni Italiane, 1947.

Simon, Julian L. and Ungar J.Sanford. The Economic Consequences of Immigration. Ann Arbor: University of Michigan Press, 1999.

Smith, Anthony D. Theories of Nationalism. New York: Holmes and Meir Publishers Inc., 1983.

_ _ _ . The Ethnic Origins of Nations. New York: Basil Blackwell, 1987.

Smith, Denis Mack. Italy: A Modern History. 1959. Reprint, Ann Arbor: The University of Michigan Press, 1969.

_ _ . Mussolini's Roman Empire. 1976. Reprint, New York: Penguin Books, 1977.

Sonnino, Sidney. Diario, 1866-1912. Bari: Laterza, 1972.

Sori, Ercole. Demografia Storica. Bologna: II Mulino, 1975.

_ _ _. L'emigrazione italiana dall'unità alla seconda guerra mondiale. Bologna: II Mulino, 1979. 
Tolnay, Stewart Emory. A Festival of Violence: An Analysis of Southern Lynchings, 1882-1930. Urbana: University of Illinois Press, 1995.

Tomasi, Silvano M. and Madeline H. Engel, eds. The Italian Experience in the United States. New York: Center for Migration Studies, 1970.

Vecoli, Rudolph J. and Susan Sinke, eds. A Century of European Migrations, 1830-1930. Urbana: University of Illinois Press, 1991.

Villari, Luigi. Italian Foreign Policy under Mussolini. New York: The DevinAdair Company, 1956.

Villari, Pasquale. Scritti sull'emigrazione e sopra altri argomenti vari. Bologna: Zanichelli, 1909.

Wells-Barnett, Ida B. On Lynchings: Southern Horrors, A Red Record, Mob Rule in New Orleans. New York: Arno Press, 1969.

White, Walter. Rope and Faggot. New York: Arno Press, 1969.

Yans-McLaughin, Virginia, ed. Immigration Reconsidered: History, Sociology, and Politics. New York: Oxford University Press, 1990.

\section{ARTICLES AND BOOK CHAPTERS}

Archdeacon, Thomas J. "Problems and Possibilities in the Study of American Immigration and Ethnic History." International Migration Review 19, no.1 (1985): 112-134.

Belleri Damiani, Claudia. "L'emigrazione italiana negli Stati Uniti durante il periodo fascista," in Affari Sociali Internazionali (special issue) (1978): 117-118.

Berthoff, Rowland T. "Southern Attitudes Towards Immigration, 1865-1914." Journal of Southern History XVII (1951): 322-336.

Bonelli, Franco. "Il capitalismo Italiano. Linee generali d'interpretazione," in Storia d'Italia. Annali I. Dal feudalismo al capitalismo. Turin: Einaudi, 1978.

Botein, Barbara. "The Hennessy Case: An Episode in Anti-Italian Nativism." Louisiana History: The Journal of the Louisiana Historical Association 20, no. 3 (1979): 261-279. 
Borchard, Edwin M. "The Law of Responsibility of the States in their Territory to the Person or Property of Foreigners." The American Journal of International Law, 23, 2 Supplement Codification of International Law (April 1929): 131-239.

Cannistraro, Philip V. "Fascism and Italian Americans." in Silvano M. Tomasi, ed. Perspectives in Italian Immigration and Ethnicity. New York: Center for Migration Studies, 1977: 51-66.

Cannistraro, Philip and Gianfausto Rosoli, "Fascist Emigration Policy in the 1920s: An Interpretive Framework." International Migration Review, 13, no. 4 (1979): 673-692.

De Michelis, Giuseppe. "L'emigrazione italiana dal 1910 al 1923." Rome: CGE, 1926.

Diggins, John P. "The Italo-American Anti-Fascist Opposition." Journal of American History 54, no.3 (1967): 580-590.

Earl, Philip I. "Nevada's Italian War." Nevada Historical Society Quarterly, XII, no.2 (1969): 47-87.

Fabiano, Domenico. "I fasci italiani all'estero." In Gli italiani fuori d'Italia, Bezza ed.: 221-236.

Fava, Francesco Saverio. "I linciaggi negli Stati Uniti. La questione giuridica." Nuova Antologia vol. 97 (1902): 642-649.

Ferraris, Carlo. "Il movimento generale dell'emigrazione italiana: suoi caratteri ed effetti." Bollettino dell'emigrazione no. 5 Rome: Tipografia Nazionale di G. Bertero, 1909.

Gabaccia, Donna. "Italian History and gli Italiani nel Mondo, Part I." Journal of Modern Italian Studies vol. 2, no. 1 (1997): 45-66.

Gammans, Nelson. "The Responsibility of the Federal Government for Violations of the Rights of Aliens." The American Journal of international Law 8, 1 (January 1914): 73-80.

Goebel, Julius Jr. "The International Responsibility of States for Injuries Sustained by Aliens on Account of Mob Violence, Insurrections and Civil Wars." The American Journal of International Law 8, 4 (Oct. 1914): 802-852.

Harney, Robert F. "The Commerce of Migration." Canadian Ethnic Studies XI, 1 (1977): 42-53. 
Higham, John. "Immigration." In C.V. Woodward, The Comparative Approach to American History. New York: Basic Books, 1968: 91-105.

_ _ - "Integrating America: The Problem of Assimilation in the Nineteenth Century." Journal of American Ethnic History 1 (1981): 7-25.

_ - - "Current Trends in the Study of Ethnicity in the United States." Journal of American Ethnic History 2 (1982): 5-15.

Hixson, William B., Jr. "Moorfield Storey and the Defense of the Dyer AntLynching Bill." The New England Quarterly 42, 1 (March 1969): 65- 81.

Jackson, James H. and Leslie Page Moch. "Migration and the Social History of Modern Europe" Historical Methods 22 (1989): 27-36.

Jackson, Joy. "Crime and the Conscience of a City." Louisiana History. The Journal of the Louisiana History Association 9, 3 (Summer, 1968): 229-244.

Leonard, Henry B. "American Immigration. An Historiographical Essay." Ethnic Forum 8 (1988): 9-23.

Lee, Thomas H. "The Supreme Court of the United States as QuasiInternational Tribunal Reclaiming the Court's Original and Exclusive Jurisdiction OverTreaty-Based Suits by Foreign States against States." The Columbia Law Review (November 2004): 1765-1885.

Lodge, Henry Cabot. "Lynch Law and Unrestricted Immigration," North American Review 152 (1891): 602-612.

_ _ _. "Italy's Attitude Toward Her Immigrants." North American Review (1905): 720-726.

Mayor de Planches, Edmondo. "Nel Sud degli Stati Uniti." Nuova Antologia vol. 206 (March 1, 1906): 3-30.

Montagna, Francesco. "Relazione della Giunta del bilancio sugli stati di previsione del Fondo per l'emigrazione per l'eservcizio 1907-08." Bollettino dell'emigrazione no. 5 Rome: Tipografia Nazionale di G. Bertero, 1908.

Moroni, Gerolamo. "L'emigrazione italiana nel distretto consolare di New Orleans." Bollettino dell'emigrazione, no. 16. Rome: Tipografia Nazionale di G. Bertero, 1908. 
Nathan, Ernesto. "Di un disegno di colonizzazione." Nuova Antologia vol. 110 (1904): 537-542.

Nazzaro, Pellegrino. "Italy from the American Immigration Quota Act of 1921 to Mussolini's Policy of Grossraum 1921-1924," in The Journal of European Economic History 3 (1974): 705-723.

Nobile, Annunziata. "Politica migratoria e vicende dell'emigrazione durante il fascismo." II Ponte XXX (November-December 1974): 1322-1335.

Olzak, Susan," The Political Context of Competition: Lynching and Urban Racial Violence, 1882-1914." Social Forces 69, 2 (Dec., 1990): 395-421.

Pozzetta, George E. "Italians and the Italian General Strike of 1910." in Pane e Lavoro: The American Working Class. Toronto: Multicultural History Society of Ontario, 1980.

_ _ - "Immigrants and Ethnics: The State of Italian-American Historiography." Journal of American Ethnic History 9, 1 (Fall 1989): 67-95.

Romano, Ruggero. "Una tipologia economica," in Storia d'Italia. vol. I. Turin: Einaudi, 1972.

Rosmini, Carlo. "Il nuovo progetto sull'emigrazione." in I/ Giornale degli Economisti, III (1888): 121-174.

Rossi, Adolfo. "Per la tutela degli Italiani negli Stati Uniti." Bollettino della 'Emigrazione. Rome:Tipografia Nazionale di G. Bertero, 1904.

Saudino, Domenico. "Il movimento fascista tra gli Italiani d'America." La parola del popolo 9 (December 1958-January 1959): 69-79.

Salerno, Aldo. "America for Americans Only: Gino C. Speranza and the Immigrant Experience." Italian Americana 14 (Summer 1996): 133-147.

Smith, Timothy. "New Approaches to the History of Immigration in 20thCentury America." American Historical Review 71 (July 1966): 1265-1279.

Sonnino, Eugenio. "Problemi di metodo e primi risultati di una ricerca sullo spopolamento dei comuni italiani dopo l'Unità." in Ercole Sori, ed. Demografia Storica. Bologna, II Mulino, 1975. 
Sori, Ercole. "Emigrazione all'estero e migrazioni interne in Italia fra le due guerre." Quaderni Storici X (1975): 579-606.

Venturini, Nadia. "Le comunità italiane negli Stati Uniti fra storia sociale e storia politica." Rivista di storia contemporanea 2 (April 1984): 202-220.

Viazzo, Pier Paolo and Dionigi Albera. "La famiglia contadina nell'Italia settentrionale 1750-1930," in Marzio Barbagli and David I. Kertzner, eds. Storia della famiglia italiana, 1750-1950. Bologna: II Mulino, 1992.

Villari, Luigi. "L'opinione pubblica americana e i nostri emigrati." Nuova Antologia vol. 148 (1910): 497-517.

Villari, Pasquale. "L'emigrazione e le sue conseguenze in Italia." Nuova Antologia, vol. 127 (1907): 35-56.

Walter, David O. "Legislative Notes and Review Proposals for a Federal AntiLynching Law." The American Political Science Review 28, no. 3 (1934): 436-442.

Watson, Charles H. "Need of Federal Legislation in Respect to Mob Violence in Cases of Lynching of Aliens. The Yale Law Journal 25, no. 7 (1916): 561-581.

Woodall, Conrad. "The Italian Massacre at Walsenburg, Colorado, 1895." In Italian Ethnics: Their Languages, Literature and Lives. Proceedings of the 20th Annual Conference in the American Historical Association. Chicago, Illinois, November 11-13, 1987: 297-317. Staten Island: American Italian Historical Association, 1990.

\section{DISSERTATIONS}

Catino, Martin Scott. "Mussolini's March on America: Italian Americans and the Fascist Experience, 1922-1941." Ph.D. Dissertation, University of Southern Mississippi, 2003. 